Kátia Freire da Silva

Sapindaceae na Serra do Cipó, Minas Gerais, Brasil.

Sapindaceae at Serra do Cipó, Minas Gerais, Brasil.

São Paulo 
Kátia Freire da Silva

Sapindaceae na Serra do Cipó, Minas Gerais, Brasil.

Sapindaceae at Serra do Cipó, Minas Gerais, Brasil.

Dissertação apresentada ao Instituto de Biociências da Universidade de São Paulo, para a obtenção de Título de Mestre em Botânica, na Área de Sistemática, Evolução e Biogeografia de Plantas Vasculares.

Orientador: Dr. Milton Groppo

São Paulo

2011 
Silva, Kátia Freire da

Sapindaceae na Serra do Cipó, Minas

Gerais, Brasil.

148 pgs.

Dissertação (Mestrado) - Instituto de Biociências da Universidade de São Paulo.

Departamento de Botânica.

1. Sapindaceae 2. Flora 3. Serra do

Cipó

I. Universidade de São Paulo. Instituto de

Biociências. Departamento de

Botânica.

Comissão Julgadora:

$\operatorname{Prof}(a) \cdot \operatorname{Dr}(a)$.

$\operatorname{Prof}(a)$. Dr(a).

Prof. Dr. Milton Groppo

orientador 
Aos amantes e admiradores da vida... 
O esclarecimento é como a lua refletida na água.

A lua não se molha nem a água se rompe.

Embora a lua seja vasta e intensa, pode refletir-se até mesmo numa poça de tamanho ínfimo.

A lua e o céu estão refletidos nas gotas de orvalho sobre a relva ou até mesmo numa gota de água. O esclarecimento não vos divide, assim como a lua não rompe a água. Não podeis impedir o esclarecimento, assim como uma gota de água não impede a lua no céu.

Mestre Dögen (trad. Kazuaki Tanahashi) 


\section{Agradeço...}

A CAPES, pela bolsa concedida para a realização deste trabalho.

Ao Programa de Pós Graduação em Botânica da USP, pela oportunidade do mestrado.

A minha família exemplo de força, pelo o amor, confiança e admiração que sempre me dedicaram.

Ao meu amor Renato sempre tão companheiro, fundamental nos meus primeiros passos na Botânica, pela compreensão, paciência, pelo sacrifício de tolerar minha ausência, pela sua paixão pelas árvores, pelos tantos momentos especiais e pelo patrocínio, por tornar possível a realização deste trabalho.

Ao prof. Dr. Milton Groppo pela paciência e confiança, pelo respeito as minhas limitações e meu ritmo, pelo apoio e incentivo constantes, pelo exemplo de profissional, pela amizade e principalmente pela orientação.

Ao Laboratório de Sistemática Vegetal da Faculdade de Filosofia, Ciências e Letras de Ribeirão Preto, USP, pelo uso de suas instalações, à Maria Helena, sua técnica, pela atenção, disposição, competência e pelos momentos de descontração.

Ao prof. Dr. José Rubens Pirani, pelas valiosas sugestões, pelo exemplo de profissional, pela dedicação e competência, por tornar possível a realização deste trabalho.

A profa. Dra. María Silvia Ferrucci, pelo carinho, pela predisposição em colaborar com o trabalho, pela sua dedicação em compartilhar comigo todo o seu precioso conhecimento sobre a família Sapindaceae, pela suas acuradas correções, pelo apoio e amizade, por me apresentar os deliciosos alfajores bonafide.

Ao Dr. Pedro Acevedo-Rodríguez pela atenção, carinho e pelas valiosas sugestões. 
A profa. Dra. Inês Cordeiro, por me despertar o interesse em taxonomia e sistemática, pela dedicação, pelo exemplo profissional de pesquisadora, pelos ótimos conselhos.

Ao Parque Nacional da Serra do Cipó, pela licença de coleta, acomodações e ótimo atendimento. Ao Henri Collet (diretor do Parque) e aos funcionários, Celso, Vicente, Lecínio e família, Mônica e Josiane, pela recepção, boa vontade e ajuda nos trabalhos de campo.

A família cidade do circo, pelo exemplo de vida, por me enfeitiçarem com a magia do circo e dividirem comigo tanta simplicidade, superação e risos... muitos.

Aos mamutes pela amizade e pelos muitos momentos especiais.

Ao Norberto secretário da Pós-Graduação da Botânica, pelo exemplo profissional, sempre prestativo e disposto.

Aos colegas do laboratório de Sistemática Vegetal, Mario, João Paulo, Tati, Tanaka, Tropeço, Rafael, Luziene e Gabriela, pelo apoio, pelas sugestões e discussões e por tudo que acrescentaram nesse trabalho e na minha vida. A Carlinha pelos momentos de descontração, amizade e por estar presente e me ajudar em alguns momentos difíceis.

As bibliotecárias do acervo de obras raras pela paciência, simpatia e principalmente, pela ética profissional e atenção.

Aos pesquisadores e curadores dos herbários BHCB, CTES, ESA, R, SP, SPF e UEC, pela atenção e pelo empréstimo ou doações de materiais, em especial ao Prof. Alexandre Salino por ter me disponibilizado as suas instalações e a Profa. Dra. María Mercedes Arbo, pelo apoio durante a minha estada em sua respectiva instituição.

Aos Biólogos e ilustradores Maíra Clasen Massarani e Bruno Garcia Simões Favaretto pela dedicação na confecção das ilustrações das espécies.

As amigas, tia Miriam e Le que me acolheram com muito carinho em suas casas no período em que eu já não estava mais morando em Ribeirão Preto. 


\section{Índice}

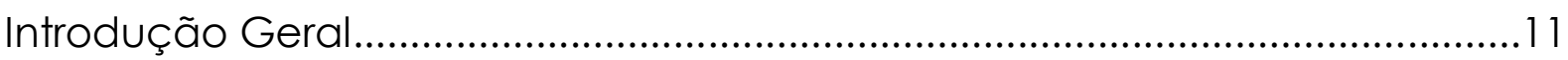

1.A família Sapindaceae.............................................................................11

2.Projeto Flora da Serra do Cipó e ocorrência do grupo estudado...............16

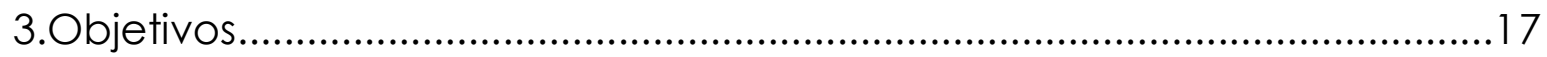

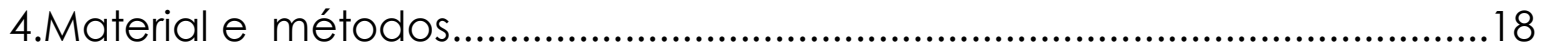

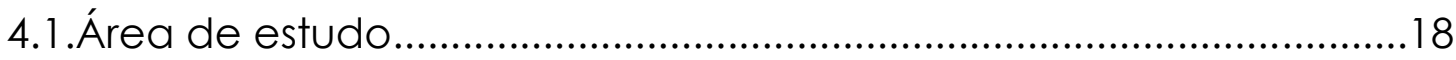

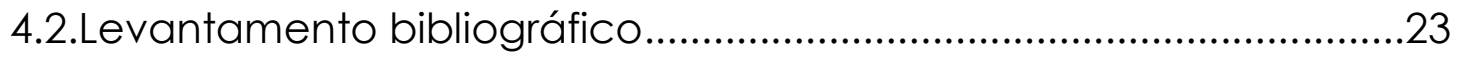

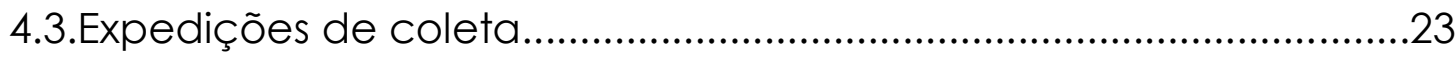

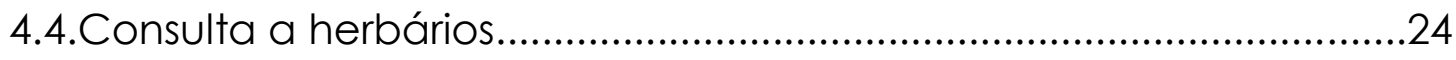

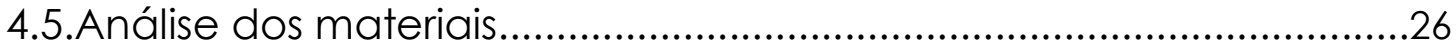

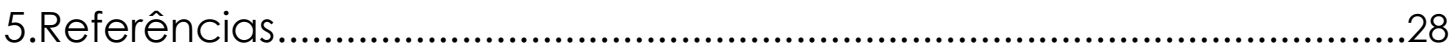

CAPÍTULO 1. Flora da Serra do Cipó, Minas Gerais: Sapindaceae.....................36

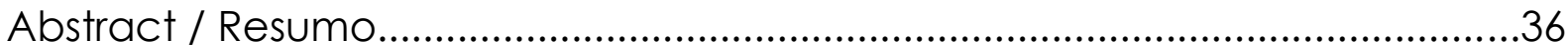

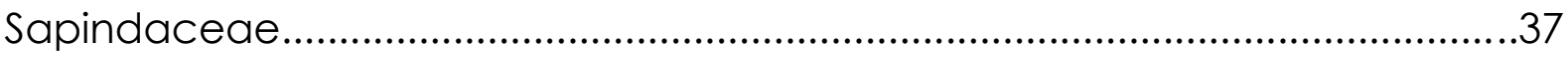

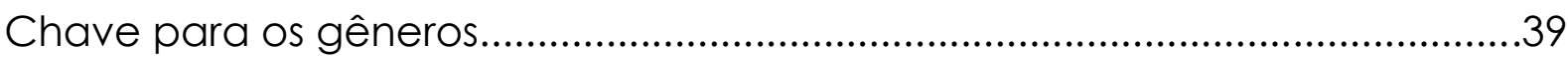

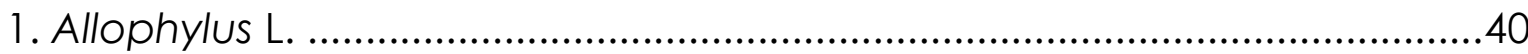

Chave para as espécies de Allophylus..........................................................41

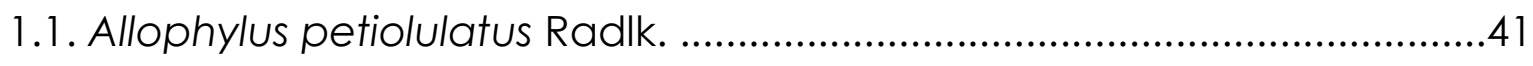

1.2. Allophylus sericeus (Cambess.) Radlk..............................................43

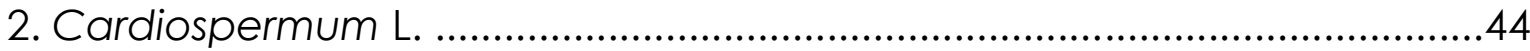

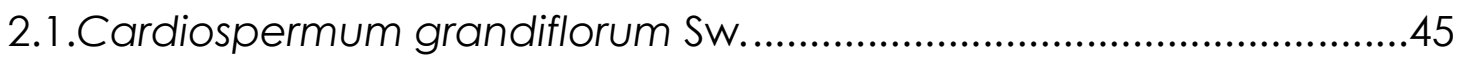

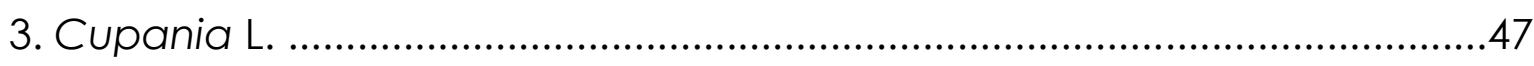

Chave para as espécies de Cupania ...........................................................48

3.1. Cupania ludowigii Somner \& Ferrucci................................................49

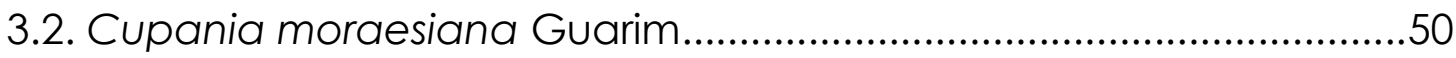


3.3. Cupania paniculata Cambess. .52

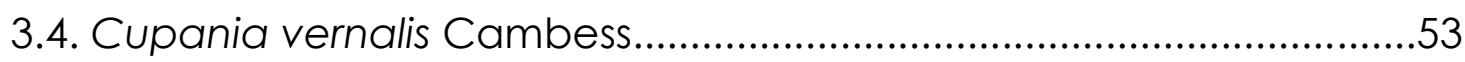

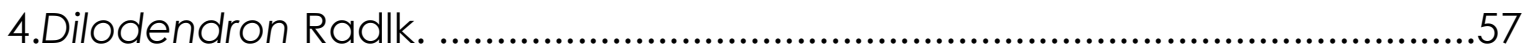

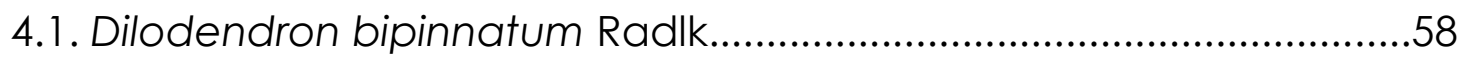

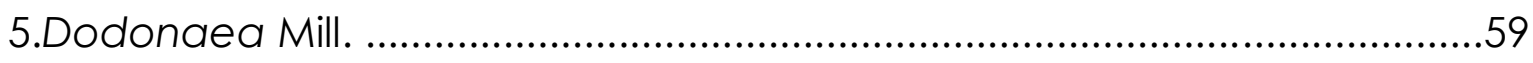

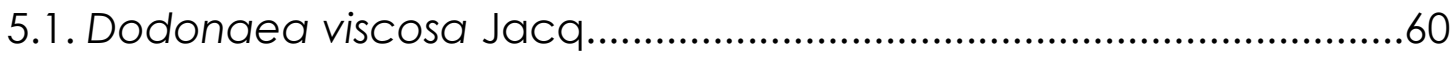

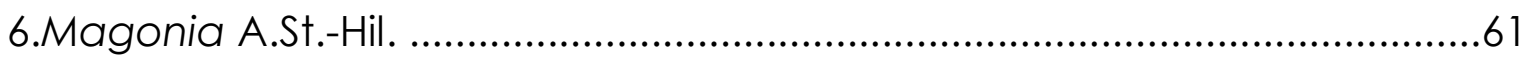

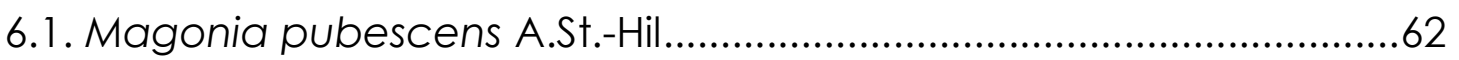

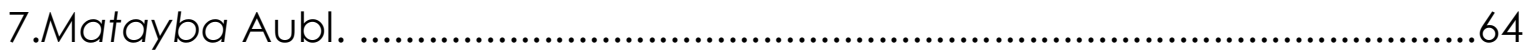

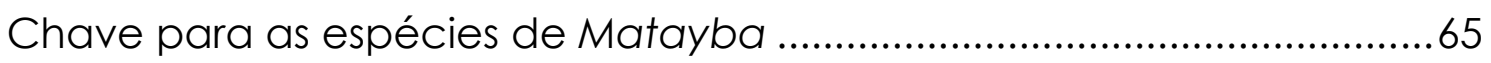

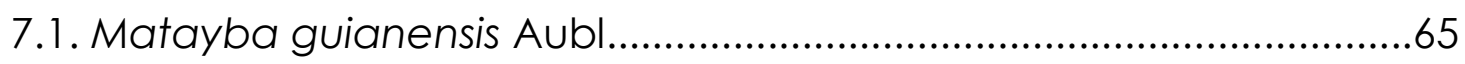

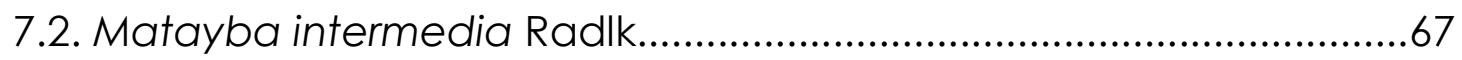

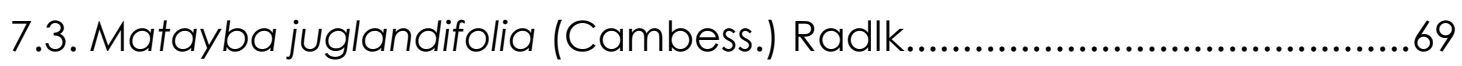

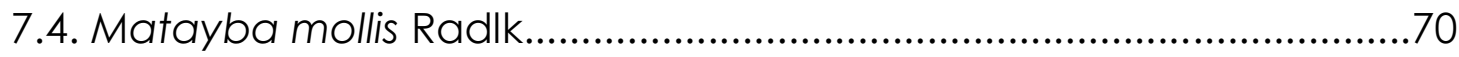

7.5. Matayba stenodictya Radlk.............................................................72

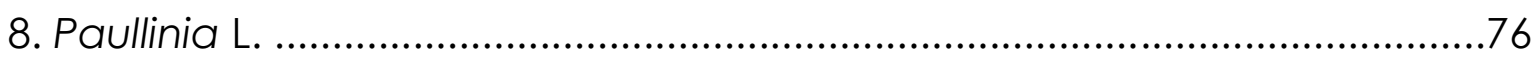

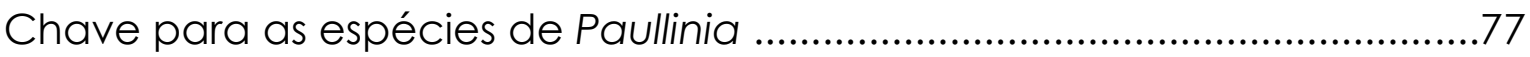

8.1. Paullinia carpopoda Cambess............................................................77

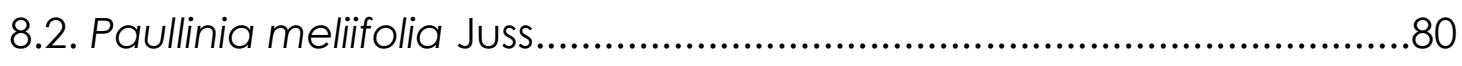

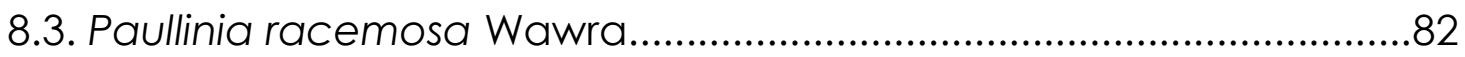

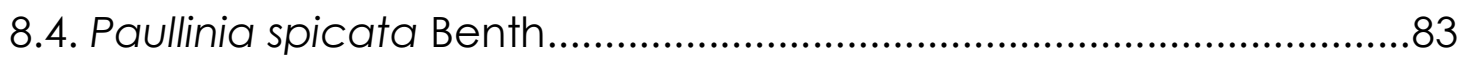

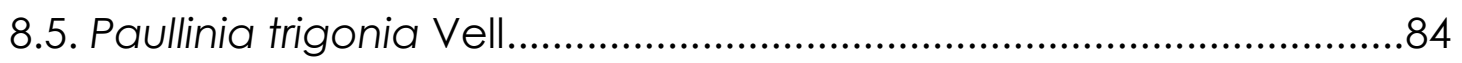

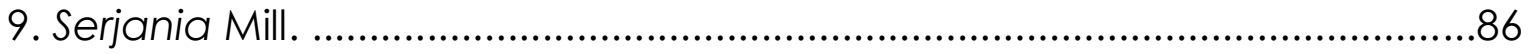

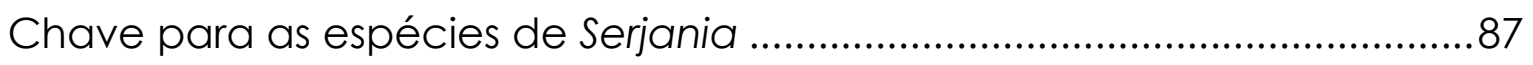

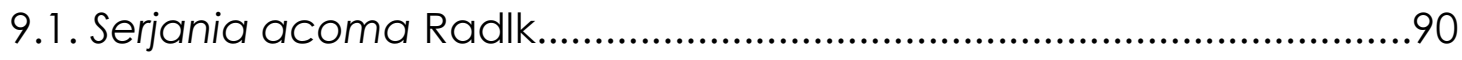

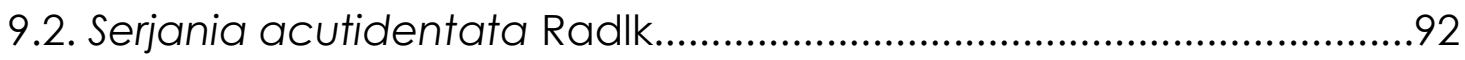

9.3. Serjania caracasana (Jacq.) Willd.........................................................94

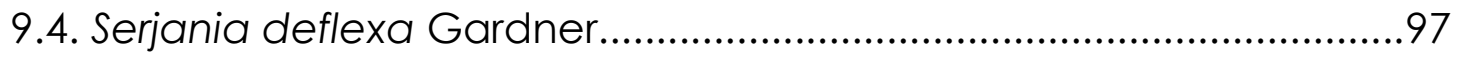

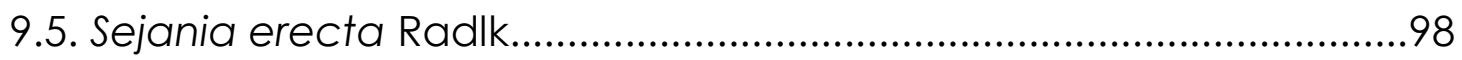

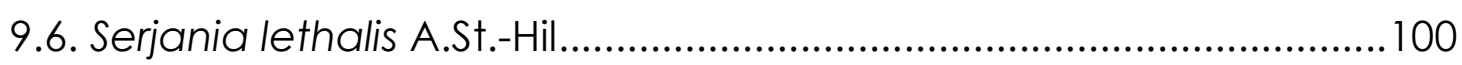

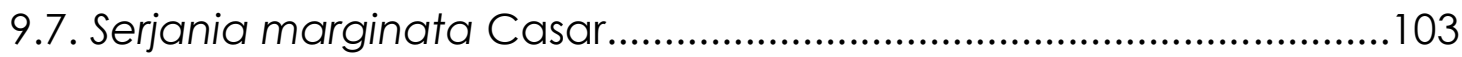

9.8. Serjania multiflora Cambess..............................................................105 


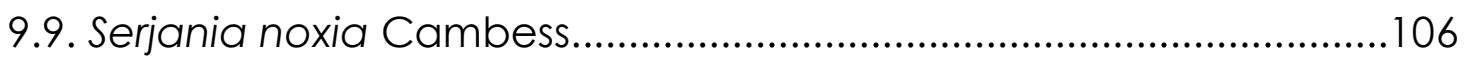

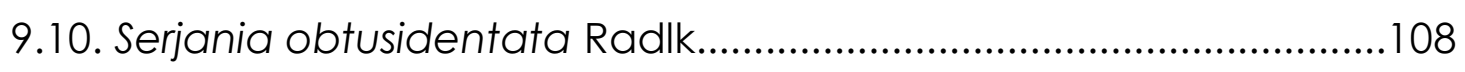

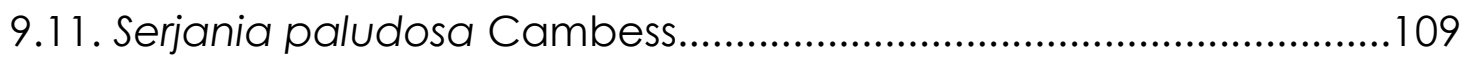

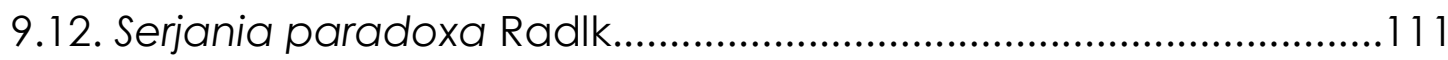

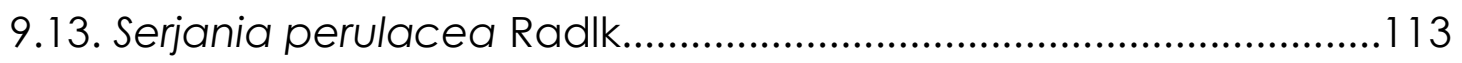

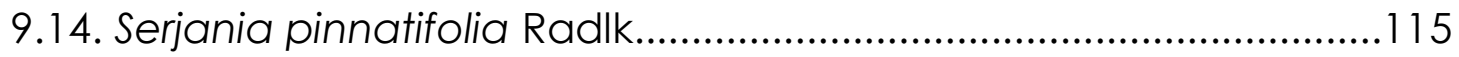

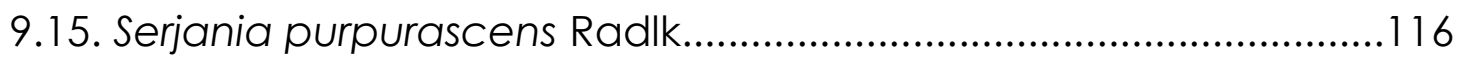

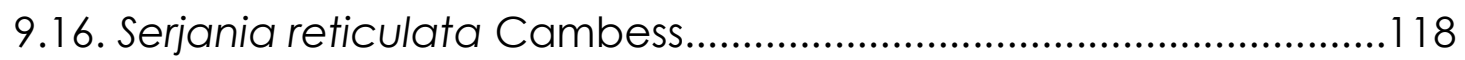

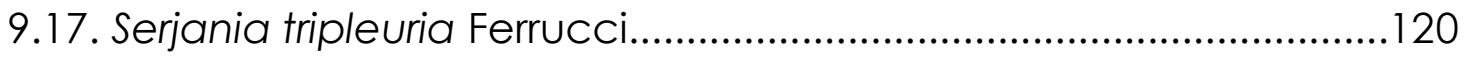

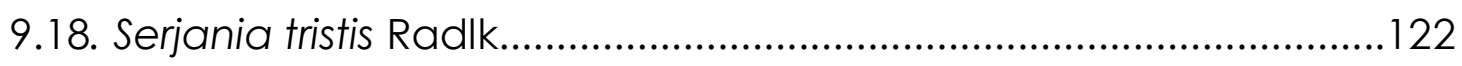

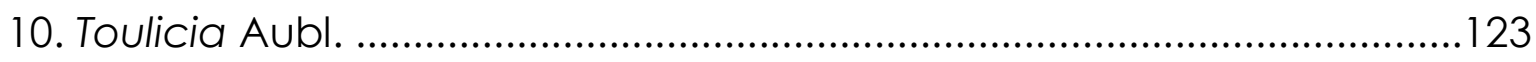

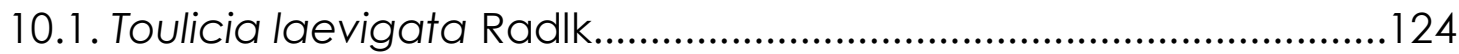

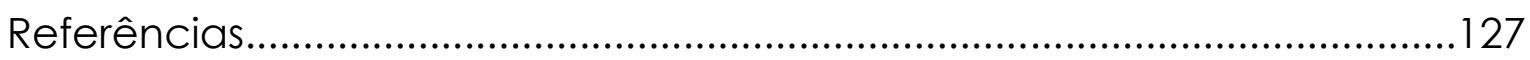

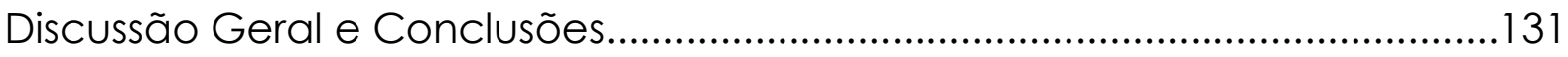

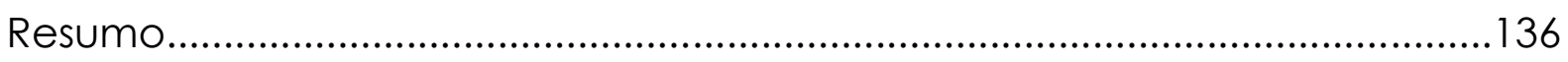

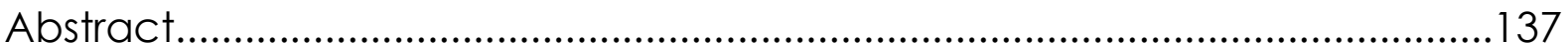

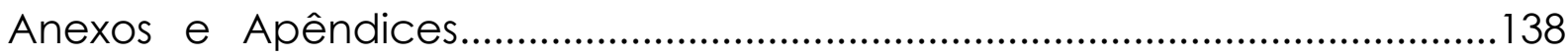

\section{Índice de figuras e tabelas}

Introdução Geral

Figura 1- A, filogenia baseada em Máxima Verossimilhança para Sapindaceae s.lat.; B, relações filogenéticas entre e dentro de Aceraceae e Hippocastanaceae; C, relações na subfamília Dodoneoideae.

Figura 2- Localização da Cadeia do Espinhaço, com os topônimos principais e destaque para a Serra do Cipó, Minas Gerais. 
Figura 3- Localização da região da Serra do Cipó, com limites dos municípios e das duas unidades de conservação federais: Parque Nacional da Serra do Cipó e APA Morro da Pedreira. .22

Capítulo 1

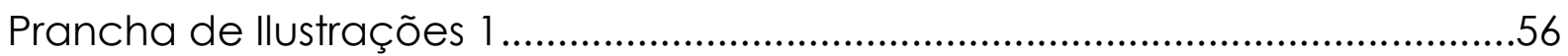

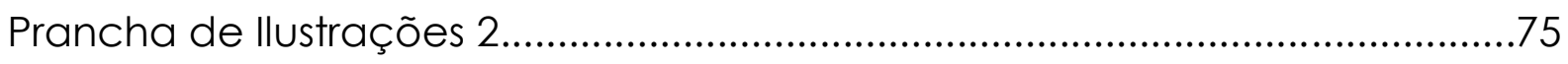

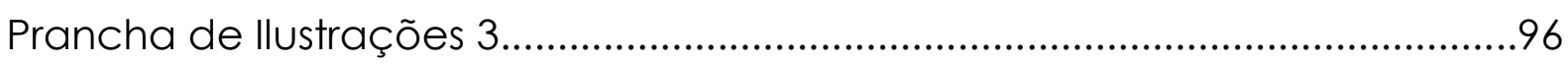

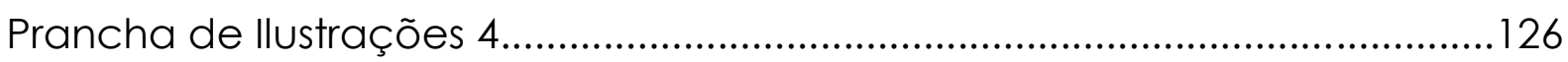

Anexos e Apêndices

Tabela 1 - Relação das espécies de Sapindaceae registradas nas principais fitofisionomias, porções Leste ou Oeste e gradiente altitudinal na Serra do Cipó...... 139

Tabela 2. Relação das espécies arbóreas de Sapindaceae registradas nas 18 áreas de formações florestais inventariadas no Complexo do Espinhaço em Minas Gerais e Bahia. 141

Figura 4- Espécies de Sapindaceae na Serra do Cipó......................................142

Figura 5- Espécies de Sapindaceae na Serra do Cipó........................................143

Figura 6- Espécies de Sapindaceae na Serra do Cipó......................................144

Figura 7- Espécies de Sapindaceae na Serra do Cipó......................................145

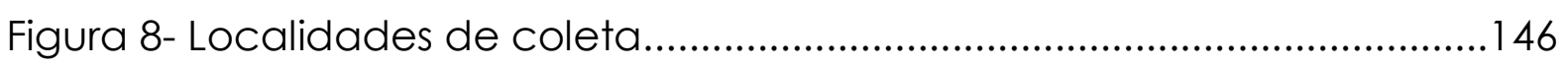

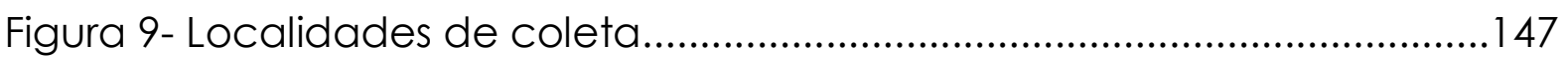

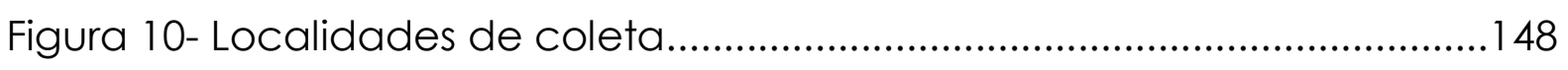




\section{Introdução Geral}

\section{A família Sapindaceae}

A família Sapindaceae s.l. está incluída na ordem Sapindales (Eudicotiledôneas), juntamente com mais 8 famílias: Anacardiaceae, Biebersteiniaceae, Burseraceae, Kirkiaceae, Nitrariaceae (incluindo Peganaceae e Tetradiclidaceae), Rutaceae, Meliaceae e Simaroubaceae (APG II, 2003, APG III, 2009, Judd et al., 2008, Soltis et al., 2005), possui 471 gêneros e 6070 espécies (Stevens, 2011), sendo uma das maiores ordens de angiospermas em termos de números de gêneros e espécies (Gadek et al., 1996).

A ordem Sapindales apresenta-se como um clado bem suportado após estudos moleculares com análises de seqüências baseadas em rbcL, atpB e 18 (Chase et al., 1993, Gadek et al., 1996, Soltis et al., 2005, Judd et al., 2008), sinapomorfias não moleculares para o clado não são tão claras (Soltis et al., 2005). Diversos caracteres são amplamente distribuídos na ordem como plantas lenhosas, folhas pinado-compostas (às vezes palmadocompostas, trifoliadas ou unifoliadas), sem estípulas, flores em geral pequenas, tetra ou pentâmeras, disco nectarífero distinto e as partes florais imbricadas (Soltis et al., 2005).

Segundo Kubitzki (2011), a ordem Sapindales é uma linhagem antiga com registro fóssil que remonta ao Cretáceo. É provável que a rápida evolução de Sapindales ocorreu na América do Norte, e que, no Eoceno se dispersaram para o leste através do cinturão temperado-quente do norte do Mar de Tétis e de lá invadiram e se diversificaram em regiões tropicais.

A família Sapindaceae s.s. compreende ca. 1756 espécies e 136 gêneros. No Brasil está representada por 25 gêneros e ca. 411 espécies, 187 são endêmicas (Somner et al., 2010). Possui uma distribuição predominantemente pantropical com ocorrência de alguns táxons em áreas temperadas (e.g. Acer, Aesculus, Atalaya, Diplopeltis, Dodonaeae) (Buerki ef 
al., 2009). Seu maior gênero é Serjania (220 spp.) seguido de Paullinia (150), Acer (110) e Allophylus (100) (Judd et al., 2008). As espécies podem ser encontradas em diversos ambientes e tipos vegetacionais.

O clado formado pela família Sapindaceae s.l., de acordo com Judd et al. (2008) possui como principais sinapomorfias: aminoácidos de ciclopropano, pétalas apendiculadas, estames 8 ou menos, filetes pubescentes ou papilosos, óvulos sésseis, flores com disco nectarífero extraestaminal e embrião curvo com dobra na testa. Pode-se citar as sementes frequentemente ariladas e para algumas espécies de trepadeiras destacam-se ainda o exsudado geralmente branco e o caule com crescimento secundário anômalo.

O potencial econômico da família Sapindaceae é altamente significativo. Em um trabalho etnobotânico, Guarim-Neto et al. (2000), catalogaram 52 espécies distribuídas em 17 gêneros, com formas de usos diferenciadas, incluindo as plantas com potencial ornamental além da madeira, raízes, cascas do caule e dos ramos, folhas, frutos, sementes e a seiva. Entre os representantes podem ser citados o guaraná (Paullinia cupana), a lichia (Litchi chinensis), a pitomba (Talisia esculenta), o longan ou olho-de-dragão (Dimocarpus longan) e o rambotão (Nephelium lappaceum) com frutos comestíveis (Souza \& Lorenzi, 2005, Buerki et al., 2009). O fruto de Sapindus saponaria (sabão-de-soldado) pode ser usado como sabão devido à presença de saponinas (Souza \& Lorenzi, 2005, Judd et al. 2009). Como ornamentais Koelreuteria e Ungnadia (Buerki et al., 2009).

A circunscrição da família sapindaceae bem como os relacionamentos infrafamiliar tem sido amplamente contestados (Harrington et al., 2005, Buerki et al., 2009), particularmente com considerações para inclusão de gêneros relacionados, predominantemente as famílias temperadas Aceraceae e Hippocastanaceae (Harrington et al., 2005). Na primeira classificação proposta por Jussieu (1789), Sapindaceae está como uma família distinta de Aceraceae. Já Bentham \& Hooker (1862) incluíram Aceraceae e Hippocastanaceae dentro de Sapindaceae. 
Radlkofer (1892-1900, 1933-1934) realizou o primeiro e mais completo tratamento taxonômico, e forneceu o primeiro sistema de classificação mundial da família Sapindaceae. Ele dividiu Sapindaceae em duas subfamílias (Sapindoideae e Dodoneoidaeae) e 14 tribos, e colocou-a como família distinta de Aceraceae e Hippocastanaceae. Suas obras são amplamente utilizadas até os dias atuais e ponto de partida para os estudos com a família.

Os trabalhos de Takhtajan (1981, 1997), Cronquist (1988), e Dahlgren (1989) baseados em morfologia e biogeografia, mantiveram Aceraceae e Hippocastananceae como famílias separadas de Sapindaceae.

O conceito amplo da família tem sido adotado nos trabalhos de macromorfologia e palinologia (Muller \& Leenhouts, 1976), análise cladística com matriz morfológica (Judd et al., 2002) e dados moleculares (Thorne, 2007, Gadek et al., 1996, APG II, 2003, APG III, 2009, Savolainen et al., 2000, Soltis et al., 2005), os quais rearrajaram algumas subfamílias e tribos reconhecidas por Radlkofer (1892-1900).

Harrington et al. (2005), publicaram a primeira filogenia molecular de Sapindaceae s.l. utilizando sequência de DNA de matK e rbcL, onde sugerem a divisão da família em 4 subfamílias e 14 grupos: Xanthoceroideae, Hippocastanoideae (2 grupos); Dodonaeoideae (2 grupos) e Sapindoideae (10 grupos) e destacam a parafilia e a polifilia de diversas tribos.

Buerki et al. (2009), apresentaram uma análise filogenética de Sapindaceae s.l. baseada em sequências de DNA de 8 regiões de plastídeos e genoma nucleares e incluindo 85 dos 141 gêneros, seus resultados indicam alto nível de parafilia e polifilia das subfamílias e tribos, confirmam que o gênero monotípico Chinês Xanthoceras é irmão de todo o resto da família e propõem grupamento informais como base para uma nova classificação de Sapindaceae s.l.

Buerki et al. (2010), em seu trabalho mais recente de filogenia utilizando 243 amostras representando 104 dos 142 gêneros reconhecidos de Sapindaceae s.l., através de sequência de dados analizadas com os marcadores (ITS e matK, rpoB, trnD-trnT, trnK-matK, trnL-trnF e trnS-trnG), 
confirmam a consistência de Sapindaceae s.l. adotada por diversos autores (APG II, APG III, Harrington et al., 2005, Buerki et al., 2009), entretanto apontam a presença de diversos problemas conceituais na circunscrição ampla da família Sapindaceae e concluem manter Aceraceae, Hippocastanaceae e Sapindaceae s.s. (excluindo Xanthoceras) como entidades morfologicamente e biogeograficamente separadas qual tem sido reconhecidas por mais de um século, e a fim de tornar Sapindaceae s.s. monofilética, propõem colocar Xanthoceras em uma nova monotípica família, Xanthoceraceae.

Dessa maneira, a atual circunscrição da família Sapindaceae s.s., se assemelha ao proposto por Radlkofer (1892-1900, 1933-1934), a mantendo distinta de Aceraceae e Hippocastanaceae (fig. 1). Xanthoceras sorbifolium Bunge foi excluída de Sapindaceae, agora pertencente a uma nova família monotípica Xanthoceraceae, sendo irmã do clado que compreende Sapindaceae, Aceraceae e Hippocastancaea (fig. 1).

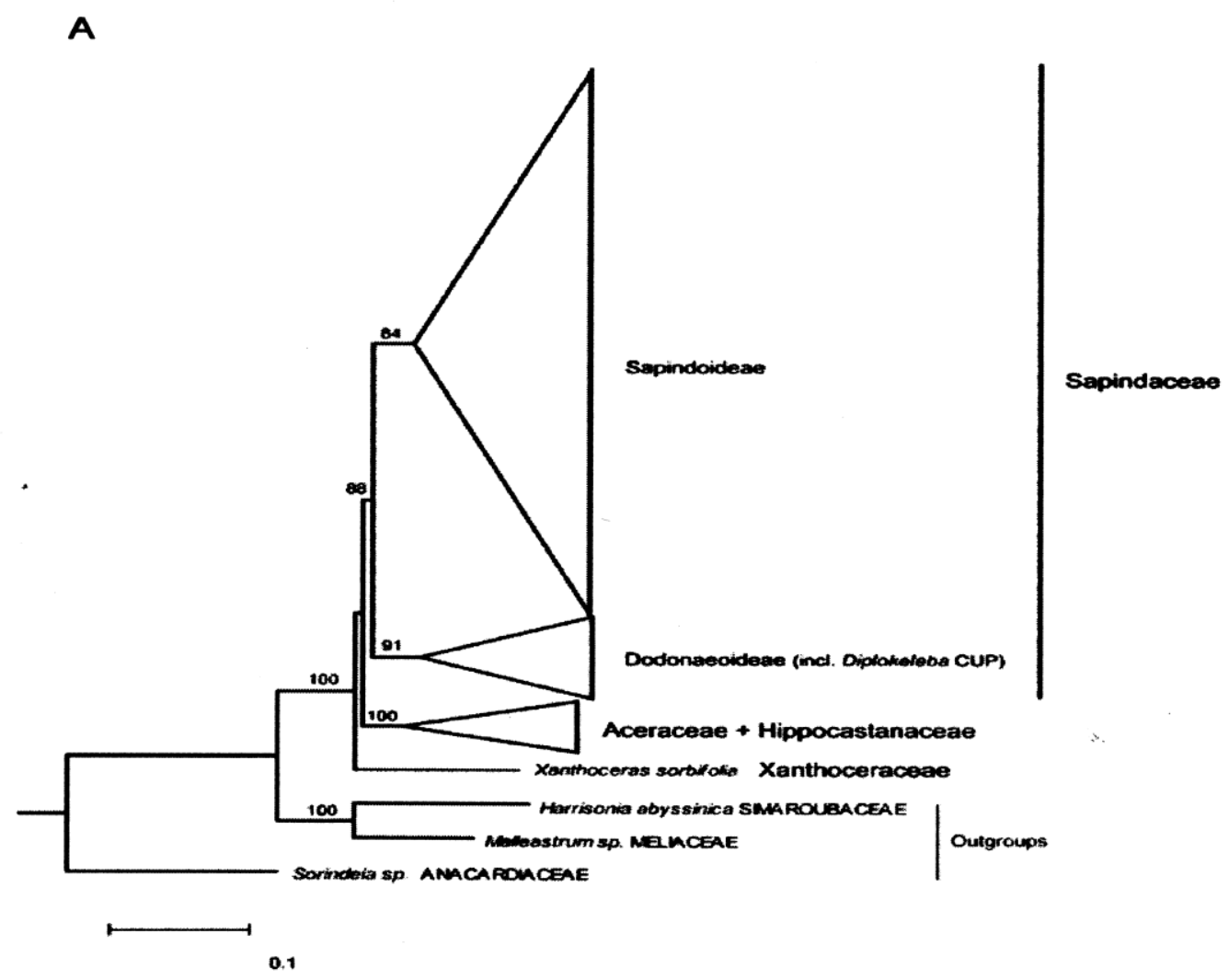


B
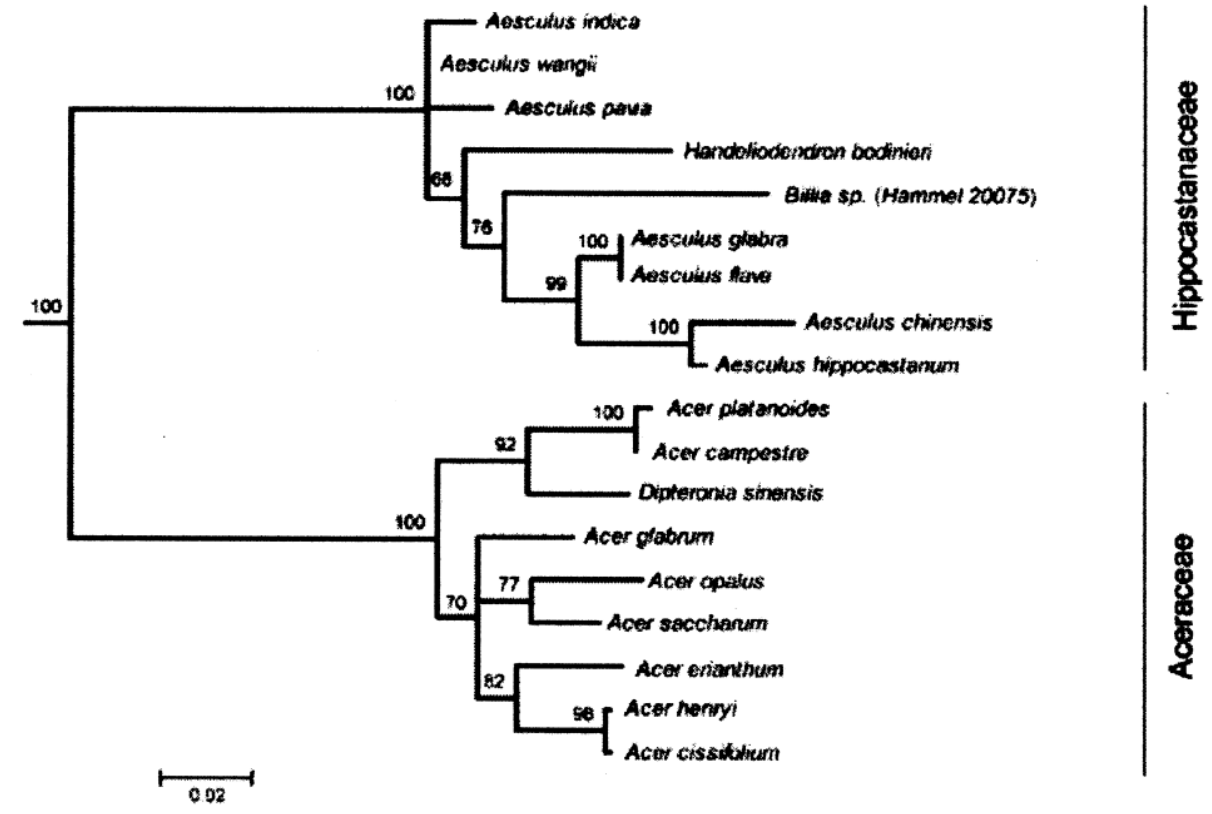

C

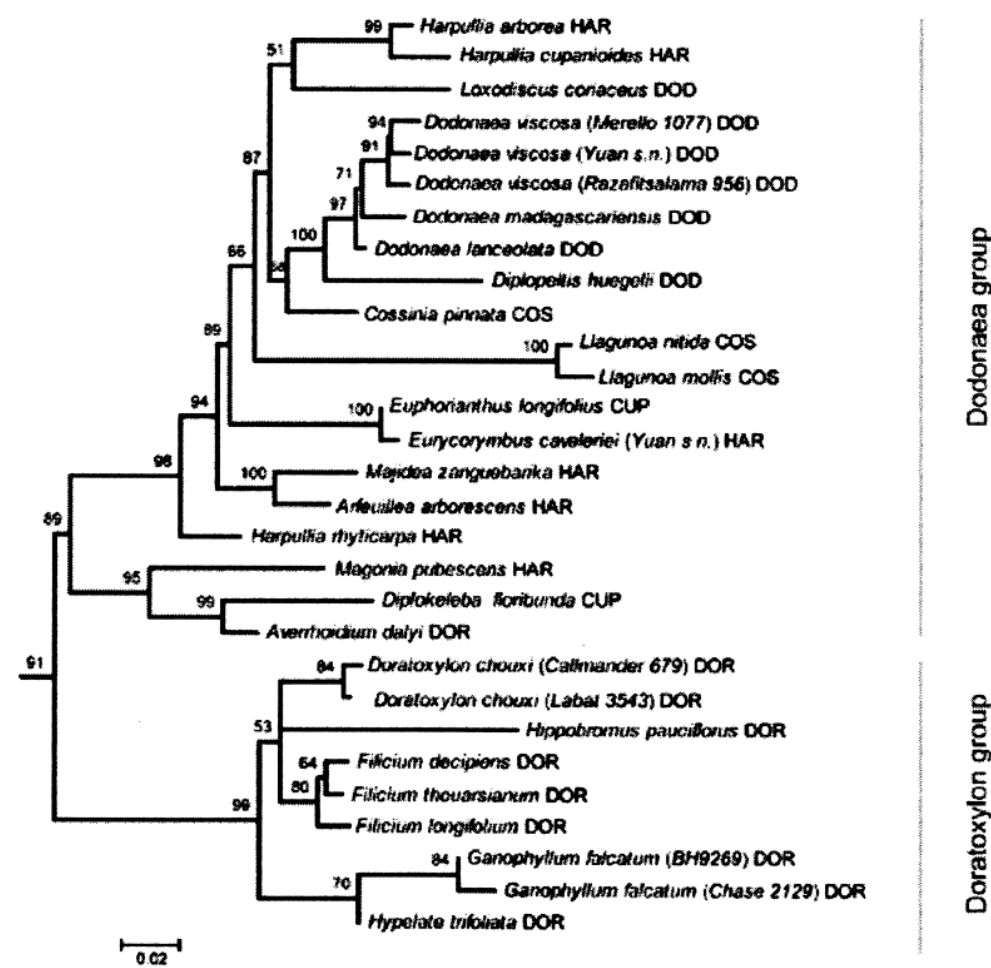

Figura 1- A, filogenia baseada em Máxima Verossimilhança para Sapindaceae s.lat.; B, relações filogenéticas entre e dentro de Aceraceae e Hippocastanaceae; C, relações na subfamília Dodoneoideae, porcentagens de bootstrap indicadas acima dos ramos. COS=Cossinieae; DOD=Dodonaeeae; DOR=Doratoxyleae; HAR=Harpullieae. Definições dos grupos de acordo com Buerki et al. (2009). (Retirado de Buerki et al., 2010) 


\section{Projeto Flora da Serra do Cipó e ocorrência do grupo estudado}

No início da década de 1970, o pesquisador do Instituto de Biociências da USP, Aylthon Brandão Joly, planejou e iniciou o projeto de levantamento da flora da Serra do Cipó, contando com a colaboração da pesquisadora Nanuza Luiza de Menezes (Giulietti et al., 1987). No final da década de 1970 , iniciaram-se os primeiros entendimentos entre pesquisadores da Universidade de São Paulo (USP) e do Royal Botanic Gardens, Kew, Inglaterra, para um estudo sistemático da composição florística da área. Após uma expedição conjunta em 1984, foi formalizado um convênio em 1987, oficializando as relações entre as duas instituições no estudo da vegetação da Cadeia do Espinhaço, (informações em Zappi et al., 2003). Giulietti et al. (1987), publicaram uma lista preliminar da flora vascular da região, trabalho esse que constitui a base para o desenvolvimento de todos os estudos florísticos já realizados.

Outras instituições, notadamente a Universidade Estadual de Feira de Santana, Universidade de Campinas (Unicamp) e Instituto de Botânica de São Paulo (IBt) têm contribuído para um melhor conhecimento da flora da Cadeia do Espinhaço. Atualmente o projeto é coordenado pelo prof. Dr. José Rubens Pirani e conta com a colaboração de pesquisadores, de pósgraduandos e de várias instituições nacionais e internacionais. Dos estudos florísticos, cerca de 87 grupos taxonômicos já foram publicados até o presente.

Em relação à família Sapindaceae na Serra do Cipó, apenas estudos de composição florística pontuais como os de Campos (1995), Meguro et al. (2007), Freitas et al. (2009), Santos (2009) e Valente (2009), foram realizados. Giulietti et al. (1987), em um levantamento preliminar da flora da região apontaram 13 espécies de Sapindaceae distribuídas em 6 gêneros na Serra do Cipó. 


\section{Objetivos}

$\checkmark \quad$ Identificar, descrever e contribuir para o conhecimento da família Sapindaceae no Brasil, por meio da elaboração da monografia da flora da Serra do Cipó, uma vez que várias das espécies estudadas apresentam ampla distribuição geográfica no país;

$\checkmark \quad$ Determinar os caracteres essenciais para a circunscrição das espécies nos gêneros, fazer chaves de identificação, ilustrações e comentários, de acordo com o modelo na Flora da Serra do Cipó;

$\checkmark \quad$ Ampliar e enriquecer as coleções de Sapindaceae dos acervos dos herbários de São Paulo, notadamente SPF e SPFR através das novas coletas e permutas ou doações específicas dessa família,

$\checkmark \quad$ Analisar os materiais de Sapindaceae dos principais herbários com coleções de plantas da Serra do Cipó. 


\section{Material e Métodos}

A estrutura e publicação do trabalho seguiu aquela usual para os trabalhos taxonômicos realizados na Serra do Cipó, delineados por Giulietti et al. (1987) e seguida pelo Boletim de Botânica da Universidade de São Paulo, revista que publica os tratamentos taxonômicos realizados na Serra do Cipó.

\section{1.Área de Estudo}

Também conhecida como Serra Geral, a Serra do Espinhaço, representa a faixa orogênica precambriana mais extensa e contínua do território brasileiro (Almeida-Abreu \& Renger, 2002), constitui um conjunto de serras que se estende ao longo de $1.200 \mathrm{~km}$, na direção sul-norte entre os paralelos $10^{\circ} 30^{\prime}$ a $20^{\circ} 30$ 'S, desde o Quadrilátero Ferrífero, no centro de Minas Gerais, até a Chapada Diamantina, na Bahia, Caxiti et al. (2008). AlmeidaAbreu \& Renger (2002) ampliam este limite até as fronteiras dos estados de PE e PI. Em escala regional, a Serra do Espinhaço é subdividível em dois compartimentos de planaltos, ocupando as partes sul e norte desta, muito bem diferenciados e nitidamente separados por uma zona deprimida NW-SE, denominados Planalto Meridional e Planalto Setentrional (Saadi, 1995), (fig. 2).

A porção meridional, na qual se localiza a Serra do Cipó, estende-se por 300 km na direção N-S, desde o Quadrilátero Ferrífero até a região de Olhos D'Água (Almeida-Abreu, 1995), inicia-se na extremidade meridional da serra, ou seja, nas nascentes do rio Cipó, alojadas na serra homônima, a aproximadamente $50 \mathrm{~km}$ a norte de Belo Horizonte (Saadi, 1995). 


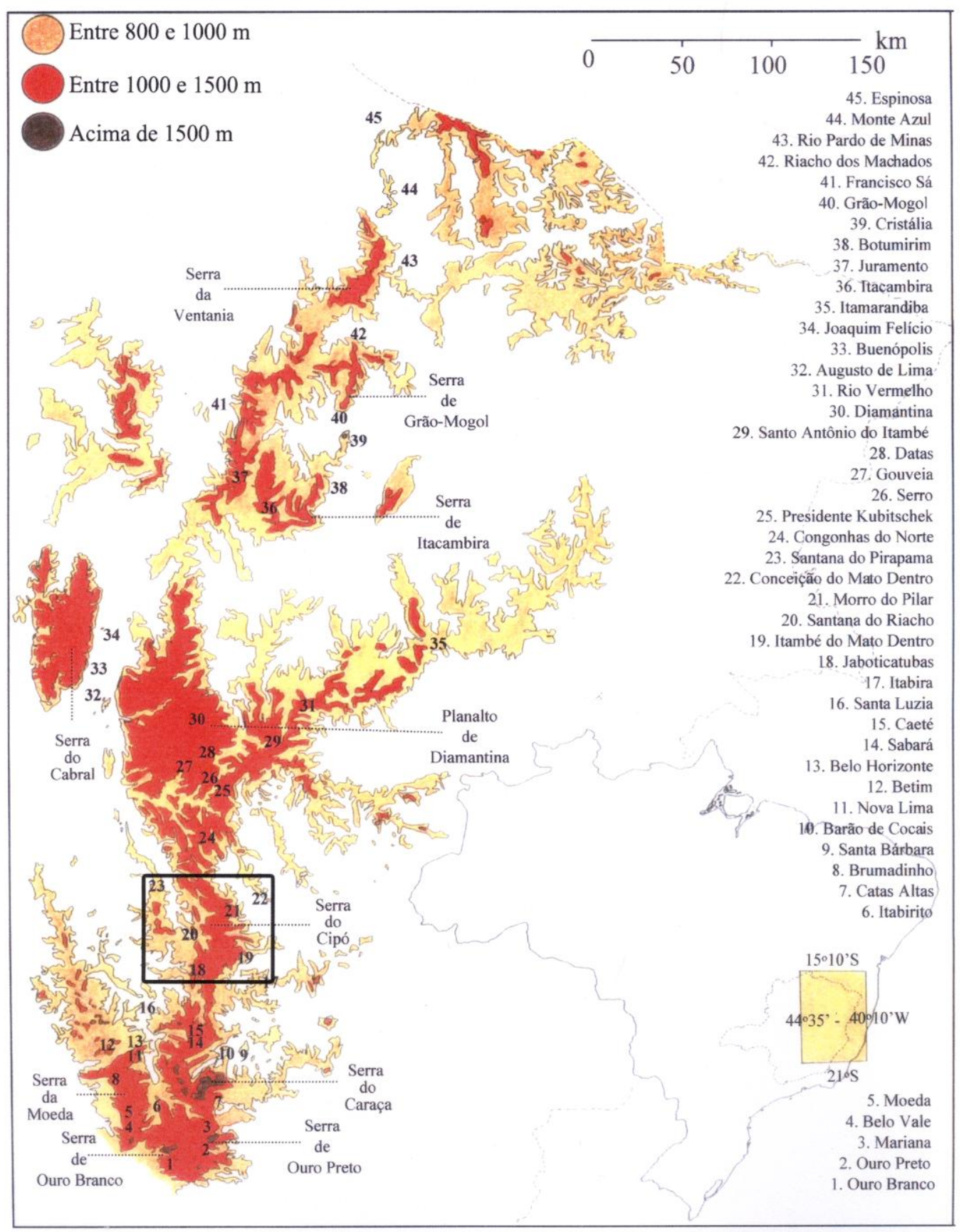

Figura 2- Localização da Cadeia do Espinhaço, com os topônimos principais e destaque para a Serra do Cipó, Minas Gerais. (Retirado de Martins, 2009) 
A Serra do Cipó está cerca de 100 km a nordeste de Belo Horizonte,

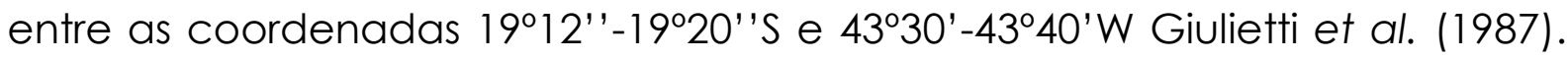
Segundo as Cartas do Brasil em 1:100.000, Folha SE-23-Z-AVI (editado pelo IBGE, 1976), a Serra do Cipó é delimitada pelo Rio Cipó e seus afluentes do leste, especialmente o Rio Paraúna, compreendendo as áreas montanhosas situadas entre a Serra das Bandeirinhas, em Santana do Riacho, ao Sul, e as serras próximas de Gouveia, ao Norte. A região abranje toda a região do Parque Nacional da Serra do Cipó (31.733 ha) (Peloso \& Shimabukuro, 2010) que é inteiramente circundado pela Área de Proteção Ambiental Morro da Pedreira (100107 ha)(Gontijo, 1993), e abrange os municípios de Itambé do Mato Dentro, Jaboticatubas, Morro do Pilar, Santana do Riacho, Itabira, Nova União, Taquaruçu de Minas e Conceição do Mato Dentro (Madeira et al., 2008), (fig. 3).

É edificada essencialmente por litologias do Supergrupo Espinhaço (principalmente rochas quartzíticas e, subordinadamente, rochas filíticas, conglomeráticas e vulcânicas de caráter básico e ácido (Almeida-Abreu, 1995).

A altitude média situa-se em torno de $1.200 \mathrm{~m}$, com ponto culminante em 2062, no Pico do Itambé (Saadi, 1995). Na região da Serra do Cipó, os cumes mais altos são o dos Montes Claros a 1.670 m, na divisa entre Jaboticatubas e Nova União, no extremo sul do Parque Nacional, e os da Serra do Breu, o mais alto, com 1.687 m, inseridos na APA, a oeste do Parque Nacional, no município de Santana do Riacho (Ribeiro, 2009b).

A região representa um dos mais importantes divisores hidrográficos em Minas Gerais. É ocupada em sua maior extensão pela bacia do Rio São Francisco (médio curso), que possui como cursos d'água principais o Rio Cipó e o Rio das Velhas, que escoam de sul para norte, e pelos rios que drenam a bacia do Rio Doce a leste, entre os quais destaca-se como principal curso d'água o Rio Santo Antônio (Schaefer et al., 2008).

O clima na região, segundo a classificação de Köppen (1931), é do tipo Cwb, mesotérmico de verões brandos e estação chuvosa no verão, neste tipo de clima, a temperatura média anual varia de $17,4-19,8^{\circ} \mathrm{C}$, sendo 
a temperatura média do mês mais quente inferior a $22^{\circ} \mathrm{C}$, (Galvão \& Nimer, 1965). Ribeiro (2009) destaca que tal como todos os ambientes montanhosos, - conjunto orográfico da Serra do Cipó impõe drásticas diferenças climáticas ao longo do espaço, de modo que regiões muito próximas podem ter climas bastante distintos, que se refletem na vegetação (transição cerrado/ Mata Atlântica) e em diversos outros componentes ambientais, como solos, hidrologia e padrões erosivos.

A precipitação média anual situa-se entre 1.300 e 1.600 mm, ao longo de toda a região, com concentração nos meses de novembro a março (Ribeiro, 2009b), com um período seco de 3 a 4 meses, coincidindo com o inverno, e um período úmido de 7 a 8 meses, (Galvão \& Nimer, 1965).

Os solos são normalmente rasos, arenosos e afloram por toda à parte as rochas, que são normalmente quartzitos e arenitos (Joly, 1970), pobres em nutrientes e com baixa capacidade de retenção de água. Na Serra do Cipó verifica-se profunda variação nos tipos de solo em função da litologia extremamente variada, das diferenças climáticas e de padrões de deposição e erosão distintos conforme o relevo.

A oeste predominam as diversas fitofisionomias do cerrado, nesta região com ampla ocorrência de ambientes cársticos, relacionados à formação Bambuí, que favorece a formação de latossolos profundos, que por sua vez sustetam cerradões e matas mesófilas, bem como as matas secas sobre os afloramentos rochosos. A leste encontram-se fitofisionomias da Mata Atlântica, seja na forma de uma transição para os campos rupestres, sobre solos quartzosos, sejam formações arbóreas mais fechadas, nos solos profundos derivados do embasamento cristalino (Madeira et al., 2008). Ao norte há um hiato e depois a elevação da Chapada Diamantina, que constitui uma ilha de umidade em meio à caatinga, além de apresentar um conjunto de condições geológicas, climáticas e bióticas bastante peculiares, que levam à ocorrência dos campos rupestres com maior diversidade do país (Madeira, 2009). 


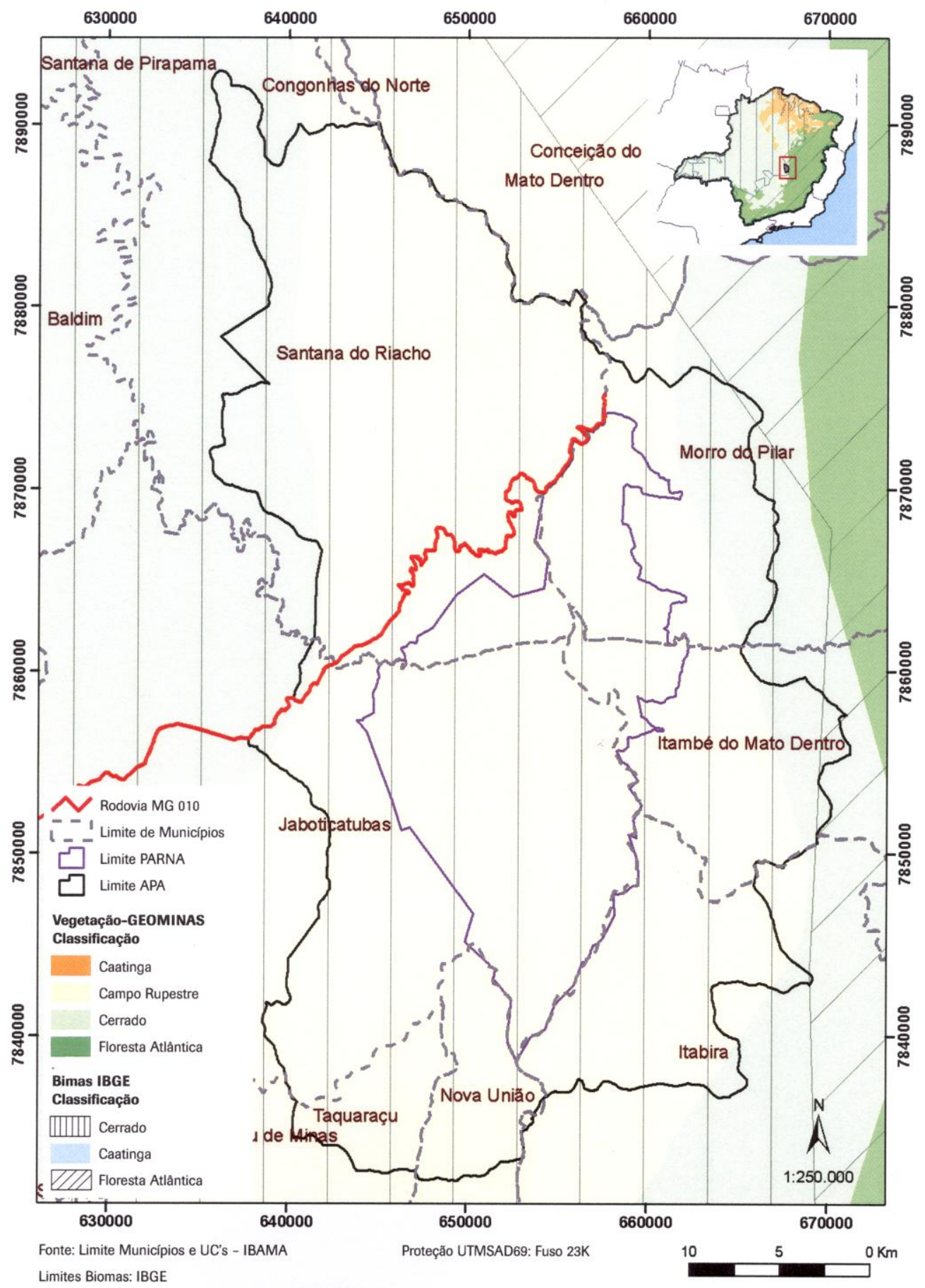

Figura 3- Localização da região da Serra do Cipó, com limites dos municípios e das duas unidades de conservação federais: Parque Nacional da Serra do Cipó e APA Morro da Pedreira. Representa-se ainda o limite oficial atual entre os biomas Mata Atlântica e Cerrado na região conforme o IBGE (zonas hachuradas) e limites vegetacionais conforme GEOMINAS (em cores). No mapa menor, no canto superior esquerdo, apresentam-se as duas unidades de conservação em relação aos biomas Cerrado (verde-claro), Mata Atlântica (verde-escuro) e Caatinga (laranja), no estado de Minas Gerais. (Retirado de Ribeiro et al., 2009). 
No planejamento apresentado por Giulietti et al. (1987), as coletas para os estudos florísticos do Projeto Flora da Serra do Cipó, foi escolhido um trecho mais ao sul, no Município de Santana do Riacho (19¹2-19²0's e $43^{\circ} 30$ $43^{\circ} 40^{\prime}$ W), distando cerca de 100 km de Belo Horizonte, em direção nordeste, onde a estrada entre Belo Horizonte e Conceição do Mato Dentro (MG-010) atravessa essa Serra. No presente trabalho houve uma ampliação da área de coleta sendo incluídos os municípios de Santana de Pirapama e Itambé do Mato Dentro.

\subsection{Levantamento Bibliográfico}

Constou principalmente de ampla consulta as obras específicas e clássicas de Radlkofer (1892-1900, 1933-1934) sobre a família Sapindaceae, além de consulta a sites especializados como 0 W3Tropicos (www.tropicos.org), o Angiosperm Phylogeny Website (Stevens, 2008) e o International Plant Name Index (www.ipni.org) e por referências indiretas.

\subsection{Expedições de coleta}

Foram realizadas sete expedições de coleta e observação de campo na Serra do Cipó:

21-25/IX/2007: 1-Estrada da Usina Pacífico Mascarenhas, 2-estrada sentido cachoeira da caverna, 3-Parque Nacional da Serra do Cipó: trilha para a cachoeira da Farofa, 4-APA Morro da Pedreira e 5-ao longo da rodovia MG 0-10, trecho Santana do Riacho - Conceição do Mato Dentro;

27/VIII-2/IX/2008: 1-ao longo da rodovia MG 0-10, trecho Santana do Riacho - Conceição do Mato Dentro, 2-Parque Nacional da Serra do Cipó: trilha para a cachoeira da Farofa, trilha do Capão dos Palmitos, canyon 
Bandeirinhas, 3-Lapinha João Congo, 4-APA Morro da Pedreira: estrada de terra Santana do Riacho e 5-trilha dos escravos;

4-7/III/2009: 1-Santana de Pirapama: São João de Almeida, 2-trilha da Senhorinha;

14-17/VIII/2009: 1-Estrada de terra MG-232 sentido Morro do Pilar, 2-ao longo da rodovia MG-010, trecho Santana do Riacho-Conceição do Mato Dentro após bifurcação para Morro do Pilar;

17-21/II/2010: 1-Parque Nacional da Serra do Cipó: vale do Ribeirão Bocaína, 2-estrada de terra sentido Santana do Riacho, 3-ao longo da rodovia MG-010, trecho Santana do Riacho-Conceição do Mato Dentro;

27/V- 2/VI/2010: 1-Itambé do Mato Dentro, Santana do Rio Preto (Cabeça de Boi), 2-APA Morro da Pedreira, 3-ao longo da rodovia MG-010, trecho Santana do Riacho-Conceição do Mato Dentro.

Os procedimentos utilizados nos materiais coletados nas viagens a campo foram os usuais para os estudos de taxonomia de Fanerógamas, seguindo Mori et al. (1985). Os materiais foram herborizados conforme técnicas convencionais, depositados nos herbários CTES, SPF e SPFR e distribuídos a outras instituições quando possível.

\subsection{Consulta aos herbários}

Os estudos foram desenvolvidos nas dependências do Laboratório de Sistemática de Plantas, do Departamento de Biologia da Faculdade de Filosofia, Ciências e Letras de Ribeirão Preto (FFCLRP-USP).

Todas as exsicatas de Sapindaceae da Coleção Flora da Serra do Cipó (com coletas iniciadas em 1972) depositadas principalmente no Instituto de Botânica (Herbário SP), no Departamento de Botânica da Universidade de São Paulo (Herbário SPF) e no Herbário da Universidade Estadual de Campinas (Herbário UEC) foram analisadas. 
Os herbários (listados abaixo) foram consultados através de visitas, com solicitação de empréstimo ou de doação dos materiais. Além dos herbários brasileiros, foi consultado o herbário CTES, no qual se teve acesso a alguns materiais tipos de Sapindaceae do acervo e às cópias da coleção fotográfica de materiais-tipo do Field Museum of Natural History (Herbário F, Chicago-EUA), que em muito auxiliaram o trabalho de identificação dos táxons. Também foram examinadas fotos de materiais-tipo ou de referência depositados no herbário US e enviadas pelo Dr. Acevedo-Rodríguez (Smithsonian Institution, Washington, EUA).

Os herbários cujas coleções foram consultadas estão listados a seguir (siglas de acordo com Thiers, 2011);

BHCB-Universidade Federal de Minas Gerais. Brasil. Minas Gerais. Belo Horizonte.

CTES-Instituto de Botánica del Nordeste. Argentina. Corrientes. Corrientes.

ESA-Universidade de São Paulo. Brasil. São Paulo. Piracicaba.

R-Universidade Federal do Rio de Janeiro. Brasil. Rio de Janeiro. Rio de Janeiro.

SP-Instituto de Botânica. Brasil. São Paulo. São Paulo.

SPF-Universidade de São Paulo. Brasil. São Paulo. São Paulo.

SPFR-Universidade de São Paulo. Brasil. São Paulo. Ribeirão Preto.

UEC-Universidade Estadual de Campinas. Brasil. São Paulo. Campinas.

Além dos herbários supracitados, através da internet, foram realizadas consultas a alguns sites de herbários do exterior (US, K, F, MO e NY) para a busca de imagens de tipos e dos materiais depositados. 


\subsection{Análise dos materiais}

Foram examinadas 303 exsicatas provenientes da Serra do Cipó, além de outras utilizadas como material adicional, coletadas em outras localidades.

A terminologia morfológica seguiu Font-Quer (1970) e Radford et al. (1974), Tamaio \& Angyalossy para a adequação terminológica do cilindro vascular composto, típico de algumas trepadeiras, Hickey (1973) para a venação dos folíolos, Briggs \& Johnson (1979) e Weberling (1989) para definir a tipologia das inflorescências, Spujt (1994) para definir o tipo de fruto.

Trabalhos apresentando algumas peculiaridades como os de Weckerle \& Rutishauser (2005) a respeito do gineceu, fruto e estrutura da semente em Paullinieae; Carlquist (1988, 1991), Metcalfe (1983) sobre o crescimento anômalo do caule em algumas espécies de Serjania; Weberling (1976), para as estípulas restritas aos gêneros da tribo Paullinieae, representados aqui pelos gêneros Cardiospermum, Paullinia e Serjania e ausentes na maioria dos outros gêneros ou como pseudoestípulas em algumas espécies de gêneros paleotropicais, também foram consultados.

As abreviações dos nomes dos autores dos táxons estão de acordo Brummitt \& Powell (1992).

As descrições das espécies foram baseadas nos materiais examinados e segue principalmente a literatura especializada da família Sapindaceae, tomando como ponto de partida as obras de Radlkofer (1892-1900, 19331934) e os trabalhos e publicações de Ferrucci (1991, 1995, 2000, 2006), Acevedo-Rodríguez (1990, 1991, 1993), Somner (2001), Somner \& Ferrucci (2004), Somner et al. (2009), Coelho (2008), Gentry \& Steyermark (1987), Reitz (1980), Barkley (1957), Joly (1980), West (1984) e Guarim Neto (1993). Estão acompanhadas de dados sobre nomes populares, observações sobre habitat, fenologia, distribuição geográfica e comentários sobre variabilidade morfológica e taxonomia, obtidas de observações em campo, de dados 
obtidos a partir das etiquetas de herbário, bem como através de bibliografia especializada, além de ilustrações de caracteres diagnósticos utilizados principalmente nas chaves de identificação das espécies.

A análise morfológica detalhada dos materiais herborizados foi realizada por meio do uso de estereomicroscópio ZEISS- Stemi 2000-C. As medidas foram tiradas com régua e paquímetro. Os extremos do tamanho das estruturas quando consideradas pouco comuns foram indicados entre parêntesis. Estruturas que não foram observadas nos materiais examinados (materiais incompletos) tiveram sua descrição complementada com dados da bibliografia, citada logo em seguida da estrutura. As ilustrações foram feitas a mão livre, com auxílio de estereomicroscópio com câmara-clara acoplada.

Nas chaves de identificação dos gêneros e espécies de Sapindaceae foi dada especial atenção a utilização de caracteres vegetativos e de frutos, já que as espécies de Sapindaceae em fruto normalmente podem ser identificadas com relativa segurança.

$\mathrm{Na}$ citação do material examinado foram referidos todos os materiais coletados, pertencentes à área. Tipos nomenclaturais e materiais de referência pertencentes a outras áreas, utilizados para complementar a descrição de materiais, foram citados no material adicional examinado. 


\section{Referências}

ACEVEDO-RODRÍGUEZ, P. 1990. Distributional patterns in Brazilian Serjania (Sapindaceae). Acta bot. bras. 4(1): 69-82.

ACEVEDO-RODRIGUEZ, P. 1991. Serjania lancistipula (Sapindaceae), a new species from Bahia, Brazil. Brittonia 43(3): 165-167.

ACEVEDO-RODRIGUEZ, P. 1993. Systematics of Serjania (Sapindaceae), part I: a revision of Serjania sect. Platycoccus. Memoirs of the New York Botanical Garden 67: 93p.

ACEVEDO-RODRIGUEZ, P., Van Welzen, P.C., Adema, F. \& Van der Ham, R.W.J.M. 2011. Sapindaceae. In: The families and Genera of Vascular Plants - Flowering Plants Eudicots: Sapindales, Cucurbitales, Myrtaceae (K. Kubitzki, Ed.). Springer-Verlag Berlin Heidelberg. 201 1, v. 10, 356-406p.

ALMEIDA-ABREU, P.A. 1995. O Supergrupo Espinhaço da Serra de Espinhaço Meridional (Minas Gerais): o rifte, a bacia e o orógeno. Geonomos 3:118.

ALMEIDA-ABREU, P.A. \& Renger, F.E. 2002. Serra do Espinhaço meridional: um orógeno de colisão do mesoproterozoico. Revista Bras. Geoc. 32(1): 114.

APG (ANGIOSPERM PHYLOGENY GROUP) II. 2003. An update of the Angiosperm Phylogeny Group classification for the orders and families of flowering plants: APG II. Bot. J. Linnean Soc. 141: 399-436.

APG (ANGIOSPERM PHYLOGENY GROUP) III. 2009. An update of the Angiosperm Phylogeny Group classification for the orders and families of flowering plants: APG III. Bot. J. Linnean Soc. 161: 105-121.

BARKLEY, F.A. 1957. Sapindaceae of Southern South America. Lilloa. 28: 111 179.

BENTHAM, G. \& Hooker, J.D. 1862. Genera Plantarum, v. 1. London. 463p.

BORGES, L.M. 2010. Mimosoideae na Serra do Cipó, Minas Gerais e análise da variabilidade morfológica de Mimosa macedoana Burkart. Dissertação (Mestrado) - Instituto de Biociências da Universidade de São Paulo. Departamento de Botânica. 104p. 
BRIGGS, B.G. \& Johnson, L.A.S. 1979. Evolution in the Myrtaceae - evidence from inflorescence structure. Proc. Linn. Soc. N.S.W. 102: 157-256.

BRUMMIT, R.K. \& Powell, C.E. 1992. Authors of plant names. London: Royal Botanic Gardens, Kew. 732p.

BUERKI, S.; Forest, F.; Acevedo-Rodríguez, P.; Callmander, M.W.; Nylander, J.A.A.; Harrington, M.; Sanmartín, I.; Küpfer, P. \& Alvarez, N. 2009. Plastid and nuclear markers reveal intricate relationships at subfamilial and tribal levels in the soapberry family (Sapindaceae). Mol. Phylogenetics and Evol. $51(2): 238-258$.

BUERKI, S.; Lowry II, P.P.; Alvarez, N.; Razafimandimbison, S.G.; Küpfer, P. \& Callmander, M.W. 2010. Phylogeny and circumscription of Sapindaceae revisited: molecular sequence data, morphology and biogeography support recognition of a new family, Xanthoceraceae. Plant Ecology and Evolution, 1-12.

CAMPOS, M.T.V.A. 1995. Composição florística e aspectos da estrutura e da dinâmica de três capões na Serra do Cipó, Minas Gerais, Brasil. Dissertação (Mestrado) - Universidade de São Paulo. Instituto de Biociências. 145p.

CANDOLE, A.P. de 1824. Sapindaceae. In: Prodromus Systematis Naturalis Regni Vegetabilis 1. Paris: Treuttel \& Würtz, 601-618p.

CARLQUIST, S. 1991. Anatomy of vine and liana stems: a review and synthesis. In: The Biology of vines (F.E. Putz \& H.A. Mooney, Eds.). New York: Cambridge University Press. 53-71p.

CARLQUIST, S. 1998. Comparative wood anatomy: systematic, ecological and evolutionary aspects of dicotyledon wood. Springer-Verlag, Berlin Heidelberg New York.

CAXITI, F.A.; Santos, Y.L.O.P.; Uhlein, A.; Pedreira, A.J. \& Faulstich, F.L. 2008. A geologia entre Macaúbas e Canatiba (Bahia) e a evolução do supergrupo espinhaço no Brasil Oriental. Geonomos 16(1): 11-20.

CHASE, M.W.; Soltis, D.E.; Olmstead, R.G.; Morgan, D.; Les, D.H.; Mishler, B.D.; Duvall, M.R.; Price, R.A.; Hills, H.G.; Qiu, Y-L.; Kron, K.A.; Retting, J.H.; Conti, E.; Palmer, J.D.; Manhart, J.R.; Sytsma, K.J.; Michaels, H.J.; Kress, W.J.; Karol, K.G.; Clark, W.D.; Hedrén, M.; Gaut, B.S.; Jansen, R.K.; Kim, K-J.; Wimpee, C.F.; Smith, J.F.; Furnier, G.R.; Strauss, S.H.; Xiang, Q-Y.; Plunkett, G.M.; Soltis, P.S.; Swensen, S.M.; Willians, S.E.; Gadek, P.A.; Quinn, C.J.; Eguiarte, L.E.; Goldenberg, E.; Learn Jr., G.H.; Graham, S.W.; Barrett, S.C.H.; Dayanandan, S. \& Albert, V.A. 1993. Phylogenetics of seed plants: 
an analysis of nucleotide sequences from the plastid gene rbcL. Annais Missouri Botanical Garden 80: 528-580.

COELHO, R.L.G. 2008. Estudos taxonômicos em Matayba Aubl. Sect. Matayba (Sapindaceae). Dissertação (Mestrado) - Universidade Estadual de Campinas. Instituto de Biologia. 170p.

CRONQUIST, A. 1988. The evolution and classification of flowering plants, ed.2. New York Botanical Garden Press. 555p.

DAHLGREN, G. 1989. An update system of classification. Bot. J. Linnean Soc. 100: 197-203.

FERRUCCI, M.S. 1991. Sapindaceae. In: Spichiger \& Ramella (Eds.), Flora del Paraguay. Conservatoire et Jardin Botaniques de la Ville de Genéve \& Luis, Missouri Botanical Garden, 16: 1-144p.

FERRUCCI, M.S. 1995. Sapindaceae. In: Stannard, B.L., Flora of the Pico das Almas: Chapada Diamantina - Bahia, Brazil. Royal Botanic Gardens, Kew - 853p.

FERRUCCI, M.S. 2000. Revisión taxonómmica de los géneros Cardiospermum y Urvillea para el Neotrópico (Sapindaceae). Ph.D. dissertation, Universidad Nacional de Cordoba. Argentina, 262p.

FERRUCCI, M.S. 2006. Flora de Grão-Mogol, Minas Gerais: Sapindaceae. Bol. Bot. Univ. São Paulo 24: 79-86.

FONT QUER, P. 1970. Diccionario de Botánica. Barcelona: Labor, 4ª ed., 1244p.

FREITAS, M. de F.; Carrijo, T.T.; Leão, L.C.S. \& Kinoshita, L.S. 2009. Flora da Serra do Cipó, Minas Gerais: Myrsinaceae. Bol. Bot. Univ. São Paulo, 27(2): 259267.

GADEK, P.A. ; Fernando, E.S. ; Quinn, C.J. ; Hoot, S.B. ; Terrazas, T. ; Sheahan, M.C. \& Chase, M.W. 1996. Sapindales: molecular delimitation and infraordinal groups. American Journal of Botany, 83(6): 802-811.

GALVÃO, M.V. \& Nimer, E. 1965. Clima. In IBGE (ed.) Geografia do Brasil Grande Região Leste. Rio de Janeiro, v. 5, 91-139.

GENTRY, A.H. \& Steyermark, J. 1987. A revision of Dilodendron (Sapindaceae). Annals of the Missouri Botanical Garden, 74(3): 533-538.

GIULIETTI, A.M.; Menezes, N.L.; Pirani, J.R.; Meguro, M. \& Wanderley, M.G.L. 1987. Flora da Serra do Cipó, Minas Gerais: caracterização e lista das espécies. Bol. Bot. Univ. São Paulo, 9: 1-151. 
GONTIJO, A.H.F. 1993. O relevo da Serra do Cipó, Minas Gerais - Espinhaço Meridional. Dissertação (Mestrado) - Universidade de São Paulo.

GUARIM NETO, G. 1985. Estudos taxonômicos em Cupania L. (Sapindaceae): as espécies brasileiras. Tese (Doutorado) apresentada ao INPA/FUA. Manaus (AM). 272p.

GUARIM NETO, G. 1993. Novas espécies de Cupania L. (Sapindaceae) para o Brasil. Eugeniana, 20: 7-15.

GUARIM NETO, G.; Santana, S.R. \& Silva, J.V.B. da, 2000. Notas etnobotânicas de espécies de Sapindaceae Jussieu. Acta bot. bras. 14(3): 327-334.

HARRINGTON, M.G.; Edwards, K.J.; Johnson, S.A.; Chase, M.W. \& Gadek, P.A. 2005. Phylogenetic inference in Sapindaceae sensu lato using plastid matK and rbcL DNA sequences. Syst. Bot. 30(2): 366-382.

HICKEY, L.J. 1973. Classification of the Architecture of Dicotyledonous Leaves. American Journal of Botany 60(1): 17-33.

JOLY, A.B. 1970. Conheça a vegetação brasileira. Edusp \& Polígono. São Paulo. 165p.

JOLY, C.A.; Felippe, G.M. \& Melhem, T.S. 1980. Taxonomic studies in Magonia St.-Hill (Sapindaceae). Brittonia 32(3): 380-386.

JUDD, W.S.; Campbell, C.S.; Kellog, E.A. \& Stevens, P.F. 2002. Plant Systematic: a phylogenetic approach. ed. 2. Sinaver Associates, Inc: USA, 341-347p.

JUDD, W.S.; Campbell, C.S.; Lellogg, E.A.; Stevens, P.F. \& Donogue, M.J. 2008. Plant Systematics: a phylogenetic approach. ed. 3. Sinaver Associates, Inc: USA, 429-440p.

JUDD, W.S.; Campbell, C.S.; Kellog, E.A.; Stevens, P.F. \& Donoghue, M.J. 2009. Sistemática Vegetal: um enfoque filogenético. ed. 3. Porto Alegre: Artmed, 429-440p.

JUSSIEU, A.L. 1789. Genera plantarum. Herissant \& Barrois, Paris. 594p

KAMINO, L.H.Y.; Oliveira-Filho, A.T. \& Stehmann, J.R. 2008. Relações florísticas entre as fitofisionomias florestais da Cadeia do Espinhaço, Brasil. Megadiversidade 4(1-2): 38-77.

KEW Royal Botanic Gardens. Disponível em http://www.kew.org/collections/herbcol.html. Acessado em janeiro 2011. 
KÖPPEN, W. 1931. Climatologia. Fondo de Cultura Econômica. Buenos Aires.

KUBITZKI, K. 2011 . The families and Genera of Vascular Plants - Flowering Plants Eudicots: Sapindales, Cucurbitales, Myrtaceae. Springer-Verlag Berlin Heidelberg. 2011, v. 10, 1-6p.

MADEIRA, J.A.; Ribeiro, K.T.; Oliveira, M.J.R.; Nascimento, J.S. \& Paiva, C.L. 2008. Distribuição espacial do esforço de pesquisa biológica na Serra do Cipó, Minas Gerais: subsídios ao manejo das unidades de conservação da região. Megadiversidade 4 (1-2): 255-269.

MADEIRA, J.A. 2009. Plano de manejo do Parque Nacional da Serra do Cipó e Área de Proteção Ambiental Morro da Pedreira. Encarte 2. 102p. Disponível em www.ufmg.br/pos/ecologia/usfish/index.php/plano-demanejo/downloads

MARTINS, E.G.A. 2009. O Clado Urticoide (Rosales) na Flora da Serra do Cipó, Minas Gerais. Dissertação (Mestrado)-Instituto de Biociências da Universidade de São Paulo. Departamento de Botânica. 145p.

MEGURO, M.; Pirani, J.R.; Mello-Silva, R. \& Cordeiro, I. 2007. Composição florísica e estrutura das florestas estacionais decíduas sobre calcário a oeste da Cadeia do Espinhaço, Minas Gerais, Brasil. Bol. Bot. Univ. São Paulo 25(2): 147-171.

METCALFE, C.R. 1983. Anomalous structure. In: C.R. Metcalfe \& L. Chalk. Anatomy of the dicotyledons. $2^{\text {nd }}$ Ed Oxford, Claredon Press.

MORI, S.A.; SILVA, L.A.M.; Lisboa, G. \& Coradin, L. 1985. Manual de manejo do herbário fanerogâmico. Centro de Pesquisas do Cacau-llhéus-Bahia. $98 p$.

MULLER, J. \& Leenhouts, P.W. 1976. A general survey of pollen types in Sapindaceae in relation to taxonomy. In: Ferguson, J.K., Muller, J. (eds.) The evolutionary significance of the exine. Linnean Soc. Symp. Ser. 1, London: Academic Press. 407-445p.

PELOSO, B.D.A. \& Shimabukuro, Y.E. 2010. Revista Brasileira de cartografia $62 / 01,103-118$.

RADFORD, A.E.; Dickinson, W.C.; Massey, J.R. \& Bell, C.R. 1974. Vascular plants systematic. Harper \& Row Publischers. New York.

RADLKOFER, L. 1892-1900. Sapindaceae. In: Martius, C.F. - Flora Brasiliensis. 13: 225-679. 
RADLKOFER, L. 1933-1934. Sapindaceae. In: ENGLER, A. (Ed.), Die Naturlichen Pflanzenfamilien 98a-h, (Heft. IV.165): 1539p.

RANDO, J.G. 2009. Chamaecrista seções Apoucoutia, Chamaecrista e Xerocalyx na Serra do Cipó, Minas Gerais, Brasil. Dissertação (Mestrado) - Instituto de Biociências da Universidade de São Paulo. Departamento de Botânica. 107p.

REITZ, R. 1980. Sapindaceae. In: Reitz, R. (org.). Flora llustrada Catarinense. Herbario Barbosa Rodrigues, Itajai. 160p.

RIBEIRO, K.T.; Nascimento, J.S.; Madera, J.A. \& Ribeiro, L.C. 2009. Aferição dos limites da Mata Atlântica na Serra do Cipó, MG, Brasil, visando maior compreensão e proteção de um mosaico vegetacional fortemente ameaçado. Natureza \& Conservação 7(1): 30-48.

RIBEIRO, K.T. in Org.: Madeira, J.A. 2009b. Plano de manejo do Parque Nacional da Serra do Cipó e Área de Proteção Ambiental Morro da Pedreira. Encarte 2. 102p. Disponível em www.ufmg.br/pos/ecologia/usfish/index.php/plano-demanejo/downloads

SAADI, A. 1995. A geomorfologia da Serra do Espinhaço em Minas Gerais e de suas margens. Geonomos 3(1): 41-63.

SANTOS, M.F. 2009. Análise florística em Floresta Estacional Semidecidual na encosta leste da Serra do Cipó, MG. Dissertação (Mestrado) - Instituto de Biociências da Universidade de São Paulo. Departamento de Botânica. 145p.

SAVOLAINEN, V.; Fay, M.F.; Albach, D.C.; Backlund, A.; Van der Bank, M.; Cameron, K.M.; Johnson, S.A.; Lledó, M.D.; Pintaud, J.-C.; Powell, M.; Sheahan, M.C.; Soltis, D.E.; Soltis, P.S.; Weston, P.; Whitten, W.M.; Wurdack, K.J. \& Chase, M.W. 2000. Phylogeny of the eudicots: a nearly complete familial analysis based on $r b c L$ gene sequences. Kew Bulletin 55: 257-309.

SCHAEFER, C.E.R.; Michel, R.F.M.; Chagas, C.S.; Fernandes Filho, E.I.; Valente, E.L.; Souza, E.; Vasconcelos, B.N.F. \& Ribeiro, A.S.S. 2008. Relatório do levantamento pedológico, geomorfológico e geológico para o Plano de manejo do parque Nacional da Serra do Cipó e APA Morro da Pedreira. Viçosa: UFV/DPS.

SMITHSONIAN National Museum of natural History. Disponível em http://botany.si.edu/. Acessado em janeiro 2011. 
SOLTIS, D.E.; Soltis, P.S.; Endress, P.K. \& Chase, M.W. 2005. Phylogeny and Evolution of Angiosperms. Washington: Smithsonian Books. 370p.

SOMMER, G.V. 2001. Paullinia L. (Sapindaceae): Morfologia, Taxonomia e Revisão de Paullinia sect. Phygoptiton. Tese (Doutorado)-Instituto de Biociências da Universidade de São Paulo. Departamento de Botânica. $275 p$.

SOMNER, G.V. \& Ferrucci, M.S. 2004. A new species of Cupania sect. Trigonocarpus (Sapindaceae) from Brazil. Bot. J. Linnean Soc. 146: $217-$ 221.

SOMNER, G.V.; Ferrucci, M.S.; Rosa, M.M.T. \& Coelho, R.G.L. 2009. Sapindaceae. In: Martins, S.E.; Wanderley, M.G.L.; Shepherd, G.J.; Giulietti, A.M. \& Melhem, T.S. (Eds.). Flora Fanerogâmica do estado de São Paulo. Instituto de Botanica, Sao Paulo, v. 6. 195-255p.

SOMNER, G.V.; Ferrucci, M.S.; Acevedo-Rodríguez, P. 2010. Sapindaceae. In: Forzza, R.C. et al. 2010. Lista de Espécies da Flora do Brasil. Jardim Botânico do Rio de Janeiro. Disponível em http://floradobrasil.jbrj.gov.br/

SOUZA, C.Z. \& Lorenzi, H. 2005. Botânica Sistemática - Guia llustrado para identificação das famílias de Angiospermas da flora brasileira, baseado em APG II. Nova Odessa, SP: Instituto Plantarum. 640p.

SPUJT, R.W., 1994. A systematic treatment of fruit types. Memoirs of the New York Botanical Garden 70: 182p.

STEVENS, P.F. Versão 9, junho 2008. Angiosperm Phylogeny Website. Disponivel em http://www.mobot.org/MOBOT/research/APWeb/. Acessado em 01.3.2011.

TAKHTAJAN, A. 1997. Diversity and classification of flowering plants. New York: Columbia University Press.

TAKHTAJAN, A.L. (Ed.) 1981. Flowering Plants, v. 5(2). Moscow: Proswyeschtschenye.

TAMAIO, N. \& Angyalossy, V. 2009. Variação cambial em Serjania caracasana (Sapindaceae): enfoque na adequação terminológica. Rodriguesia 60(3): 651-666.

THE FIELD MUSEUM. Botany Collections Database. Disponível em http://www.fieldmuseum.org. Acessado em janeiro 2011. 
THE NEW YORK BOTANICAL GARDEN. Disponível em http://sciweb.nybg.org/science2/hcol/vasc/index.asp. Acessado em janeiro 2011.

THIERS, B. (janeiro 2011) Index Herbariorum: A global directory of public herbaria and associated staff. New York Botanical Garden's Virtual Herbarium. Disponível em http://sweetgum.nybg.org/ih/

THORNE, R.F. \& Reveal, J.L. 2007. An update classification of the class Magnoliopsida ("Angiospermae). Bot. Rev. 73: 67-182.

TROPICOS.org. Missouri Botanical Garden. Disponível em http://www.tropicos.org. Acessado em janeiro 2011.

VALENTE, E.L. 2009. Relações solo-vegetação no Parque Nacional da Serra do Cipó, Espinhaço Meridional, Minas Gerais. Tese (Doutorado)Universidade Federal de Viçosa. 157p.

WEBerLING, F. 1976. Die Pseudostipeln der Sapindaceae. Akad. Wiss. Lit. Mainz., Abh. Math.-Naturwiss. KI. 2: 5-27.

WEBERLING, F. 1989. Morphology of flowers and inflorescences. Cambridge Univ. Press. Cambridge. 405p.

WECKERLE, C.S.; Rutishaver, R. 2005. Gynoecium, fruit and seed structure of Paullinieae (Sapindaceae). Bot. J. Linn. Soc. 147: 159-189.

WEST, J.G. 1984. A revision of Dodonaea Miller (Sapindaceae) in Australia. Brunonia 7: 1-194.

ZAPPI, D.C.; Lucas, E.; Stannard, B.L.; Lughadha, E.N.; Pirani, J.R.; Queiroz, L.P. de ; Atkins, S.; Hind, D.J.N.; Giulietti, A.M.; Harley, R.M. \& Carvalho, A.M. de 2003. Lista das plantas vasculares de Catolés, Chapada Diamantina, Bahia, Brasil. Bol. Bot. Univ. São Paulo 21 (2): 345-398. 


\title{
FLORA DA SERRA DO CIPÓ, MINAS GERAIS: SAPINDACEAE
}

\begin{abstract}
Flora of Serra do Cipó, Minas Gerais: Sapindaceae). The study of the family Sapindaceae is a part of the Project of "Flora of Serra do Cipó, Minas Gerais, Brazil". The family is represented there by 39 species distributed in 10 genera: Allophylus, Cardiospermum, Cupania, Dilodendron, Dodonaea, Matayba, Magonia, Paullinia, Serjania and Toulicia. Key to genera and species, descriptions and illustrations, as well as comments on the geographic distribution, phenology and morphological variability of the species are presented.
\end{abstract}

Resumo - (Flora da Serra do Cipó, Minas Gerais: Sapindaceae). O estudo da família Sapindaceae é parte do levantamento da "Flora da Serra do Cipó, Minas Gerais, Brasil". A família está representada na área por 39 espécies distribuídas em 10 gêneros: Allophylus, Cardiospermum, Cupania, Dilodendron, Dodonaea, Matayba, Magonia, Paullinia, Serjania e Toulicia. São apresentadas chaves para os gêneros e espécies, descrições e ilustrações das mesmas, além de comentários sobre sua distribuição geográfica, fenologia e variabilidade morfológica.

Key words: Sapindaceae, Serra do Cipó, campo rupestre vegetation, Brazil.

\footnotetext{
1 Trabalho realizado segundo o planejamento apresentado por Giulietti et al. (1987). Manuscrito a ser submetido para publicação no Boletim de Botânica da Universidade de São Paulo.
} 


\section{Sapindaceae}

Árvores, arbustos ou trepadeiras escandentes com gavinhas, geralmente monoicas, látex presente ou ausente, glabras ou com indumento, tricomas simples e glandulares breves; caule simples (1 único cilindro vascular) ou em algumas trepadeiras composto (1 cilindro vascular central e 1-10 periféricos ou 5 dispostos radialmente), lenticelas presentes ou ausentes. Folhas compostas, paripinadas ou imparipinadas, raro simples, alternas ou subopostas, pecíolo e raque marginados, alados ou sem alas, estípulas ausentes ou presentes nas trepadeiras; folíolos inteiros ou serreados a denteados, folíolo distal rudimentar geralmente presente nas árvores e arbustos, domácias presentes ou ausentes. Inflorescências em tirsos simples ou duplos, axilares ou terminais, geralmente pedunculados, brácteas e bractéolas geralmente persistentes. Flores unissexuais, raro perfeitas, 4-5meras, pediceladas, pistiladas com estaminódios e estaminadas com pistilódio, actinomorfas ou zigomorfas, geralmente diclamídeas; cálice dialissépalo, raro gamossépalo; corola presente, raro ausente, dialipétala, apêndice petaloide basal presente, raro ausente, nectário floral extraestaminal, raro intraestaminal ou ausente, localizado na base do androginóforo; androceu com 8 estames, geralmente livres entre si, filetes filiformes, cilíndricos ou achatados, anteras bitecas, geralmente dorsifixas; gineceu sincárpico, ovário súpero, (2)-3-carpelar, (2)-3- locular, placentação axilar, 1-2-(6-8) óvulos por lóculo, estilete filiforme, cilíndrico ou achatado, estigma 2-3-fido, lobos geralmente livres ou concrescidos. Fruto esquizocarpo, mericarpos alados ou cocos drupáceos, cápsula loculicida ou septífraga. Semente geralmente com arilo ou sarcotesta, embrião geralmente curvo, radícula alojada em uma dobra da testa.

Sapindaceae s.s. compreende ca. 1756 espécies e 136 gêneros. Buerki et al. (2010), em seu trabalho mais recente de filogenia utilizando 243 amostras representando 104 dos 142 gêneros reconhecidos de Sapindaceae 
S.I., através de sequência de dados analizadas com os marcadores (ITS e matK, rpoB, trnD-trnT, trnK-matK, trnL-trnF e trnS-trnG), confirmam a consistência de Sapindaceae s.l. adotada por diversos autores (APG II, III, Harrington et al. 2005; Buerki et al. 2009), entretanto apontam a presença de diversos problemas conceituais na circunscrição ampla da família Sapindaceae e concluem ser mais vantajoso manter Aceraceae, Hippocastanaceae e Sapindaceae s.s. (excluindo Xanthoceras) como entidades morfologicamente e biogeograficamente coerentes qual tem sido reconhecidas por mais de um século, e a fim de tornar Sapindaceae s.s. monofilética, propõem colocar Xanthoceras em uma nova monotípica familia, Xanthoceraceae.

Nas Américas ocorrem 38 gêneros, dos quais 33 são exclusivos deste continente (Somner \& Ferrucci 2009). No Brasil está representada por 25 gêneros e ca. 411 espécies (Somner et al. 2010). A família possui uma distribuição predominantemente pantropical com ocorrência de alguns táxons em áreas temperadas (e.g. Atalaya, Diplopeltis, Dodonaeae) (Buerki et al. 2009), as espécies podem ser encontradas em diversos ambientes e tipos vegetacionais (Souza \& Lorenzi 2005, Somner et al. 2010).

O levantamento preliminar da família realizado por Giulietti et al. (1987) indicou a presença de 13 espécies distribuídas em 6 gêneros na Serra do Cipó. Este trabalho aumenta esses números, registrando 39 espécies em 10 gêneros na região.

Bibliografia básica: Acevedo-Rodríguez (1993), Acevedo-Rodríguez et al. (2011), Barkley (1957), Buerki et al. (2009, 2010), Croat (1976), Ferrucci (2000), Gadek et al. (1996), Harrington et al. (2005), Radlkofer (1892, 19311934), Reitz (1980), Somner \& Ferrucci (2009), Somner et al. (2010). 


\section{Chave para os gêneros}

1.Folhas simples. Nectário floral ausente ou intraestaminal 5. Dodonaea 1 '.Folhas compostas. Nectário floral presente e extraestaminal.

2.Trepadeiras sublenhosas ou lenhosas, gavinhas e estípulas presentes.

3.Fruto esquizocarpo com 3 mericarpos, núcleo seminífero no ápice do fruto. 9. Serjania

3'.Fruto cápsula septífraga, núcleo seminífero no meio do fruto.

4.Flor com 4 lobos nectaríferos ovoides. Fruto com pericarpo subcarnoso, vermelho; semente com arilo carnoso.........................................................................8. Paullinia

4'.Flor com 2 lobos nectaríferos corniculiformes. Fruto com pericarpo cartáceo, castanho-amarelado, semente com arilo seco

2. Cardiospermum

2'.Árvores ou arbustos, gavinhas e estípulas ausentes.

5.Folhas bipinadas

4. Dilodendron

5'.Folhas pinadas.

6.Fruto esquizocárpico.

7.Mericarpos drupáceos; folhas imparipinadas, 3foliolada. 1. Allophylus

7'.Mericarpos samaroides, folhas paripinadas, 7-10 pares de folíolos 10. Toulicia 6'.Fruto cápsula loculicida.

8.Flores zigomorfas, pétalas púrpuras na face adaxial, apêndice basal ausente, 6-8 óvulos por lóculo. Sementes complanadas, aladas, arilo ausente. 6. Magonia

8'.Flores actinomorfas, pétalas brancas, apêndice basal presente, 1 óvulo por lóculo. Sementes ovoides ou obovoides, não aladas, arilo presente. 
9.Cálice gamossépalo, com abertura precoce....................................................7. Matayba 9'.Cálice dialissépalo, sem abertura precoce 3. Cupania

\section{Allophylus $\mathrm{L}$.}

Arbustos ou árvores, monoicos, ramos quase cilíndricos ou estriados, jovens pubérulo-pubescentes ou hirsuto-pubescentes, adultos glabrescentes, lenticelas lineares ou verrucosas, castanho-claras. Folhas imparipinadas, 3folioladas, alternas, pecioluladas; folíolos subcartáceos ou cartáceos, denteado-serreados, domácias presentes ou ausentes, venação craspedódroma. Tirso simples ou duplo, subespiciforme, axilar ou terminal, cincinos 2-6-floros, curto pedunculados; brácteas e bractéolas triangularsubuladas. Flores zigomorfas; cálice 4-(5)-mero, dialissépalo, sépalas cuculadas, 2 externas ovadas ou obovadas e 2-3 internas elípticas ou obovadas; corola 4-(5)-mera, pétalas geralmente espatuladas, glandulosas, apêndice petaloide com ápice emarginado formando 2 linguetas inflexas, vilosas, nectário floral unilateral, 4 lobos nectaríferos; flor đ̊̄: estames exertos; flor q: gineceu com ovário 2-carpelar, 1 óvulo por carpelo, estilete filiforme, estigma bífido. Fruto esquizocárpico, 1-2 cocos, mericarpo drupáceo, epicarpo membranáceo, mesocarpo carnoso alaranjado ou avermelhado, endocarpo lenhoso. Sementes ovoides, tegumento membranáceo, arilo ausente.

Gênero cosmopolita com cerca 255 espécies, representado em regiões tropicais e subtropicais (Ferrucci et al. 2009). O Brasil apresenta a maior concentração de espécies, com cerca de 31, sendo 11 endêmicas, e podem ser encontradas em diversos ambientes e tipos vegetacionais (Somner et al. 2010). Na Serra do Cipó ocorrem duas espécies. 


\section{Chave para as espécies de Allophylus}

1.Folíolos elíptico-lanceolados, glabros, com tricomas espalhados sobre a nervura média, domácias ausentes, margem subinteira ou denteadaserreada no $1 / 2$ distal, venação craspedódroma mista. Tirso geralmente duplo na base. 1.1. A. petiolulatus

1 '.Folíolos oval-lanceolados ou oboval-lanceolados, levemente romboidais, face adaxial hirsuta-pubescente e face abaxial pubescente, domácias barbadas, margem serrulada até a base, venação craspedódroma simples. Tirso simples

1.2. A. sericeus

1.1. Allophylus petiolulatus Radlk., Ergänz. Monogr. Serjania 16(1): 181. 1886.

Prancha 1, fig. A.

Árvore ou arbusto 3-9 m alt., ramos pubérulos ou pubescentes, indumento amarelado, ramos jovens vináceos. Folhas brilhantes, pecíolo 1,19,4 cm compr., cilíndrico ou complanado na face adaxial e ápice, peciólulo ca. 5-9 mm compr., maior no folíolo terminal; folíolos 3-15 x 1-4,2 cm, elípticolanceolados, cartáceos, ápice acuminado, geralmente falcado, denteadoserreado no $2 / 3$ distal, base decurrente ou menos freqüentemente oblíqua, face adaxial glabra, face abaxial pilosa na nervura média, tricomas glandulares dispersos em ambas faces, domácias ausentes, venação craspedódroma mista. Tirso simples, duplo na base, axilar ou terminal, com dois ramos na base, ca. $8 \mathrm{~cm}$ compr, pubérulo ou pubescente, cincinos 4-6floros, brácteas e bractéolas 1-2 mm compr., pubescentes. Flores $3 \mathrm{~mm}$ compr., sépalas 4 , ca. 1,5 × 1-2 mm, obovadas, face adaxial glabra, face abaxial pilosa nas nervuras, margem ciliada, tricomas simples e glandulares, pétalas 1,5 mm compr., glandulosas; lobos nectaríferos 4, retangulares; flor 3 : filetes ca. 2,5mm compr., quase cilíndricos, tricomas espalhados e adpressos, anteras glabras, pistilódio viloso; flor o: estaminódios ca. $1 \mathrm{~mm}$ compr., ovário 
arredondado, pubescente, estilete ca. $1 \mathrm{~mm}$ compr. Fruto jovem $8 \times 5 \mathrm{~mm}$, piriforme, epicarpo pubérulo, semente ovoide, 0,7 x 0,4 mm.

Material examinado: Minas Gerais, Itambé do Mato Dentro, Distrito de Santana do Rio Preto (Cabeça de Boi) APA do Parque Nacional da Serra do Cipó: Mata do Cachoeirão, 19²5'54.7"'S-43²5'58.3"W, 18.XII.2007, M.F. Santos \& L.M. Borges 207, bot. (SPF, SPFR); 19²5'55.7"S-4326'05.6"W, 1035m, 28.V.2010, K.F. Silva et al. 180 (SPFR).

Material adicional examinado: Bahia, VI.1832, L. Riedel 510, fl. (NY: tipo de Allophylus petiolulatus Radlk.); São Paulo, São Paulo: Parque Santos Dias, 2339'47"S-4646'21 "W, borda de capoeira, 16.VI.1992, R.J.F Garcia 73, fr. (SPF, PMSP); nativa no Jardim Botânico, 15.Ill.1939, O. Handro $s / n^{\circ}$, fl. ô (SP, SPF).

Ocorre na América do Sul, Bolívia e Brasil (Ferrucci et al. 2009), no Nordeste, Sudeste nos estados do Rio de Janeiro, São Paulo e Sul nos estados do Paraná e Santa Catarina; no Brasil é encontrada na Mata Atlântica (Somner et al. 2010); na Serra do Cipó, esta espécie possui apenas duas coletas e está aparentemente isolada na porção leste em Mata Estacional Semidecídua, os únicos registros de ocorrência de A. petiolulatus para 0 estado de Minas Gerais, são o do presente trabalho e Radlkofer (1931-1934), que cita a espécie como rara para Minas Gerais com apenas um exemplar de Luschnath (Aldea de Lagoa, Aug. 1834, flor, Hb. Mart., Ber.). Na Serra do Cipó foi coletada com botão (florescendo) em dezembro.

Allophylus petiolulatus foi identificada principalmente pelos 2 ramos na base da inflorescência, e pode ser confundida com A. edulis (A. St.-Hil.et al.) Niederl. por causa dos folíolos lanceolados, glabros, margem serreada no terço superior e frutos obovoides, porém distingue-se principalmente pelos 2 ramos supracitados e pelo peciólulo do folíolo terminal sempre notável. Allophylus edulis embora ocorra em Minas Gerais, não foi encontrada na Serra do Cipó. 
1.2. Allophylus sericeus (Cambess.) Radlk., Sitzungsber. Math.-Phys. Cl. Königl. Bayer. Akad. Wiss. München. 20: 230, 1890.

Prancha 1, fig. B-C.

Árvore 4-7m alt., ramos denso hirsuto-pubescentes, indumento amarelado. Folhas opacas, pecíolo 1,8-7,5 cm compr., subcilíndrico, complanado na face adaxial, peciólulo 1-4 mm compr.; folíolos 5,3-10 x 2,6$5,4 \mathrm{~cm}$, oval-lanceolados ou oboval-lanceolados, levemente romboidais, subcartáceos, ápice agudo, acuminado, mucronado, serreados ou serrilhados, folíolos laterais assimétricos, base oblíqua nos folíolos laterais, cuneada no folíolo terminal, face adaxial hirsuta-pubescente principalmente na nervura média, face abaxial pubescente, domácias barbadas, venação craspedódroma simples. Tirso simples, axilar, 2-5 cm compr., hirsutopubescente, cincinos 2-3-floros, brácteas e bractéolas 1-2 mm compr., pubescentes. Flores 3-4 mm compr., sépalas 1,5-2 mm, ovoides ou elípticas, face abaxial hirsuta, face adaxial glabra ou puberula, margem ciliada; pétalas 2,5-3 mm compr., glandulosas; disco nectarífero 4-lobado, lobos sub retangulares, quadrangulares ou hemidisco; flor $\widehat{\jmath}$ : estames ca. 2,5 mm compr., filetes cilíndricos, base vilosa, anteras pubérulas, pistilódio glabro; flor \%: estaminódios ca. $1 \mathrm{~mm}$ compr., ovário obovoide, piloso, estilete $2 \mathrm{~mm}$ compr. Frutos 7-8 x 6-7 mm, arredondados, epicarpo rugoso, tricomas setosos, brancos. Semente ovoide, $4 \times 3 \mathrm{~mm}$.

Material examinado: Minas Gerais, Santana do Riacho, Serra do Cipó: km 133 (atual 131) ao longo da rodovia Belo Horizonte-Conceição do Mato Dentro, 02.III.1981, M.C. Amaral et al. CFSC 7136, fr. jov. (CTES, SPF); km 104,

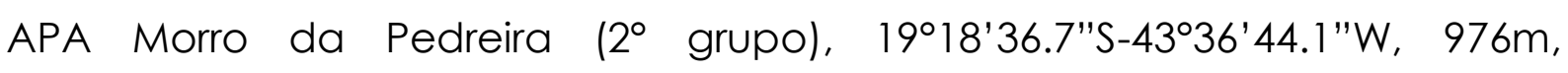
31.V.2010, K.F. Silva et al. 207 (SPFR).

Material adicional examinado: Minas Gerais: Matozinhos, Fazenda Cauaia, afloramento de calcário, 31.X.1996, J.A. Lombardi 1441, fl. đ̊ (BHCB, SPF); Iguatama: Fazenda Faroeste, margem esquerda do Rio São Miguel, 2015'23"S-4540'09"W, 16.XI.2002, P.H.A. Melo \& L.M. Versieux 244, fl. q (ESA, 
BHCB); Arcos: margem direita do Rio São Miguel, 20¹5'23"'S-4540'09"W, 16.XI.2002, P.H.A. Melo \& L.M. Versieux 257, fl. o (ESA, BHCB).

Ocorre na Bahia, Goiás, Distrito Federal, Minas Gerais, Rio de Janeiro e São Paulo, em mata mesófila semidecídua e mata latifoliada de Araucária (Ferrucci et al. 2009, Somner et al. 2010); na Serra do Cipó parece ser rara, com apenas um indivíduo na APA Morro da Pedreira, foi coletada apenas em estado vegetativo.

Allophylus sericeus foi identificada principalmente pelos folíolos hirsutopubescentes, margem serrilhada e folíolos laterais assimétricos. É morfologicamente afim a A. semidentatus (Miq.) Radlk., o que as diferem são os caracteres supracitados para A. sericeus enquanto A. semidentatus possui folíolos pubescentes ou glabriúsculos, glandulosos, margem no 1/2 superior denteada-serreada, base especialmente no folíolo intermediário cuneada. A. semidentatus embora ocorra em Minas Gerais, não foi encontrada na Serra do Cipó.

\section{Cardiospermum L.}

Trepadeiras herbáceas ou hemicriptófitas rizomatosas, raro ervas eretas, monoicas, glabras a pubescentes, indumento branco-amarelado; caule simples. Folhas imparipinadas, alternas, biternadas, folíolos basais 3foliolulados, menos frequente 3 ou 5 folioladas, pecíolo e raque bicanaliculados; estípulas triangulares; folíolos denteado-serreados ou incisodenteados, peciolulados; domácias geralmente presentes. Tirso simples, axilar, cincinos geralmente pedunculados, gavinhas na base da raque da inflorescência. Flores zigomorfas, esbranquiçadas, pediceladas, cálice 4-5mero, dialissépalo, sépalas cuculadas, oblongas, ovadas ou obovadas, persistentes no fruto, externas menores que as internas; corola 4-mera, pétalas obovadas, ungüiculadas, glandulosas, apêndice basal petaloide, ciliado com crista apical carnosa e amarelada, simétrico nas pétalas 
posteriores e assimétrico nas anteriores; nectários unilateral; androginóforo pubérulo; flor đ̂: estames desiguais, exertos, pistilódio curto; flor p: gineceu 3carpelar, 1 óvulo por carpelo, estigma 3-fido. Cápsula septífraga, geralmente estipitada, globosa, lóculos inflados, paredes do septo duplas, membranáceas; epicarpo glabro a pubescente, endocarpo geralmente glabro. Sementes geralmente subesféricas, tegumento ósseo ou crustáceo, preto-azuladas ou castanhas, arilo geralmente seco.

Gênero pantropical com 14 espécies, 3 delas de ampla distribuição: C. corindum L., C. grandiflorum Sw. e C. halicacabum L. (Ferrucci 1991, 2000, 2009). No Brasil vivem 10 espécies, sendo 5 endêmicas (Ferrucci 2000, Somner et al. 2010). Sua distribuição altitudinal varia entre o nível do mar e $2600 \mathrm{~m}$ de elevação (Ferrucci 2000). Ocorre ao longo da região neotropical, com o principal centro de diversidade de espécies no centro e oeste do Brasil (Ferrucci 2000; Solís \& Ferrucci 2006). Na Serra do Cipó ocorre apenas uma espécie.

O nome Cardiospermum deriva do grego cárdia=coração e sperma=semente, em alusão ao arilo seco cordiforme das sementes destas plantas (Ferrucci 2000). O gênero é reconhecido por suas cápsulas infladas, ápteras ou estreitamente aladas (Ferrucci 2000).

\subsection{Cardiospermum grandiflorum SW., Prodr. 64. 1788.}

Prancha 1, fig. D-E.

Ramos 5-6 costados ou estriados, alguns fistulosos. Folhas: pecíolo 1-3,5 cm compr., estípula 0,7-3 mm compr.; folíolos 1,3-7,2 x 0,7-3,8 cm, ovais, discolores, cartáceos, ápice agudo ou acuminado, mucronado, geralmente com glândula marginal, base decurrente no folíolo terminal, cuneada ou assimétrica nos folíolos laterais, pubescentes, tricomas glandulares espalhados, venação craspedódroma ou semicraspedódroma; domácias barbadas ou em bolsas. Tirso racemiforme, ca. $15 \mathrm{~cm}$ compr., cincinos 3-(4)floros, brácteas e bractéolas 1-3 mm compr., triangular-subuladas, 
pubescentes. Flores 5-9 mm, sépalas 2-8 × 2-6 mm, pilosas ou glabras na face abaxial, glabras na face adaxial, tricomas glandulares na margem; pétalas 5 x $4 \mathrm{~mm}$, tricomas glandulares espalhados na face adaxial, glabras na face abaxial, apêndice petaloide com escama basal pilosa, ápice com crista inteira ou erosa; 2 lobos nectaríferos corniculiformes, $2 \mathrm{~mm}$. compr., glabros ou pubérulos; flor 3 : estames 3-5 mm compr., filetes achatados, glabros ou pubescentes, anteras glabras, pistilódio pubérulo; flor p: estaminódios $2 \mathrm{~mm}$, ovário ovoide, pubescente. Cápsula trígona-ovoide ou -elipsoide, não alada, castanha-clara, 3,2-5,3 x 2,1-3,5 cm, estípite $3 \mathrm{~mm}$ compr., epicarpo pubescente ou glabro, endocarpo brilhante; sementes esféricas, arilo seco.

Material examinado: Minas Gerais, Santana do Riacho, Serra do Cipó: rodovia MG-010, Belo Horizonte-Conceição do Mato Dentro, Cardeal Mota, Morro do Calcário, 2.III.1981, M.C. Amaral et al., CFSC 7227, fl. ふૈ. fr. (SPF, SPFR); APA Morro da Pedreira, 21.IV.1990, B.Q. Andrade 17565, fl. §̊, fr. (BHCB); estrada para a trilha do Morro da Pedreira $3^{\circ}$ grupo, $19^{\circ} 18^{\prime} \mathrm{S}-43^{\circ} 36^{\prime} \mathrm{W}, 935 \mathrm{~m}$, 17.VI.2007, K.F. Silva et al. 37, fl ô, o, fr. (BHCB, CTES, RB, SPF, SPFR).

Distribui-se na África Oriental e Central, Austrália e Américas, desde o Panamá até o centro da Argentina ao Uruguai. No Brasil ocorre no Pará, Amazonas, Rondônia, Maranhão, Rio Grande do Norte, Goiás, Distrito Federal, Mato Grosso do Sul, Minas Gerais, Espírito Santo, São Paulo, Rio de Janeiro, Paraná, Santa Catarina e Rio Grande do Sul (Ferrucci 1991, 2000, 2009; Somner et al. 2010). Vegeta em borda de mata, de mata alta perenifólia a decídua e seca, também em vegetação de borda secundária (Ferrucci 2000). Na Serra do Cipó foi encontrada principalmente em áreas perturbadas, como borda de estrada, corroborando com informações em (Ferrucci 1991, 2000); coletada com flor e fruto nos meses de março, maio e junho.

Cardiospermum grandiflorum foi identificada principalmente por possuir dois lobos nectaríferos corniculiformes e cápsula não alada. É morfologicamente afim a C. integerrimum Radlk. e C. heringeri Ferrucci, diferindo das mesmas por possuir cálice 4-mero e cápsula áptera, enquanto 
as duas possuem cálice 5-meros e cápsulas aladas (Ferrucci 2000). Cardiospermum integerrimum ocorre na Bahia (Ferrucci 2000, Somner et al. 2010) e C. heringeri no sudeste do Brasil (Ferrucci 2000, Somner et al. 2010), e embora ocorra em Minas Gerais, não foi encontrada na Serra do Cipó.

\section{Cupania L.}

Árvores ou arbustos, monoicos; córtex escamoso ou não, castanho ou acinzentado, ramos cilíndricos ou sulcados, estriados, glabros ou com indumento, lenticelados. Folhas paripinadas, alternas; folíolos peciolulados ou sésseis, alternos, opostos ou subopostos, cartáceos, subcoriáceos ou coriáceos, concolores ou discolores, margem denteada, serreada, repandodenteada ou inteira, subrevoluta, nervação semicraspedódroma ou eucamptódroma; domácias presentes ou ausentes. Tirso duplo, raro simples, axilar ou subterminal; dicásios ou cincinos, às vezes glomeruliformes, pedunculados ou sésseis; brácteas e bractéolas presentes, persistentes. Flores actinomorfas; cálice 5-mero, dialissépalo, sépalas cuculadas, ovadas; corola 4-5-mera, pétalas ungüiculadas, disco nectarífero completo, glabro; flor $\delta^{*}$ : estames exertos; flor o: gineceu com ovário 2-3-carpelar, ovário 2-3-locular, 1 óvulo por carpelo, estilete filiforme, estigma 2-3-fido ou com lóbulos concrescentes. Cápsula loculicida, turbinada, trígona ou trilobada, obtriangular ou obcordada, curto estipitada, coriácea. Sementes brilhantes, lisas, elipsoides, arilo carnoso, branco ou alaranjado.

O gênero Cupania estende-se desde o México até a Argentina e Uruguai (Somner et al. 2009), com aproximadamente 65 espécies (Guarim Neto 1985). No Brasil ocorrem 31 espécies, sendo 24 endêmicas, encontradas em quase todos os estados, em diversos ambientes e tipos vegetacionais (Somner et al. 2010).

Na Serra do Cipó ocorrem 4 espécies. 
O gênero Cupania principalmente em estado vegetativo é facilmente confundindo com o gênero Matayba, e ambos são muito difíceis para identificar. Radlkofer (1933), Croat (1976), Guarim Neto (1985) e Somner \& Ferrucci (2004), citam como características diagnósticas, para reconhecimento de ambos gêneros, as sépalas, que no gênero Cupania são livres e no gênero Matayba são unidas. No entanto, o principal carater para separar Cupania de Matayba é que as espécies deste último gênero apresentam abertura precoce do cálice, de modo que no botão floral ficam expostos os outros verticilos da flor. Segundo Coelho (2008), os dois gêneros podem ser também separados através da análise criteriosa da rede de nervuras, que em Cupania é mais evidente e reticulada, sendo mais delgada e delicada em Matayba.

\section{Chave para as espécies de Cupania}

1.Folíolos com margem inteira; cápsula obtriangular, achatada lateralmente, 2-locular. 3.1. C. Iudowigii l'.Folíolos com margem denteado-serreada, serreada ou repandodenteada; cápsula trígona, não achatada lateralmente, 3-locular.

2.Folíolos com margem denteado-serreada. 3.4. C. vernalis 2 '.Folíolos com margem repando-denteada ou serreada.

3.Margem com dentes não mucronados, terciárias percorrentes, domácias urceoladas e barbadas. ..3.2. C. moraesiana 3'.Margem com dentes mucronados, terciárias reticuladas, domácias ausentes. 3.3. C. paniculata 
3.1. Cupania ludowigii Somner \& Ferrucci, Bot. J. Linn. Soc. 146(2): 217-221. 2004.

Prancha 1, fig. F-H.

Árvores 9-22m alt., ramos subcilíndricos, com fissuras superficiais, glabros ou pubérulos, castanhos; lenticelas verrucosas. Folhas: pecíolo 1,8-4,5 cm compr. e raque estriados, face adaxial complanados ou bicanaliculados, pubérulos ou pubescentes, peciólulo 1-3 mm; folíolos (2)3-6 pares, 2,5-8 × 1,22,9 cm, alternos, subopostos, elípticos ou obovados, cartáceos ou subcoriáceos, discolores, ápice agudo, arredondado retuso ou emarginado, margem inteira, ondulada, revoluta, base aguda, cuneada ou arredondada; face adaxial glabra ou com poucos tricomas adpressos, nervura média impressa, face abaxial glabrescente, pilosa nas nervuras, nervação broquidódroma, terciárias reticuladas; domácias foveoladas. Tirso duplo, axilar ou terminal, 7-11 cm compr., pubescente, cincinos 1-3-floros, curto pedunculados; brácteas e bractéolas ca. $1 \mathrm{~mm}$ compr., triangulares. Flores ca. $4 \mathrm{~mm}$, branco-amareladas, sépalas $2 \times 1,5 \mathrm{~mm}$, oblongas ou obovadas, pubérulas ou pubescentes, margem vilosa, corola 5-mera, pétalas $2 \times 1,5$ $\mathrm{mm}$, espatuladas, glandulosas, apêndice petaloide com ápice bipartido, viloso, disco nectarífero inteiro, anelar; flor ${ }^{\hat{*}}$ : estames $3-4 \mathrm{~mm}$, filetes cilíndricos, pubescentes até o meio, flor o: estaminódios $2 \mathrm{~mm}$, pubescentes, ovário obovoide, pubescente. Cápsula 1,5-2,3 x 1,3-2,2 cm, obtriangular, achatada lateralmente, emarginada, 2-locular, estípite 2-4 mm, epicarpo glabro, endocarpo piloso na região do septo; sementes 1-2, 1,3 $0,6 \mathrm{~cm}$, arilo alaranjado cobrindo $2 / 3$ da semente.

Material examinado: Minas Gerais: Itambé do Mato Dentro, distrito de Santana do Rio Preto (Cabeça de Boi), APA do Parque Nacional da Serra do Cipó, 19²3' 49.2"S-4324'05.8"W, 24.VIII.2007, M.F. Santos \& E.G. Martins 140, fr. (SPF, SPFR); 19023'51.3"S-4324'06.2"W, 708m, 28.V.2010, K.F. Silva et al. 170, fr. ( 
BHCB, CTES, SPF, SPFR); Santana do Riacho, Serra do Cipó, km 129,5 da rodovia MG-010, 19¹3'47.1"S-4330'28.9"W, 1358m, 18.Il.2010, K.F. Silva \& T.P. Martins 149, fr. jov. (BHCB, CTES, RB, SPF, SPFR).

Material adicional examinado: Rio de Janeiro, Resende, Itatiaia National Park, main road, 15.VIII.1998, J.M. Braga et al. 4912 fr. (CTES, isótipo!; São Paulo, São José do Barreiro: Fazenda Atibaia. 22³8'19"S-44³9'41.2"W, 13.I.2008, H. Serafim 110, fl. $\hat{\jmath}$, o (SPF).

Espécie endêmica do Brasil, ocorre nos estados da Bahia, Espírito Santo, Minas Gerais, Rio de Janeiro e São Paulo (Somner \& Ferrucci 2004, Somner et al. 2009, 2010); cresce na Mata Atlântica e nas matas de galeria incluídas na vegetação de campos rupestres, ocorrendo em solos hidromórficos pedregosos a uma altitude de 660-1100 m.s.m. (Somner \& Ferrucci 2004). Na Serra do Cipó foi encontrado um indivíduo em mata de galeria em área de campo rupestre e uma população na porção leste em Mata Estacional Semidecídua; coletada com frutos em fevereiro, maio e agosto.

Cupania ludowigii foi identificada principalmente pelas folhas 6-13 folioladas, domácias presentes e arilo laranja cobrindo $2 / 3$ da semente. E segundo Somner \& Ferrucci (2004), é morfologicamente afim a C. emarginata, diferindo principalmente pelos caracteres supracitados e ocorrrência em Mata Atlântica e matas de galeria em formações de campo rupestre, enquanto C. emarginata é 4-8 foliolada, as domácias ausentes, o arilo branco cobre toda a semente e é restrita a restinga.

\subsection{Cupania moraesiana Guarim Eugeniana 20: 7-15. 1993.}

Prancha 1, fig. J-K.

Árvore ou arbusto 0,5-9 m. alt., ramos levemente sulcados, estriados, tomentoso-vilosos, indumento amarelo-ferrugíneo, córtex escamoso; lenticelas lineares e verrucosas. Folhas: pecíolo 1,5-2,5 cm compr. e raque estriados, canaliculados, face adaxial complanada, pubescentes, peciólulo 
0-1 mm; folíolos 3-7 pares, 2,5-8,5 x 1,7-4,7 cm, alternos ou subopostos, elípticos, oblongos ou obovados, subcoriáceos, discolores, ápice obtuso ou retuso, mucronulado, margem repando-denteada em $2 / 3$ da lâmina ou serreada nos ramos mais jovens, subrevoluta, base aguda ou cuneada, levemente assimétrica; face adaxial brilhante, glabra ou pilosa, tomentosa sobre as nervuras, nervura média impressa, face abaxial opaca, hirsutotomentosa; nervação craspedódroma, secundárias não ultrapassam a margem do limbo, terciárias percorrentes; domácias urceoladas e barbadas. Tirso duplo, axilar, ca. $30 \mathrm{~cm}$ compr., pubescente, parciais cimosas, pedunculadas ou cincinos sésseis; brácteas e bractéolas 2-4 mm compr., subuladas, tomentosas. Flores (retirado de Guarim Neto 1985): 5 mm compr., bracteoladas, bractéolas hirsutas, sépalas oblongas, hirteloides externamente, glabras internamente, pétalas 5, ligeiramente flabeliformes, glabras externa e internamente; estames 8, levemente achatados e pouco pilosos; ovários trígonos, densamente hirsutos. Frutos (retirado de Guarim Neto 1985): hirsutos.

Material examinado: Minas Gerais: Itambé do Mato Dentro. Distrito de Santana do Rio Preto (Cabeça de Boi), 19²3'46.9"S-4324'07.4"W, 16.III.2008, M.F. Santos \& H. Serafim 331, bot. (SPF, SPFR); Distrito de São José da Cachoeira, Santana do Pirapama (Serra da Lapa), Serra do Cipó, trilha sentido base da Serra, 1859'53.6"'S-4346'01.7"W, 749m, 05.II.2009, K.F. Silva et al. 105 (CTES, SPFR).

Material adicional examinado: Minas Gerais, Paracatu, Rod. Bras. B.H., 27.VII.61, E.P. Heringer 8550/744, fl. (US, foto do parátipo de Cupania moraesiana Guarim).

Espécie restrita ao estado de Minas Gerais (Guarim Neto 1993, Somner et al. 2010). Característica de áreas de cerrado (Guarim Neto 1993). Na Serra do Cipó foi encontrado um indivíduo na porção leste, sendo essa a primeira ocorrência da espécie em Mata Estacional Semidecídua e outro na porção oeste, em área de cerrado; coletada com botões em março. 
Cupania moraesiana foi identificada por caracteres distintos como folíolos coriáceos, nervuras terciárias percorrentes, domácias urceoladas, barbadas e tirso com ca. $30 \mathrm{~cm}$ compr. Cupania moraesiana é morfologicamente afim a C. paniculata, diferindo pelos caracteres supracitados, enquanto C. paniculata possui nervuras terciárias reticuladas, domácias ausentes e tirso com até $10 \mathrm{~cm}$ compr. Cupania moraesiana ainda pode ser confundida com Cupania rigida, mais segundo (Radlkofer 1933, Somner et al. 2010), C. rigida não ocorre em Minas Gerais.

3.3. Cupania paniculata Cambess., Fl. Bras. Merid. 1: 388, 1828.

Prancha 1, fig. I.

Árvore ou arbusto 0,60-3m alt., ramos sulcados, pubescentes ou tomentosos, ferrugíneos, lenticelas lineares ou verrucosas. Folhas: pecíolo 1,5$6,6 \mathrm{~cm}$ compr. e raque estriados, face adaxial complanados, vilosos, peciólulo $1 \mathrm{~mm}$; folíolos (2)3-5(6) pares, 3,5-11,5 × 2-6 cm, alternos ou subopostos, elípticos ou obovados, coriáceos, discolores, ápice arredondado, obtuso ou retuso, margem repando-denteada ou serreada, mucronada, subrevoluta, base atenuada, levemente assimétrica, menos freqüente aguda; face adaxial brilhante, glabra a pilosa, nervura média plana, margem velutina, face abaxial opaca, denso tomentosa-pubescente, hirsuta; nervação craspedódroma ou semicraspedódroma, secundárias ultrapassam a margem do limbo, terciárias reticuladas; domácias ausentes. Tirso duplo, raro simples, axilar ou subterminal, 2,5-10 cm compr., viloso; inflorescências parciais glomeruliformes, 3-floros, pedunculadas, brácteas e bractéolas 1-4 mm compr., lanceolada-subuladas, vilosas. Flores $4 \times 3 \mathrm{~mm}$, cremes, sépalas $2 \times 1 \mathrm{~mm}$, pubescentes, tomentosas, coriáceas; pétalas 4,2 x $1 \mathrm{~mm}$, pubescentes, apêndice petalóide basal bipartido, viloso; disco nectarífero inteiro ou lobado, glabro; flor 3 : estames $2-4 \mathrm{~mm}$, filetes filiformes, pubescentes até 2/3; flor 0 : gineceu 3-carpelar, ovário trígono, tomentoso, estigma clavado, breve 3-partido, glanduloso. Cápsula turbinada ou 
trilobada, 1-1,7 x 0,9-1,3 cm, estípite 2-5 mm, epicarpo e endocarpo tomentosos ou velutinos; sementes $1 \times 0,5 \mathrm{~cm}$, arilo alaranjado cobrindo metade da semente.

Material examinado: Minas Gerais, Distrito de São José da Cachoeira, Santana do Pirapama (Serra da Lapa), Serra do Cipó, trilha da Senhorinha:

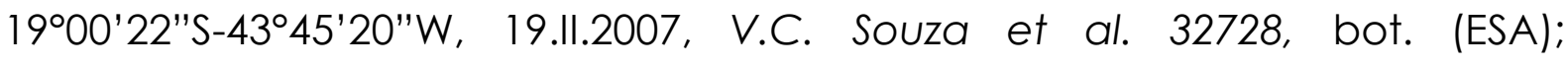
1857'51.6"S-4346'49.0"W, 704m, 06.III.2009, K.F. Silva et al. 118 (SPFR).

Material adicional examinado: Bahia: Pico das Almas, 133' S-415' W, 1400m, 20.III.1977, R.M. Harley 19744, fl. ô, fr. (SPF, K); Piatã, Três Morros, 24.VIII.2000, A.A. Conceição 887, fl. ô. q (SPF, K, F).

Espécie endêmica do Brasil, encontrada nos estados da Bahia e Minas Gerais: na Caatinga e no Cerrado (Somner et al. 2010), podendo ser encontrada também como heliófila (Ferrucci 2003). Na Serra do Cipó é restrita à Santana do Pirapama, no cerrado com solo arenoso; coletada em botão no mês de fevereiro.

Cupania paniculata foi identificada principalmente através dos folíolos coriáceos, margem repando-denteada ou serreada, face adaxial lustrosa, nervuras secundárias que ultrapassam a margem do limbo e frutos tomentosos ou velutinos. É morfologicamente afim a C. moraesiana cujas semelhanças e diferenças foram discutidas anteriormente.

\subsection{Cupania vernalis Cambess., Fl. Bras. Merid. 1: 387.1825.}

Prancha 1 , fig. L-M.

Árvores, arvoretas ou arbustos 4-9m alt., ramos sulcados, tomentosos, alvo-amarelados a ferrugíneos, córtex castanho ou acinzentado; lenticelas lineares ou verrucosas. Folhas: pecíolo $3-10 \mathrm{~cm}$ compr., e raque estriados, glabros a hirsuto-tomentosos, peciólulo 1-4 mm; folíolos 3-10 pares, 3-21 × 2,6-7 cm, alternos, opostos ou subopostos, obovados, oblongos, elípticos, cartáceos a subcoriáceos, concolores, ápice agudo ou obtuso, retuso, margem denteada-serreada, base obtusa, aguda, arredondada ou 
levemente assimétrica; face adaxial, glabra, nervura média impressa, face abaxial hirsuta principalmente nas nervuras; nervação craspedódroma, terciárias reticuladas; domácias urceoladas ou barbadas. Tirso simples ou duplo, axilar ou subterminal, 15-30 cm compr., tomentoso; cincinos 1-3-floros, pedunculados, brácteas e bractéolas 1-4 mm compr., pubescentes. Flores cremes, 2-4 mm, sépalas pubescentes, tomentosas; pétalas 5, glabras, margem vilosa, apêndice basal petaloide bipartido, inflexo, viloso; disco nectarífero inteiro, anelar, glabro; flor ${ }^{*}$ : estames $5 \mathrm{~mm}$, filetes hirsutos, vilosos até 2/3; flor + : gineceu 3-carpelar, ovário piriforme ou ovoide, pubescentetomentoso, ramos do estigma concrescentes. Cápsula trígono-obovoide, 1,41,7 x 1,2-1,5 cm, estípite 1-2 mm, epicarpo rugoso, coriáceo, pubescente, endocarpo viloso; sementes 0,8-1,5 x 0,4-1 cm, castanho-escuro, arilo alaranjado, cobrindo $1 / 2^{-2} / 3$ da semente.

Material examinado: Minas Gerais, Santana do Riacho, Serra do Cipó: ao longo da rodovia Belo Horizonte-Conceição do Mato Dentro, km 105 , 26.V.1980, A. Furlan CFSC 6152, fr. (SPF, SPFR); local, data e número de coleta igual ao anterior, coletores diferentes: idem, I.Cordeiro \& J.R. Pirani CFSC 6152, fr. (SP, SPF); idem km 103, 19¹8.3'7"S-43³6'4.1"W, 1076m, 16.VI.2007, K.F. Silva \& R.F. Oliani 30 (SPFR); Km 104, Morro da Pedreira: (2० grupo),

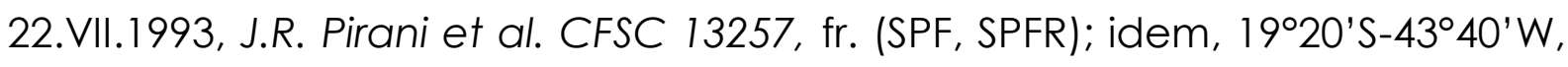

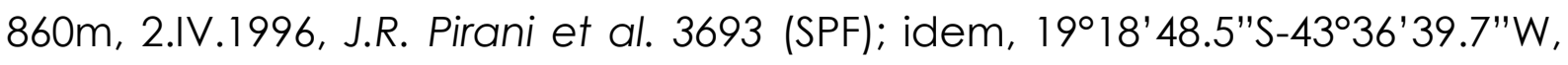

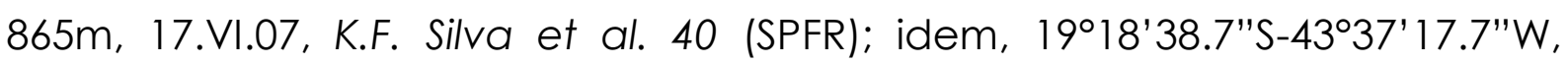
1318m, 24.IX.2007, K.F. Silva et al. 64, fr. (BHCB, CEPEC, CTES, MBM, RB, SPF,

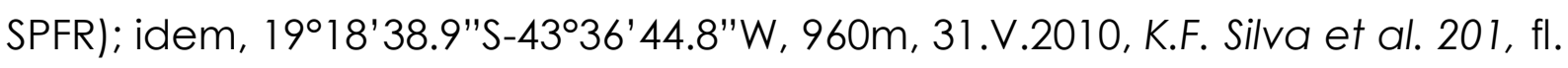

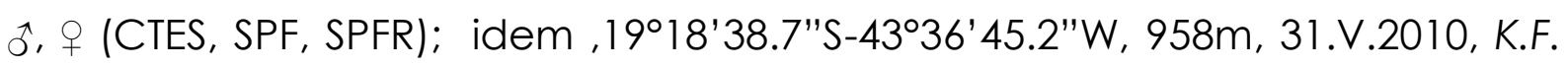
Silva 202 et al., fl. ô. + (CTES, SPF, SPFR); idem (3० grupo), 19¹8.3'59.1"S433'00.4"W, 863m, 02.IX.2008, K.F. Silva \& R.F. Oliani 98, fr. (SPF, SPFR); Jaboticatubas: km 93 da MG-010, estrada de terra ao lado do Córrego João Congo, 19²2' 43.9"'S-4339'35.4"W, 816m, 02.IX.2008, K.F. Silva \& R.F. Oliani 94, fr. (BHCB, CTES, RB, SPF, SPFR); Estrada de terra sentido distrito de Santana do Riacho, 19¹6'46.6"S-4338'30.8"W, 745m, 20.II.2010, K.F. Silva \& T.P. Martins 158 (SPFR); Itambé do Mato Dentro. Distrito de Santana do Rio Preto (Cabeça de 


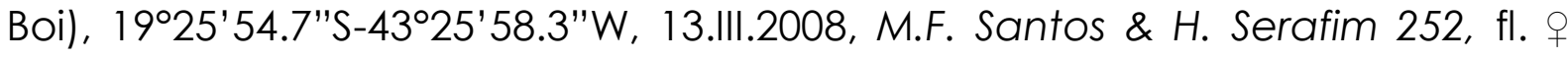
(SPF, SPFR); idem, $19^{\circ} 23^{\prime} 51.6^{\prime \prime} \mathrm{S}-43^{\circ} 24^{\prime} 07.0^{\prime \prime} \mathrm{W}, 702 \mathrm{~m}, 28 . V .2010$, K.F. Silva et al. 173 (SPFR); idem, 19²4'16.6"S-4324'41.5"W, $711 \mathrm{~m}, 28 . V .2010$, K.F. Silva 178 et al. frutificando (CTES, RB, SPF); idem, Mata do Cachoeirão, 19²5'55.7"S4326'05.6"W, 1033m, 28.V.2010, K.F. Silva 186 et al. fr. (BHCB, SPF, SPFR).

Material adicional examinado: Brasil, 1816-21, St.-Hilaire s.n., fr. (P, foto F, negativo 36017!); São Paulo, Cruzeiro, Fazenda Boa Vista, 22²9'03"S4301'37"W, 1100m, 05.IV.1995, R. Goldenberg \& J.L.A. Moreira 56, fl. ô, ㅇ (UEC).

No Brasil ocorre nos estados do Pará, Amazonas, Bahia, Goiás, Distrito Federal, Minas Gerais, Espírito Santo, São Paulo, Rio de Janeiro, Paraná, Santa Catarina e Rio Grande do Sul (Somner et al. 2010), segundo (Guarim Neto 1985), Cupania vernalis pode ser encontrada em formações amazônicas de matas de terra firme, de várzea, de igapó e capoeiras e nas extra amazônicas é encontrada nas matas, nos cerrados (s.l.), no pantanal, nas restingas, nas capoeiras e nas matas de encosta, como um elemento importante nessas formações. Atinge outras áreas sul-americanas, como a Bolívia, o Paraguai, o Uruguai e a Argentina. Sua madeira é utilizada para a confecção de cercas, cabos de ferramentas, etc. e suas folhas servem de alimento para os bugios (Somner et al. 2009). Na Serra do Cipó foi coletada em mata de galeria, capoeira, mata decídua e em afloramento calcáreo; coletada com frutos em maio e setembro e flor em março.

Cupania vernalis foi facilmente identificada pelos folíolos com margem serreada-denteada, inflorescência $15-30 \mathrm{~cm}$ compr. e frutos pubescentes. É morfologicamente afim a Cupania zanthoxyloides diferindo principalmente pelos caracteres supracitados enquanto C. zanthoxyloides possui folíolos com margem repando-denteada, inflorescência ca. $10 \mathrm{~cm}$ compr. e frutos negros, glabrescentes. 


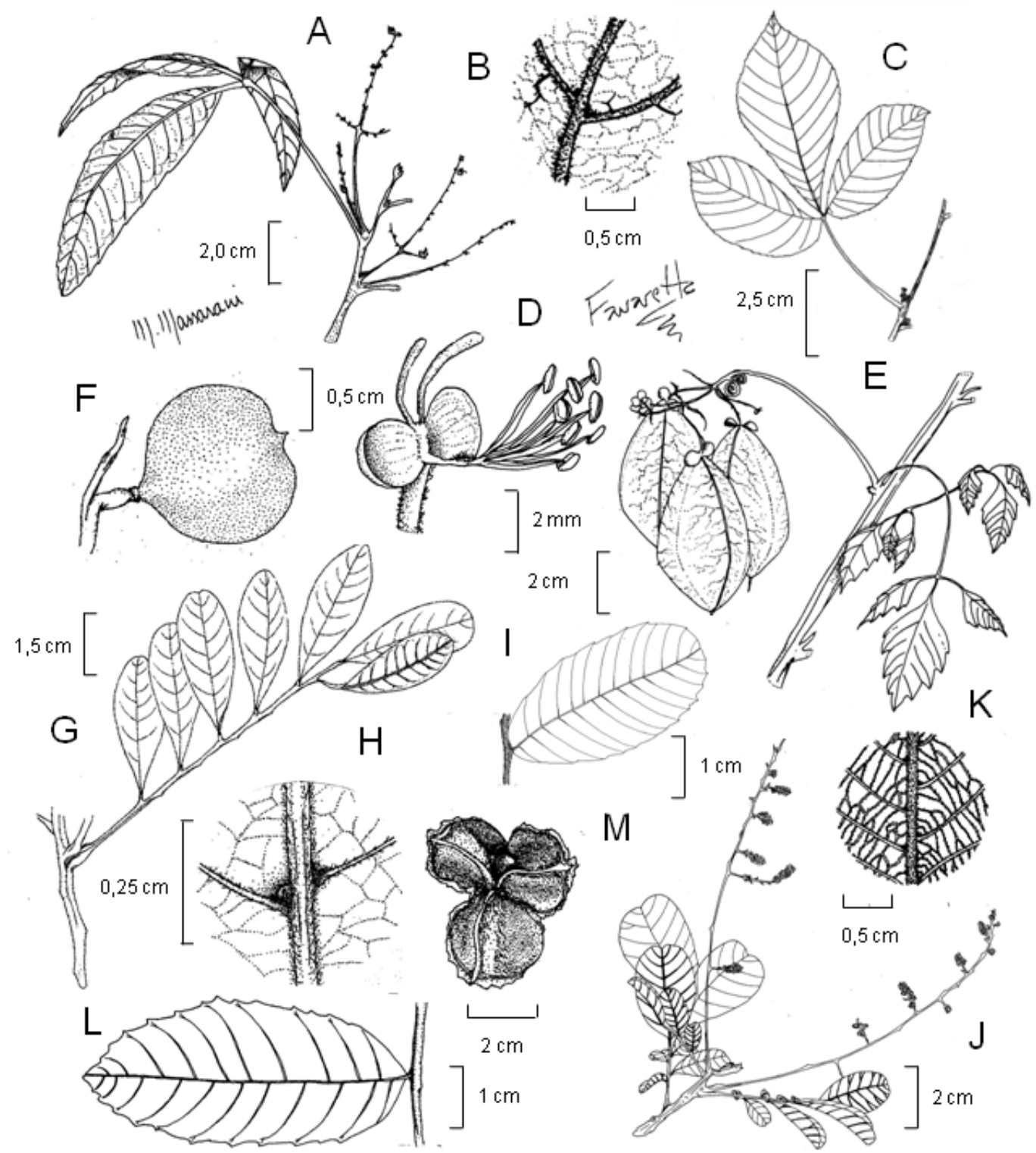

Prancha 1. A. Allophylus petiolulatus, ram o florifero. B-C. Allophylus sericeus, B. detalhe da face abaxial do folíolo mostrando domácias barbadas; C. folha. D-E.Cardiospermum grandiflorum, D. flor m asculina, evidenciando os lobos nectaríf eros corniculif ormes, 2 sépalas e todas as pétalas foram retiradas; E. ramo frutifero. F-H. Cupania ludowigii, F. fruto; G. ramo; H. detalle da face abaxial do foliolo mostrando domácias foveoladas. I. Cuparia paniculata, foliolo. J-K. Cupania moraesiana, J. ramo florífero; K. detalhe da face abaxial do foliolo mostrando as nervuras secundárias percorrentes. L-M. Cupania vernalis, L. foliolo; M. fruto aberto. (A-B, Silva et al. 207; C, Santos \& Borges 207; D-E, Silva et al 37; F-H, Silva et al. 170 ; I, Silva et al. 118 ; J-K, Santos \& Serafim 331; L-M, Silva et al. 64.) Ilustrações: AE: Favaretto; F-M:Massarani. 


\section{Dilodendron Radlk.}

Árvores dioicas, ramos estriados, levemente sulcados, lenticelados. Folhas alternas, bipinadas; folíolos alternos, paripinados, foliólulos alternos, subopostos ou opostos, peciolulados ou sésseis, crenado-serreados, domácias ausentes, estípulas ausentes. Tirso duplo, axilar ou terminal; cincinos 3-4 floros, curto pedunculados; brácteas e bractéolas ovado-agudas, decíduas, tomentoso-pubescentes. Flores actinomorfas, verde-amareladas; cálice 5-mero, dialissépalo, sépalas cuculadas, ovadas, glabras, pilosas, tricomas glandulares, persistentes no fruto; corola 3-5-mera, na flor estaminada às vezes ausente; apêndice petaloide com escama basal ausente o rudimentar; disco nectarífero inteiro; androceu: filetes cilindricos, glabros, anteras com tricomas glandulares e simples, pilosas; gineceu: ovário trígono, ovoide ou obovoide, 1 óvulo por carpelo, estilete filiforme, estigma 3 lobado, lobos concrescentes. Cápsula loculicida, 2-3 lobada, 2-3 valvar, valvas lenhosas; sementes castanho-escuras, obovoides ou elipsoides, testa brilhante, arilo carnoso, branco.

O gênero é constituído de 3 espécies sendo $D$. bipinnatum principalmente das áreas secas subequatoriais do escudo Brasileiro e regiões adjacentes, D. costaricense do norte da América do Sul extendendo em direção ao sul da América Central e D.elegans muito difundido da Costa Rica a Venezuela e Amazonia peruana (Gentry \& Steyermark 1987). Na Serra do Cipó ocorre uma espécie.

De acordo com a revisão realizada por Gentry \& Steyermark (1987), o gênero Dilodendron é morfologicamente afim aos gêneros Cupania e Matayba, diferindo de ambos notavelmente pelas folhas bipinadas. As espécies dioicas e o apêndice petaloide ausente em Dilodendron também o diferem dos gêneros mencionados acima. 
4.1. Dilodendron bipinnatum Radlk., Sitzungsber.Math.- Phys. Cl. Königl. Bayer. Akad. Wiss. München 8: 357. 1878.

Prancha 2, fig. A-B.

Árvore ou arbusto 0,50-10 m alt., ramos estriados ou levemente sulcados, pubescentes, indumento de tricomas ocráceos a esbranquiçados, lenticelas lineares. Folhas 4-8 (10) folioladas; pecíolo 0,5-3,4 cm compr., raque canaliculada, marginada próximo ao foliólulo terminal, peciólulos 1-2 mm ou séssil; foliólulos 1,5-7,5 × 0,5-2,9cm, elípticos, discolores, cartáceos, ápice agudo, obtuso ou acuminado, margem denteado-serreada, base oblíqua, obtusa ou arredondada, face adaxial pubérulo, pubescente, tomentoso na região da nervura média, face abaxial hirtelo-pubescente, principalmente na região das nervuras e margem, venação craspedódroma. Tirso $10-25 \mathrm{~cm}$ compr., pubérulo. Flores 4-5 mm, branco-esverdeadas, pedicelo 2-4 mm, sépalas $2 \times 2 \mathrm{~mm}$, face adaxial glabra, face abaxial pubérula, margem ciliada, glandulosa; pétalas 1,4-1,6 mm; disco nectarífero anelar, glabro; flor స: estames (6)-8, 3,5-4,5 mm compr., anteras com indumento glandular, pistilódio pubérulo, flor $q$ (não visualizada, retirado de Ferrucci 1991): gineceu $4 \mathrm{~mm}$, ovário e estilete glabriúsculos ou pubérulos. Fruto 1,5-2,5 x 0,9-2 cm, trígono-ovoides, 3-carpelar, epicarpo rugoso, glabro, endocarpo viloso; sementes $1 \times 0,5 \mathrm{~cm}$, obovoides, castanho-escuras, arilo carnoso esbranquiçado.

Material examinado: Minas Gerais, Santana do Riacho, Serra do Cipó: perto de Cardeal Mota, 2.III.1981, J.R. Pirani et al. CFSC 7127-A (CTES, SPF); APA Morro da Pedreira - 2० grupo, 19¹8'48.5"S-4336'39.7"W, 865m, 17.VI.2007, K.F. Silva et al. 43 (SPFR); APA Morro da Pedreira - $3^{\circ}$ grupo, 19018'59.1"S-4337'00.4"W, 863m, K.F. Silva \& R.F. Oliani 97 (SPFR); Santana de Pirapama: trecho de vazão reduzida, PCH Quartel III, 18³7'51.9"S4356'10.8"W, 7.VI.2007, D.T. Souza et al. 183, fl. đ (BHCB); Distrito de São José da Cachoeira (Inhame), Rio Cipó, 1857'35.6"S-4347'41.6"W, 633m, K.F. Silva et al. 113 (SPFR). 
Material adicional examinado: Minas Gerais, Matozinhos, Reserva legal PRECON, 19³0'27.9"'S-4352'56"W, 21.VI.2007, G.Q. Freire et al. 31 1, fr. (SPF).

Espécie distribuída pelo Peru, Bolívia, norte do Paraguai e no Brasil nos estados do Acre, Tocantins, Bahia, Goiás, Mato Groso, Mato Grosso do Sul, Minas Gerais, Rio de Janeiro e São Paulo: mata mesófila (Somner et al. 2009, 2010). Na Serra do Cipó foi encontrada em mata semidecídua e em mata ciliar; coletada com flores em junho.

Dilodendron bipinnaum foi facilmente identificada pela presença das folhas bipinadas. Gentry \& Steyermark (1987), difere D. bipinnatum das outras 2 espécies do gênero, D. costaricense e D. elegans, por apresentar a margem dos folíolos com dentes convexos, notavelmente ciliados, nervuras com indumento espalhados, flores usualmente com pétalas, lobos do cálice com ápice arredondado e a única encontrada no Brasil.

\section{Dodonaea Mill.}

Arbustos ou arvoretas com glândulas resinosas, polígamo-monoicos, polígamo-dioicos, dioicos ou outras variantes. Folhas simples, alternas, curto pecioladas, estreito-elípticas ou oblongo-lanceoladas, margem inteira; nervação eucamptódroma. Tirso simples ou duplo, axilar ou terminal, cincinos pedunculados; brácteas e bractéolas lineares, decíduas. Flores actinomorfas, monoclamídeas; cálice 4-5-mero, dialissépalo, sépalas cuculadas, ovadas, ou oblongas, glabras a pubescentes, decíduas ou presentes no fruto; corola ausente; androceu: com (5)8-10 estames, filetes curtos, anteras basifixas, disco nectarífero intrastaminal nas flores femininas e bissexuadas, ausente nas flores masculinas; gineceu 3(4) locular, ovário 3(4) trígono-subesférico, 3alado, viscoso, 2 óvulos por lóculo, estilete filiforme, estigma 3-fido. Cápsula septífraga, cartácea, suborbicular, núcleo seminífero central rodeado por ala arredondada. Sementes lenticulares, 1 por lóculo (a outra é abortada), arilo castanho-claro. 
O gênero é predominantemente australiano com aproximadamente 68 espécies, das quais 61 são endêmicas da Australia (West 1984, Harrington \& Gadek 2010). Uma espécie Australiana, D. polyandra Merr. \& L.M. Perry, também ocorre na Nova Guiné e outra D. viscosa é pantropical e temperada (West 1984). Na Serra do Cipó ocorre esta última espécie.

Dodonaea foi um gênero facilmente identificado, por possuir folhas simples, flor monoclamídea e disco nectarífero intrastaminal.

5.1. Dodonaea viscosa Jacq., Enum. syst. pl. 19, f. 5. 1760.

Prancha 2, fig. C-D.

Arbusto 2-4m alt.; ramos cilíndricos, estriados, angulares, achatados ou costados, pubérulos ou glabros, glândulas distribuídas por toda a planta. Folhas (1,5)3-10 x 1-1,8 cm, envernizadas, pecíolo $1 \mathrm{~mm}$ compr., estreitoelípticas ou oblongo-lanceoladas, cartáceas, discolores, ápice agudo, acuminado, margem levemente revoluta, base atenuada, glabra, nervura media proeminente. Tirso ca. $5 \mathrm{~cm}$, eixo achatado ou canaliculado, cincinos 1-3-floros; brácteas e bracéolas 0,5-1,5 mm, glandulosas. Flores 3-5 mm, verde-amareladas, sépalas 0,2-0,3 $\times 0,1-1,5 \mathrm{~mm}$, oblongas ou ovadas, ciliadas; flor 3 : estames glandulosos, filete 0,2-0,4 mm, antera glandulosa, pistilódio pubescente; flor + : estaminódios $2 \mathrm{~mm}$, ovário oblongo, glanduloso, estilete $3 \mathrm{~mm}$, estigma com ramos inconspícuos a conspícuos; flor bissexuada: estames 3-4 mm, gineceu 3,5-5,5 mm. Cápsula 1,5 x 1,9cm, 3(-4) alada, castanho-amarelado, orbicular, ápice e base emarginados, alas cartáceas, epicarpo com glândulas sésseis e tricomas pubérulos, endocarpo glabro; sementes lenticulares $3 \times 4 \mathrm{~mm}$, embrião com os cotilédones circinados.

Material examinado: Minas Gerais: Conceição do Mato Dentro, 1977, P.P.H. Laclette s.n., fr. (RB); Curralino, região de Diamantina, 02.Il.2004, P.L. Viana et al. 1695, fr. (BHCB). 
Material adicional examinado: São Paulo: Jundiai, 07.III.1981, H.F. Leitão Filho et al. 13107, fr. (UEC); Embu, 01.Ill.1995, Franco 1430, fl. ô (SPF, SPSF);

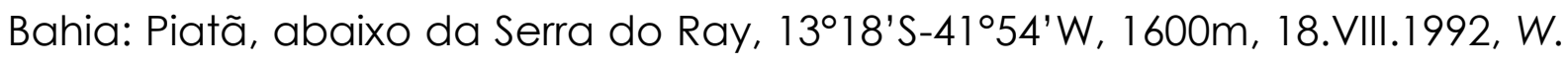
Ganev 907, fl. (SPF, HUEFS, CTES); Morro do Chapéu, cachoeira do Rio Ferro Doido, 1 1³7' 42"S-4100'03"W, 05.III.1997, R. Harley et al 604 1, fl. o (SPF, ALCB).

Ocorre na Austrália, Polinésia, África, Ásia e nas Américas, desde o sul dos Estados Unidos até a região central da Argentina. No Brasil é encontrado nos estados de Rondônia, Maranhão, Ceará, Rio Grande do Norte, Paraíba, Pernambuco, Bahia, Minas Gerais, Espírito Santo, Rio de Janeiro, São Paulo, Paraná, Santa Catarina e Rio Grande do Sul (Somner et al. 2009, 2010). De acordo com Harrington \& Gadek (2009), Dodonaea viscosa tem uma distribuição igual de algumas das maiores dispersões transoceânicas do mundo. É encontrada nos 6 continentes, possuindo uma ampla variedade de tolerâncias climáticas e ecológicas. Na Serra do Cipó foi encontrada em área de mata ciliar; coletada com fruto em março.

West (1984) em seu trabalho de revisão sobre o gênero Dodonaea na Austrália, realizou predições de filogenia baseadas em supostas tendências evolutivas na morfologia, principalmente na cápsula, semente, arquitetura da inflorescência, sistema reprodutivo e foliar e Dodonaea viscosa foi considerada como tendo a maior proporção de caracteres primitivos para o gênero.

\section{Magonia A.St.-Hil}

Árvores monoicas, caule com córtex liso; ramos levemente escamosos, castanho-claros, estriados, lenticelados, glabros ou pubérulos, tricomas eretos ou curvos, densos, esbranquiçados. Folhas paripinadas, alternas, decíduas; folíolos sésseis ou subsésseis, subcoriáceos, discolores, margem inteira; nervação eucamptódroma; domácias ausentes. Tirso simples, cincinos 3-4-floros, longo pedunculados; brácteas e bractéolas triangular- 
subuladas, pubescentes, decíduas. Flores zigomorfas, vistosas; cálice 5-mero, sépalas soldadas na base, estreita-oblongas, ligeiramente desiguais; corola 5-mera, pétalas estreito oblonga, margem revoluta na metade basal, apêndice basal petaloide ausente; disco nectarífero completo, desigual, uma porção simples e a outra dupla, glabro; androceu: estames (7) 8 (9), glabros, filetes cilíndricos, pistilódio curto; gineceu 3-carpelar; ovário ovoide, levemente trilobado; 6-8 óvulos por carpelo, estilete curvo, filiforme, estigma capitado. Cápsula loculicida, plurisseminada, trígono-globosa ou subesférica, pericarpo lenhoso, glabro; sementes achatadas, aladas, largo elípticas ou subtrapezoides, emarginadas.

Gênero monoespecífico, sul-americano, distribuído no Brasil, Bolívia e Paraguai, característico do cerrado (Somner et al. 2009; Joly 1980). Nos estados brasileiros ocorre nos cerrados de Rondônia, Maranhão, Piauí, Ceará, Bahia, Minas Gerais, São Paulo, Goiás, Distrito Federal, Mato Grosso do Norte e do Sul (Joly 1980, Somner et al. 2010).

6.1. Magonia pubescens A. St.-Hil., Hist. Pl. Remarq. Bresil. 1: 239. 1824.

Nome vulgar: Tigui, sabão de soldado

Prancha 2, fig. E-G.

Árvores 4-12m. alt., ramos com lenticelas lineares. Folhas: pecíolo 1,5-6 $\mathrm{cm}$ compr., cilíndrico, alguns complanados na face adaxial; raque subcilindrica, complanada em direção ao ápice, pubescentes ou glabriúsculos, folíolos 3-6 pares, (1,5)2,4-11,5 × (0,7) 1-5,8 cm, alternos, opostos ou subopostos, elípticos, obovados, oblanceolados, estreito-oblongos ou estreito-obovais, ápice emarginado ou arredondado, mucronulado, base obtusa, arredondada ou cuneada; face adaxial com nervura média pubescente, margem pubérula, face abaxial pubescente, nervuras pilosas, nervação mais clara que o limbo e proeminente. Tirso ca. $30 \mathrm{~cm}$, brácteas 3$5 \mathrm{~mm}$ compr. e bractéolas 1-2 $\mathrm{mm}$ compr. Flores $1 \mathrm{~cm}$; sépalas $4 \times 2 \mathrm{~mm}$, pubescente, glandular, margem ciliada; pétalas $1-1,3 \times 0,3 \mathrm{~cm}$, face abaxial 
verde, pubescente, face adaxial púrpura, pubérula no ápice e margem; disco nectarífero em parte pubérulo; flor $\delta^{t}$ : estames $8 \mathrm{~mm}$ compr., verdes, anteras esbranquiçadas, pistilódio pubescente; flor $q$ : estaminódios $4 \mathrm{~mm}$ compr., ovário pubescente, estilete com poucos tricomas dispersos. Cápsula 7,9-9,5 × 8,6-11,2 cm, castanha-clara a castanha, epicarpo áspero, endocarpo glabro; sementes $8 \times 5 \mathrm{~cm}$ diâm.

Material examinado: Minas Gerais, Santana do Riacho: 8 km do início da estrada para Santana do Riacho, saindo da estrada Lagoa SantaConceição do Mato Dentro, 19¹6'40.9"S-4338'34.1"W, 728m, 23.IX.2006, M.F. Calió et al. 134, fl. + , ô (SPF, SPFR); 1,5 km do início da estrada de terra para Santana do Riacho com início na ponte de ferro para a Usina Dr. Pacífico Mascarenhas, 02.IX.2008, K.F. Silva \& R.F. Oliani 99, fr. (SPF, SPFR); Distrito de São José da Cachoeira (Inhame). Santana de Pirapama. Estrada de terra que sai de frente a um mercadinho sentido rio Cipó, 1857'53.1"S43046'58.1 "W, 673m, 06.III.2009, K.F. Silva et al. 115, fr. jov. (SPFR, K); Estrada de

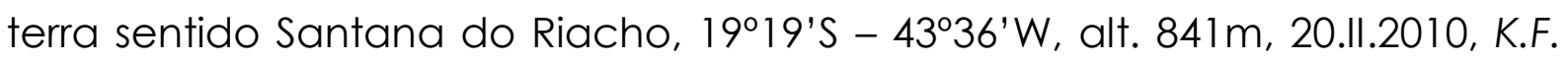
Silva \& T.P. Martins 150, fr. (SPFR); idem, K.F. Silva \& T.P. Martins 155 (SPFR);

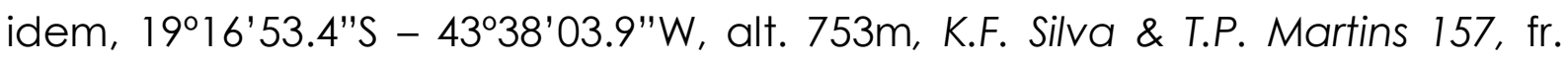
(SPFR); idem, K.F. Silva \& T.P. Martins 159, fr. (SPFR); idem, K.F. Silva \& T.P. Martins 160 (SPFR).

Magonia pubescens foi facilmente identificada por suas cápsulas grandes, globosas e suas sementes aladas. A espécie também possui como característica muito importante e única presente na família Sapindaceae, o pólen em tétrades tetraédricas (Radlkofer 1931-1934, Muller \& Leenhouts 1976). Segundo Joly (1979), a espécie é decídua, ocorrendo perda das folhas de abril a junho; na Serra do Cipó observou-se a árvore sem suas folhas no mês de agosto e setembro. Ainda de acordo com Joly (1979), a floração ocorre de junho a setembro, e a renovação da folhagem vai de agosto a dezembro; a abertura dos frutos ocorre de agosto a outubro, estando correlacionada com o início da estação chuvosa. Na Serra do Cipó foi encontrada em áreas de cerrado e carrasco; coletada com flor em setembro e frutos em fevereiro, março e setembro. 
7. Matayba Aubl.

Árvores ou arbustos monoicos; ramos cilíndricos, estriados, castanhoescuros, glabros ou pubescentes, lenticelados. Folhas paripinadas, alternas; folíolos alternos ou subopostos, peciolulados ou raro sésseis, margem geralmente inteira, venação eucamptódroma ou broquidódroma, secundárias arqueadas, curvado-ascendentes ou retilíneas, terciárias reticuladas; domácias presentes ou ausentes. Tirso simples ou duplos, terminal ou axilar, cincinos curto-pedunculados, brácteas e bractéolas persistentes. Flores actinomorfas, pediceladas; cálice 4-5-mero, gamossépalo, sépalas concrescidas na base, lóbulos subtriangulares a ovados, glabras a pubescentes, margem ciliada; corola 5-mera, pétalas ungüiculadas, obovais; apêndice petaloide bipartido, viloso; disco nectarífero completo, anelar, 5lobado; androceu: (7-)8(-9) estames, filetes cilíndricos, anteras glabras ou pubescentes; gineceu 2-3 carpelar, 1 óvulo por carpelo, ovário ovoide, globoso, pubescente-tomentoso, estigma (2-)3-lobado. Fruto cápsula loculicida, curto estipitadas; sementes elipsoides, ovoides ou obovoides, arilo carnoso.

Gênero americano com aproximadamente 56 espécies, representado desde o México até o nordeste da Argentina (Ferrucci et al. 2009b). Para o Brasil são referidas 31 espécies, sendo 17 endêmicas, presentes em diversas formações vegetacionais (Somner et al. 2010). Na Serra do Cipó ocorrem cinco espécies. Todas as espécies de Matayba encontradas na Serra do Cipó encontram-se na Sect. Matayba que inclui espécies com os folíolos frequentemente com domácias, flores com disco nectarífero glabro, pétalas com apêndice petalóide bipartido, cápsula curtamente estipitada, geralmente trígono-subglobosa e endocarpo viloso. 


\section{Chave para as espécies de Matayba}

1.Folíolos com nervuras secundárias retilíneas.

2.Folíolos assimétricos, face adaxial com venação inconspícua 7.2 . M. intermedia

2'.Folíolos simétricos, face adaxial com venação conspícua

3.Folíolos 3-5 pares, oblongos ou obovados. 7.3. M. juglandifolia

3'.Folíolos mais de 5 pares de folíolos, elípticos ou lanceolados

7.5. M. stenodictya

1 '.Folíolos com nervuras secundárias arqueado-ascendentes

4.Folíolos conduplicados e recurvados, com face abaxial glabra ou com tricomas adpressos dispersos............................7.1. M. guianensis 4'.Folíolos não conduplicados e recurvados, com face abaxial velutina ou denso pubescente. 7.4. M. mollis

7.1. Matayba guianensis Aubl., Hist. pl. Guiane 1: 331, †. 128. 1775.

Prancha 2, fig. $\mathrm{H}$.

Arbustos ou árvores 1-6m alt.; ramos subcilíndricos, levemente sulcados, glabros ou pubescentes, lenticelas lineares ou verrucosas. Folhas: pecíolo 0,7$8 \mathrm{~cm}$ compr. e raque cilíndricos ou subcilíndricos, estriados, face adaxial levemente complanados, canaliculados, pubescentes, peciólulo 1-5 mm compr.; folíolos (2)4-5(8) pares, 3,6-12,5 (15) x 1,2-3,2(4,5) cm, elípticos, oblongos ou estreito-ovados, cartáceos, discolores, ápice obtuso, retuso, margem inteira, revoluta, conduplicado, recurvado, base obtusa, oblíqua, face adaxial glabra ou com tricomas curtos, adpressos, nervura média impressa, pubescente, face abaxial glabra ou pilosa com tricomas adpressos 
dispersos, venação eucamptódroma, nervuras secundárias arqueadoascendentes, domácias urceoladas ou ausentes. Tirso duplo, axilar, subterminal, $10(25) \mathrm{cm}$ compr., cincinos 3-5-floros, brácteas e bractéolas 1-2 $\mathrm{mm}$ compr., triangulares. Flores 3-4 mm, amarelo-esbranquiçadas, cálice 45 mero, sépalas $1 \times 1 \mathrm{~mm}$, lóbulos ovoides, coriáceos, glabras ou pubescentes; corola 5-mera, pétalas $2 \times 1 \mathrm{~mm}$, obovoides, ápice emarginado, apêndice viloso, margem ciliada; disco nectarífero glabro; flor 3: estames 3-4 mm, filetes vilosos até $2 / 3$, anteras glabras, pistilódio ovoide, tomentoso; flor p: estaminódios $1 \mathrm{~mm}$, ovário globoso, pubescente, estigma 3-lobado, lobos conspícuos ou inconspícuos. Fruto 0,5-1,4 $40,4-1,2 \mathrm{~cm}$, trígono-globoso, estípite 0-1,5 mm, epicarpo verrucoso, coriáceo, tricomas adpressos, pubescente, endocarpo viloso; sementes $1 \times 0,7 \mathrm{~cm}$, elipsoides, arilo cobrindo até o meio.

Material examinado: Minas Gerais, Santana do Riacho: km ao longo da rodovia Belo Horizonte-Conceição do Mato Dentro: Mãe d' $\mathrm{H}_{2} \mathrm{O}$, 08.X.1981, J.R. Pirani et al. CFSC 7596, fl. ồ fr. (CTES, K, SPF); idem, atalho para o Morro do Calcáreo, 07.X.1981, M.L. Kawasaki et al. CFSC 7568, fl. ㄱ. 우 (CTES, SPF); idem, Parque Nacional da Serra do Cipó, região das Canelas de Ema Gigantes, 1400m, 13.I.1992, M. Pereira \& M. Lucca 1072, fl. ㅎ. 우 (BHCB); afloramento de calcáreo próximo à Cardeal Mota, 07.IX.1987, D.C. Zappi et al. CFSC 10448, fl. $\hat{o}$, o (CTES, K, SP, SPF); Serra do Cipó, Cardeal Mota, trilha

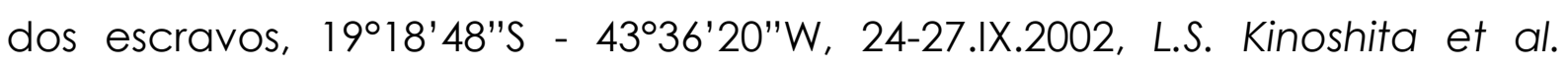
02/145, fr. (SPFR, UEC); km 104 da rodovia MG-010 (Lagoa Santa-Conceição do Mato Dentro), trilha dos escravos, 19018'52.0"S-43036'24.3"W, 877m, 30.VIII.2008, K.F. Silva \& R.F. Oliani 87, fl. $\hat{\jmath}$, $q$, fr. jov. (CTES, SPF, SPFR); Conceição do Mato dentro, estrada de terra sentido Tabuleiro, 1901 '35.1"S4331'32.6"W, 774m, 16.VIII.2009, K.F. Silva \& R.F. Oliani 222 (SPFR).

Ocorre no Suriname, Guiana Francesa, Tobago, Peru, Bolívia e no Brasil (Ferrucci et al. 2009b), é encontrada nos estados do Amapá, Pará, Amazonas, Tocantins, Rondônia, Maranhão, Ceará, Paraíba, Bahia, Mato Grosso, Goiás, Distrito Federal, Mato Grosso do Sul, Minas Gerais, Espírito Santo, São Paulo, Rio de Janeiro, Paraná, Santa Catarina, Rio Grande do Sul 
(Somner et al. 2010). Presente na maioria das formações vegetacionais brasileiras, porém prevalecendo nos cerrados e em matas ciliares (Coelho 2008). Na Serra do Cipó foi encontrada no cerrado e em afloramento de calcáreo; coletada com flor e fruto em agosto, setembro e outubro.

Matayba guianensis foi identificada principalmente pelas jugas mais espassadas, indumento curto e adpresso, folíolos recurvados e conduplicados, nervação impressa na face adaxial e nervuras secundárias arqueado-ascendentes, e segundo Coelho (2008), estes caracteres são fatores importantes e quase exclusivos para esta espécie.

7.2. Matayba intermedia Radlk., in Mart., Fl. Bras. 13(3): 619. 1900.

Prancha 2, fig. J.

Árvore 8-11m alt., ramos cilíndricos, tricomas adpressos, brancoamarelados a amarelados, lenticelas verrucosas. Folhas: pecíolo 1,7-7,5 cm compr. e raque subcilíndricos, estriados, face adaxial complanados, glabros, peciólulo 3-5 mm compr.; folíolos (3)4-5(8) pares, 3,5-12,5 x 1,5-3,2, brilhantes, elípticos, elíptico-lanceolados, assimétricos, cartáceos, discolores, ápice agudo, acuminado, levemente cuspidado, margem inteira, ondulada, subrevoluta, base cuneada ou oblíqua, face adaxial glabra, nervura média impressa, face abaxial glabra; venação broquidódoroma, nervuras secundárias retilíneas ascendentes; domácias ausentes. Tirso simples, axilar ou subterminal, 8-20 cm compr., cincinos 1-3-floros, brácteas e bractéolas 1-2 $\mathrm{mm}$ compr., triangulares, subuladas. Flores 3-4 mm, brancas, cálice 5-mero, sépalas $1 \times 1 \mathrm{~mm}$, lóbulos ovados, coriáceos, pubescentes; corola 5-mera, pétalas $2 \times 1 \mathrm{~mm}$, obovais, ápice obtuso, apêndice viloso, margem ciliada; disco nectarífero glabro; flor $\hat{o}^{*}$ : estames $3 \mathrm{~mm}$, filetes vilosos na base, anteras glabras, pistilódio ovoide, tomentoso; flor o: estaminódios $1 \mathrm{~mm}$, ovário obovoide, pubescente, estigma 3-lobado, lobos conspícuos. Fruto trígonoobovoide ou subgloboso, 1,2 × 1,3 cm, castanho-avermelhado, estípite curto 
ou ausente, epicarpo seríceo-tomentoso, endocarpo viloso; sementes elipsoides, $0,8 \times 0,6 \mathrm{~cm}$, arilo cobrindo até $2 / 3$ de semente.

Material examinado: Minas Gerais, Itambé do Mato Dentro, Distrito de Santana do Rio Preto (Cabeça de Boi), APA do PARNA Serra do Cipó, 19²5'54.7"S-4325'58.3"W, 13.III.2008, M.F. Santos \& H. Serafim 247, fr. (SPF, SPFR).

Material adicional examinado: Brasil: São Paulo, Alto da Serra, Estação Biológica, 12.XII.1928, Celestino Lemos s.n., fl. ô (SPF); idem, Parque Santos Dias, 2339' 47"S-4646'21 "W, 10.XI.1993, R.J.F. Garcia 435, fl. + (PMSP, SPF); Rio de Janeiro, Tijuca, 18.11.1883, Schwacke 4829, fl. (M, sintipo); Rio de Janeiro, s.d., Glaziou 8607, fr. (B, sintipo, foto F, negativo 5698).

Espécie endêmica do Brasil, ocorre no Rio de Janeiro, São Paulo, em ambos estados em restinga e floresta ombrófila densa, enquanto no Paraná, Santa Catarina e Rio Grande do Sul ocorre nas florestas ombrófilas densas nas encostas de morros e menos comum em altitudes mais baixas, em margens de rios ou ainda em planícies alagadiças (Somner et al. 2009, 2010, Coelho 2008). Na Serra do Cipó esta espécie possui apenas duas coletas e está aparentemente isolada na porção leste, em Mata Estacional Semidecídua, sendo seu primeiro registro de ocorrência para o estado de Minas Gerais; coletada com fruto em março.

Matayba intermedia foi identificada principalmente pela pelos folíolos na face adaxial com nervura média impressa e secundárias retilíneas. $M$. intermedia é morfologicamente afim a $M$. discolor o que as diferem são os caracteres supracitados para $M$. intermedia enquanto $M$. discolor possui folíolos com nervura média fracamente proeminente na face adaxial. Também por não apresentarem a mesma distribuição geográfica. 
7.3. Matayba juglandifolia (Cambess.) Radlk., Sitzungsber. Math.-Phys. Cl. Konigl. Bayer. Akad. Wiss. Munchen 9: 635. 1879.

Sapindus juglandifolius Cambess., in St. Hil. Fl. Bras. 1: 391. 1825.

Prancha 2, fig. I.

Árvore 4-8m alt.; ramos jovens com pelos adpressos, amareloferrugíneos, lenticelas lineares ou verrucosas. Folhas: pecíolo $2-4 \mathrm{~cm}$ compr. e raque subcilíndricos, estriados, face adaxial complanados, canaliculados, pubérulos, peciólulo 3-5 mm compr.; folíolos 3-5 pares, $5-12,5 \times 1,7-4,5 \mathrm{~cm}$, alternos, oblongos ou obovados, cartáceos ou subcoriáceos, ápice retuso, arredondado, raro agudo, margem inteira, base atenuada, aguda, oblíqua, face adaxial glabra, nervura média plana, glabra ou pubescente, face abaxial glabra ou com tricomas curtos, adpressos, venação broquidódroma, nervuras secundárias retilíneas, domácias urceoladas ou ausentes. Tirso duplo, axilar, terminal, $15-30 \mathrm{~cm}$ compr., cincinos 3-floros, pubescentes, tricomas curtos, adpressos; brácteas 1-2 mm compr. e bractéolas $1 \mathrm{~mm}$ compr., ovoide-triangulares. Flores 5-7 mm, creme-esverdeadas, cálice 5mero, sépalas $1 \times 1 \mathrm{~mm}$, lóbulos ovados, ápice agudo, coriáceas, pubérulas ou pubescentes; corola 5-mera, pétalas 1,5 × 1,5 mm, obovais, espatuladas, flabeliformes, ápice irregular, margem ciliada; disco nectarífero glabro; flor $\widehat{s}$ : estames 3-4 mm, filetes pubescente-vilosos até $2 / 3$, anteras glabras, pistilódio ovoide, tomentoso; flor o: estaminódios $1,5 \mathrm{~mm}$, ovário ovoide, tomentoso, estigma com lobos inconspícuos. Fruto jovem ca. 1 × 0,8 cm, trígono-globoso, castanho, estípite 1-2 mm, epicarpo verrucoso, pubescente, indumento amarelado, endocarpo viloso-tomentoso; sementes $3 \times 1 \mathrm{~mm}$, oblongas.

Material examinado: Minas Gerais, Santana do Riacho, km 119 (atual 117) ao longo da rodovia Belo Horizonte-Conceição do Mato Dentro, perto da Fazenda Palácio, 4.IX.1980, I.Cordeiro CFSC 6515 \& J.R. Pirani, fl. ô, + (SP, SPFR). 
Material adicional examinado: Minas Gerais, Caldas, Pocinhos do Rio Verde, Serra da Pedra Branca, 2157'41.6"S-46²2'10.2"W, 21.X.2008, M.G. Rezende 212 \& R.C.L. Elias, fr. jov. (CESJ, SPFR).

Espécie endêmica do Brasil, ocorre nos estados da Bahia, Minas Gerais, Rio de Janeiro, São Paulo, Paraná e Santa Catarina (Ferrucci et al. 2010), sempre em florestas tropicais como as florestas estacionais semidecíduas, matas ciliares e nas bordas destas formações, aparecendo também na transição entre as florestas e o cerrado e em uma frequência muito menor apenas nos cerrados. Na Serra do Cipó esta espécie parece ser rara, com apenas uma coleta em mata ciliar; coletada com flor em setembro.

Matayba juglandifolia foi identificada principalmente pela nervura média plana e nervuras secundárias retilíneas; segundo Radlkofer (1933) é muito semelhante a M. grandis e M. pallens, o que a difere são os folíolos oblongos, as nervuras secundárias e a distribuição geográfica supracitadas, enquanto em M. grandis os folíolos são elíptico-lanceoladas, as nervuras secundárias arqueadas e segundo Somner et al. (2010) encontrada nos estados de Minas Gerais e Rio de Janeiro, e em M. pallens os folíolos são lanceolados, as nervura secundárias arqueadas ascendentes e de acordo com Somner et al. (2010) é restrita ao estado de São Paulo.

7.4. Matayba mollis Radlk., Sitzungsber. Math.-Phys. Cl. Königl. Bayer. Akad. Wiss. München 9: 634. 1879.

Nome vulgar: mataiba

Prancha 2, fig. K.

Árvores ou arbustos 2-10m alt.; ramos cilíndricos, sulcados, velutinos, lenticelas lineares. Folhas: pecíolo 1,5-3,9 cm compr. e raque cilíndricos, estriados, face adaxial cilíndricos ou levemente complanados, canaliculados, denso pubescentes ou velutinos, peciólulo 0-1 mm compr.; folíolos (3) 4-6 pares, (1,3)2,2-10,5(14,3) x 1,4-4,4 cm, alternos ou subopostos, ovados, lanceolados ou elíptico-lanceolados, cartáceos, ápice obtuso ou 
retuso, margem inteira, subrevoluta, recurvado, conduplicado, base obtusa, oblíqua, face adaxial pubérula, pubescente ou pilosa, nervura média pouco proeminente, pubescente, face abaxial velutina ou denso pubescente, venação eucamptódroma, nervuras secundárias arqueado-ascendentes, mais claras que o limbo, domácias urceoladas. Tirso simples ou duplo, axilar, subterminal, 15-(30) cm compr., cincinos 3-5-floros, pubescentes, brácteas e bractéolas 1-3 mm compr., triangular-lanceoladas, pubescentes. Flores 3-4 $\mathrm{mm}$, brancas, cremes, amareladas ou verdes, cálice 5-mero, sépalas 1,5 mm, lóbulos ovados, ápice obtuso, coriáceas, pubescentes, margem ciliada; corola 4-5-mera, pétalas $2 \mathrm{~mm}$, obovais, ápice emarginado, glabras, pubérulas ou vilosas, margem ciliada; disco nectarífero glabro; flor 3 : estames 2-4 mm, filetes cilíndricos, pubescentes no $2 / 3$, anteras glabras, pistilódio ovoide, velutino; flor p: estaminódios 1-2 mm, ovário obovoide, tomentoso, estigma 2-3-lobado, lobos conspícuos, livres. Fruto 1,2-1,5 × 1,5-2 cm, trígonoobovoide, vermelho, estípite 0-1 mm, epicarpo verrucoso, coriáceo, pubescente, endocarpo velutino; sementes $0,9-1,3 \times 0,7-1 \mathrm{~cm}$, oblongas, negras, arilo branco, cobrindo até o meio ou toda a semente.

Material examinado: Minas Gerais: Jaboticatubas, PARNA Serra do Cipó: 19²0'S-4337', 600-700m, 21.XI.2000, L.S. Kinoshita \& A.M.G.A. Tozzi 00/360, fl. + (UEC); idem, proximidades da sede do IBAMA, 21.XI.2000, K.Yamamoto \& M.F. Freitas 00/76, fl. ô., o e fr. (UEC), 19²0'56.6"S-433'08.2"W, 817m, 20.II.2010, K.F Silva \& T.P. Martins 161, fr. (CTES, RB, SPF, SPFR); idem, 19020'56.6"S- 43037'08.2"W, 817m, 29.V.2010, K.F Silva et al. 208, fl. ô, + (CTES, RB, SPF, SPFR); Santana do Riacho: $19^{\circ} 21^{\prime}$ 'S-43⒊' W, 790m, 06.II.1981, F.C.F. da Silva 98, fl. \& (RB), idem, $19^{\circ} 21^{\prime}$ 'S-433' W, 790m, 06.ll.1981, G.C.P. Pinto 360, fl. ㅇ, fr. (RB); idem, 19²1'S-4338', 790m, 06.XI.1981, O.A. Salgado 189, frutificando (RB), idem, UCAT, 14.IV.1985, P.M. Andrade \& M.A. Lopes $s / n^{\circ}$, frutificando (BHCB); idem, ao longo da rodovia Belo Horizonte-Conceição do Mato Dentro, idem, km 114 (atual 108), 19.XII.1979, J.R. Pirani \& M.C. Amaral CFSC 5875, fl. (SP, SPFR); idem, km 114 (atual 108), 19.XII.1979, J.R. Pirani \& M.C. Amaral CFSC 5878, fl. ㅇ, ô (SP, SPFR), idem, km 114 (atual 108), 19.XII.1979, J.R. Pirani \& M.C. Amaral CFSC 5864, frutificando (SP, SPFR); idem, 
km 114 (atual 108), estrada da Usina, 20.XII.1979, J.R. Pirani et al. CFSC 5925, frutificando (SP, SPFR); idem, 20.XII.1979, J. Semir CFSC 5938, fr. (SP, SPFR); idem, km 106, Córrego Chapéu de Sol, 09.XI.1980, J.R. Pirani CFSC 6752, fl. §ิ (SP, SPFR).

Espécie endêmica do Brasil, ocorre apenas em Minas Gerais principalmente nos cerrados (Somner et al. 2010), e campos rupestres com afloramentos rochosos, além de matas de encosta, ciliares e semidecíduas, em altitudes que variam entre 672-1350m de alt. (Coelho 2008). Na Serra do Cipó esta espécie foi encontrada no cerrado, cerradão, mata, mata de galeria e mata ciliar; coletada com flores e frutos em fevereiro, novembro e dezembro.

Matayba mollis foi identificada principalmente pelos folíolos velutinos ou denso pubescentes, fruto com epicarpo verrucoso e arilo cobrindo até o meio ou toda a semente. É morfologicamente afim a M. punctata diferindo dessa pelos folíolos oblongos, pontos translúcidos ausentes, domácias urceoladas e díficeis de serem visualizadas por causa da densa pubescência do folíolo em M. mollis, enquanto em M. punctata os folíolos são ovais a suborbiculares, pontos translúcidos são presentes e as domácias foveoladas são mais visíveis (Coelho 2008); M. punctata embora presente em Minas Gerais não foi encontrada na Serra do Cipó.

7.5. Matayba stenodictya Radlk., in Martius Fl. Bras. 13(3): 629. 1900.

Prancha 2, fig. L-M.

Árvores, arbustos, 1-6m alt.; ramos cilíndricos, glabros ou com tricomas curtos, adpressos, pubérulos no ápice, amarelo-ferrugíneos, lenticelas lineares ou verrucosas. Folhas: pecíolo 1,4-10 cm compr. e raque cilíndricos, subcilíndricos, estriados, face adaxial levemente complanados, canaliculados, bicanaliculados, tricomas curtos, adpressos, pubérulopubescentes ou glabros, peciólulo 1-4 mm compr.; folíolos 5-7 pares, 4,5-20 x 1,8-5 cm, alternos, subopostos, elípticos ou lanceolados, cartáceos ou coriáceos, ápice agudo, acuminado, obtuso ou ocasionalmente 
emarginado, margem inteira, subrevoluta, recurvados, conduplicados, base oblíqua, pouco atenuada, glabros, face adaxial brilhante, lustrosa, venação broquidódroma, nervura média plana, glabra a pubescente, face abaxial glandulosa, nervura média pilosa, nervuras secundárias retilíneas, domácias ausentes. Inflorescência (não visualizada, retirada de Radlkofer 1934): panículas, axilares, ramificadas, pubérulas, brácteas pequenas, subuladas, $1 \mathrm{~mm}$; cimeira subséssil; pedicelo $2 \mathrm{~mm}$, pubescente. Flores esverdeadas. Cálice 1,5 mm, 5-dentado, sépalas com tricomas adpressos, pubérulos, subcoriáceos. Pétala branca, obovado-cuneada, ápice denticulado, pubérula; apêndice petaloide com escama basal vilosa. Estames $2,5 \mathrm{~mm}$ compr., subulado-filiforme, ápice vilosiúsculo; antera glabra. Ovário ovoide, tomentoso, 1,5 mm compr., estilete cônico, estigma 3-fido. Fruto 0,8-1,2 × 0,8$1,3 \mathrm{~cm}$, globoso, lobos conspícuos ou inconspícuos, estípite $1 \mathrm{~mm}$, epicarpo verrucoso, tricomas curtos e adpressos, endocarpo velutino; sementes 1-(2), 4-5 × $3 \times 4 \mathrm{~mm}$, elipsoides.

Material examinado: Minas Gerais: Serra do Cipó, km 134, 25.X.1961, A.P. Duarte 5691, fr. (RB, ESA, SPFR); Santana do Riacho, ao longo da rodovia Belo Horizonte-Conceição do Mato Dentro, km 126 (atual 115): 19.XII.1979, J.R. Pirani \& M.C. Henrique CFSC 5886 (SP, SPFR); idem, km 132, 29.II.1980, J.R. Pirani CFSC 5959 (SP, SPFR); idem, km 130, 19¹2'55.1"S-4330'32.6"W, 1322m, 29.V.2010, K.F. Silva et al. 190 (CTES, SPFR); idem, $2^{\circ}$ Capão de Mata, 19०12'55.2"S-4330'32.5"W, 1320m, 29.V.2010, K.F. Silva et al. 193 (SPFR); idem, km 119, 19015'20.5"S-43⒊'09.5"W, 1353m, 30.V.2010, K.F. Silva et al. 197 (SPFR); ca. 400m da bifurcação Morro do Pilar-Conceição do Mato Dentro 19¹2'53.8"S-4330'39.0"W, 1349m, 14.VI.2007, K.F. Silva et al. 16 (SPFR).

Material adicional examinado: Brasil, Minas Gerais, Serra de Antonio Pereira, 27.VIII.1892, Schwacke 8746, fr. (B, sintipo, foto F, negativo 5705); Pará, Oriximiná, 10.VII.1970, C.A. Cid 1434 et al., fr., (US: foto); Amazonas, Presidente Figueiredo, $01^{\circ} 35^{\prime}$ S-59 $48^{\prime}$ 'W, 7.VII.1986, W.Thomas 5372 et al. (US: foto); Amazonas, Reserva Florestal Ducke, 25.III.1997, J.E.L.S. Ribeiro \& E. da C. Pereira 1870, fl. (US: foto) ; idem, 05.V.1994, J.E.L.S. Ribeiro 1313 et al., fr. (US: foto) 
É endêmica de Minas Gerais principalmente na Mata Atllântica (Somner et al. 2010). Na Serra do Cipó esta espécie foi encontrada em capão de mata, remanenscente de mata ciliar, mata e entre blocos de quartzito micacio; coletada com frutos em outubro.

Matayba stenodictya foi identificada principalmente pelos folíolos elípticos, ovados, escuros, face adaxial com nervura media plana e fruto globoso com epicarpo verrucoso. É morfologicamente afim a $M$. elaeagnoides diferindo dessa de acordo com Radlkofer (1933) pelos folíolos elípticos, margem subrevoluta, escura, nervuras secundárias retilíneas, laterais numerosas, raque complanada na face adaxial ou bicanaliculada em $\mathrm{M}$. stenodictya enquanto em $M$. elaeagnoides os folíolos são oblongos, lanceolados ou obovado-cuneados, margem revoluta, nervuras secundárias arqueado-ascendentes e domácias presentes.

O último registro de coleta de Matayba stenodictya são os materiais sintipos de Magalhes-Gomes 488, Ouro Preto e Schwacke 8746, Antonio Pereira, citados por Radlkofer (1900). Coelho (2008) coloca M. stenodictya como espécie de posicionamento incerto porque segundo o autor não foi encontrado material suficiente para correta identificação. Dessa maneira nesse trabalho a espécie foi praticamente redescoberta, e a descrição do fruto é inédita para ciência já que no trabalho de Radlkofer $(1900,1934)$ encontra-se apenas descrição das partes vegetativas e da flor feminina. 


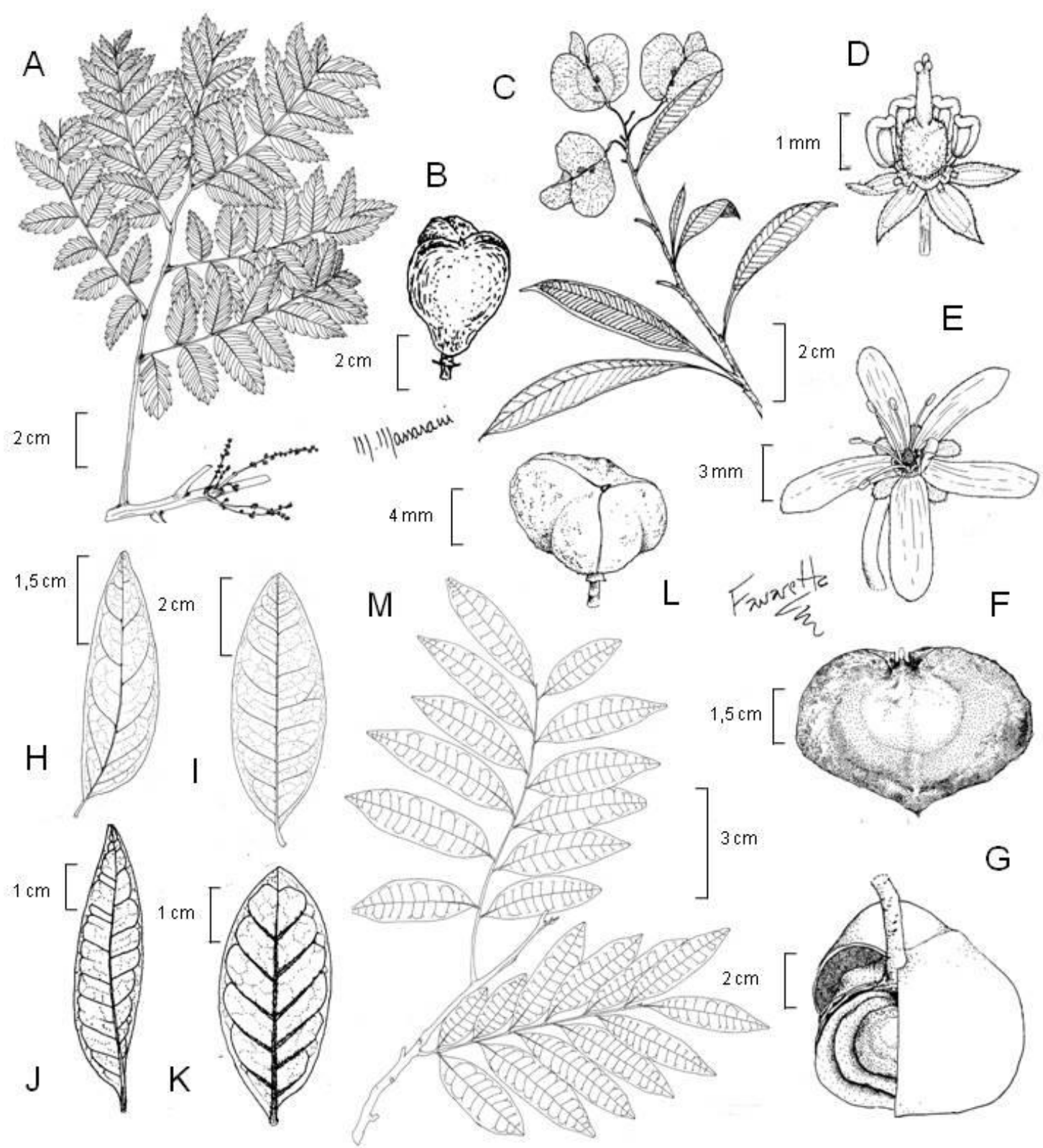

Prancha 2. A-B. Dilodendron bipinnatum, A. ramo florifero; B. fruto. C-D. Dodonaea viscosa. C. ramo frutífero; D. flor mostrando o disco nectarífero intraestaminal, as pétalas e 4 estames foram retirados. E-G. Magonia pubescens, E. flor mostrando o disco nectarifero completo, desigual, uma porção simples e a outra dupla; F. semente; G. fruto. H. Matayba guianensis, folíolo; I. Matayba juglandifolia, folíolo; J. Matayba intermedia, folíolo; K. Matayba molis, folíolo; L-M. Matayba stenodictya, L. fruto; M. ramo. (A-B, Souza et al. 183; C-D, Ganev 907; E-G, Calió 134 (fl.), Silva \& Oliani 99 (fr.); H. Pirani et al. CFSC 7596, I, Silva et al. 184; J, Cordeiro \& Pirani CFSC 6515; K, Silva et al. 208, L-M, Silva et al. 197.) Ilustraçôes: A-B, M: Massarani; C-K: Favaretto. 


\section{Paullinia L.}

Trepadeiras lenhosas, monoicas, látex presente ou ausente, gavinhas na base da raque da inflorescência, caule simples ou composto, glabros ou com tricomas, adultos lenticelados. Folhas imparipinadas, alternas, pecioladas; estípulas persistentes ou decíduas; folíolos peciolulados ou sésseis, margem inteira, serreada ou denteada, geralmente com glândula no ápice ou na extremidade das nervuras secundárias, venação broquidódroma ou craspedódroma, terciárias reticuladas ou percorrentes; domácias presentes. Tirso racemiforme ou espiciforme, cincinos pedunculados, brácteas e bractéolas subulada-triangulares ou lineares, com indumento. Flores zigomorfas, pediceladas, cálice 4-5-mero, dialissépalo, sépalas cuculadas; corola 4-mera, pétalas ungüiculadas, espatuladas, geralmente glandulosas, apêndice petaloide inflexo ou 2 linguetas, porção basal vilosa, ápice com crista inteira ou de outros tipos, vilosa, lobos nectaríferos 4, os posteriores maiores, os anteriores menores, glabros; androceu: estames desiguais, filetes achatados, glabros ou com indumento, anteras dorsifixas, glabras, pistilódio glabro ou pubescente; gineceu: ovário 3carpelar, 3-locular, 1 óvulo por lóculo, estilete filiforme, estigma 3-fido. Cápsula septífraga, 3-valvar, alada ou costada, estipitada, pericarpo subcarnoso, glabra ou com indumento. Semente com arilo branco.

Gênero com aproximadamente 200 espécies, distribuídas desde o México até o nordeste da Argentina (Somner 2001, 2009, Ferrucci 1991), a única exceção é P. pinnata L. que ocorre na África (Radlkofer 1931-1934, Somner 2001). No Brasil ocorrem 97 espécies, sendo 37 endêmicas (Somner et al. 2010). Na Amazônia ocorre o maior número de espécies, sendo considerada o centro de diversidade genética do gênero (Somner 2001). As espécies de Paullinia geralmente ocupam florestas úmidas e perenifólias, talvez associadas ao padrão de dispersão zoocórica (Somner 2001). Na Serra do Cipó ocorrem cinco espécies. 
O nome Paullinia foi dedicado por Linnaeus a Simon Paulli (1603-1680), nascido em Rostock, professor em Kopnhagen, onde escreveu uma Flora da Dinamarca e onde faleceu.

\section{Chave para as espécies de Paullinia}

1.Caule composto, folíolos com nervuras terciárias percorrentes. 8.4. P. spicata

1'.Caule simples, folíolos com nervuras terciárias reticuladas.

2.Folhas 5-foliolada, folíolos basais com foliólulos laterais reduzidos 2-6 $\mathrm{mm}$

8.3. P. racemosa

2'.Folhas 3-5 jugas, folíolos basais menores não reduzidos.

3.Folíolos com margem inteira, venação broquidódroma; frutos não alados. 8.1. P. carpopoda 3'.Folíolos com margem denteado-serreada, venação craspedódroma; frutos alados.

4.Látex ausente, caule cilíndrico, castanho-avermelhado, glabro ou pubérulo; estípula ovada, $1 \mathrm{~mm}$ compr., domácias foveoladas e barbadas...............................................8.5. P. trigonia 4'.Lactescente, caule 5-costados, levemente sulcado, castanho, hirsuto ou pubescente; estípula foliácea ou cuneiforme, 0,5-2 cm compr., domácias barbadas, raro em bolsas..........8.2. P. meliifolia

8.1. Paullinia carpopoda Cambess., Fl. Bras. Merid. (quarto ed.) 1:376. 1828.

Nome vulgar: Timbó

Prancha 3, fig. A-B. 
Trepadeiras lactescentes, caule simples, ramos levemente triangulares, pilosos, tomentosos ou pubérulo-pubescentes, lenticelas verrucosas. Folhas 34 jugas, folíolos basais 3-foliolulados, pecíolo 2-5,7(8) cm compr., estriado, canaliculado ou bicanaliculado, raro marginado ou alado, face adaxial levemente complanado, raque alada; estípula subulada, $1 \mathrm{~mm}$ compr.; folíolos 1,1-13 x 0,6-3 cm, elípticos ou lanceolados, discolores, cartáceos ou subcoriáceos, ápice acuminado, cuspidado, mucronulado, com glândula, margem inteira, subrevoluta, base aguda, cuneada a atenuada, face adaxial glabra, pilosa nas nervuras, face abaxial com tricomas curtos, retos ou adpressos ou pubescente, venação broquidódroma, terciárias reticuladas; domácias foveoladas ou barbadas. Tirso racemiforme, $10-22 \mathrm{~cm}$ compr., cincinos (3)4-5(6)floros, brácteas e bractéolas 1-2 mm, subuladatriangulares, velutinas. Flores 4-6 mm, branco-amareladas, sépalas 4, 1-4 mm, ovadas, obovadas, cartáceas a coriáceas, velutinas; pétalas 2-5 mm, apêndice petaloide com crista inteira ou emarginada, lobos nectaríferos orbiculares; flor $\mathrm{o}^{\mathrm{i}}$ : estames $2-3 \mathrm{~mm}$, filetes tomentoso-velutinos, anteras glabras, pistilódio glabro; flor o: ovário elipsoide, glabro, estilete com ramos glandulosos. Cápsula 1-2 × 1-1,5 cm, avermelhada, globosa, 6-costada, estípite 3-5 mm compr., epicarpo e endocarpo glabro. Sementes 1-1,4 × 0,6$1,3 \mathrm{~cm}$, elipsoides, arilo cobrindo quase toda a semente.

Material examinado: Minas Gerais: Parque Nacional da Serra do Cipó, Serra do Cipó, km 175, 28.IV.1978, H.C. de Lima et al. 496, fr. jov. (SPFR, RB); Jaboticatubas, ao longo da rodovia Lagoa Santa-Conceição do Mato Dentro: km 126 (atual 115), 16 a 24 II. 1973, M. Sazima \& J.Semir 386 1, bot., fl. ô (SP); km 126 (atual 115), 30.IV.1973, J. Semir et al. 4151, fr. (RB); 16-24.II.1973, M. Sazima \& J.Semir 3861, bot., fl. ô (SP); idem, 30.IV. 1973, J. Semir et al 4151, bot.

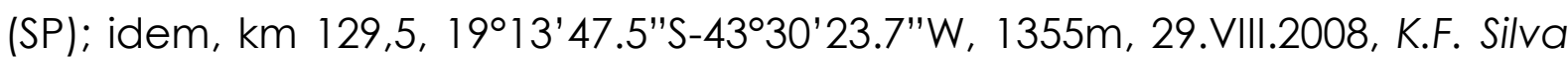
\& R.F. Oliani 84, fr. (CTES, SPF, SPFR); idem, km 139 (antigo 142); Santana do Riacho: Serra do Cipó, 11.V.1974, G. Martinelli 314, fr. jov. (RB); ao longo da rodovia Belo Horizonte-Conceição do Mato Dentro: km 142 (atual 139), 20.V.1974, J.Semir \& A.M. Giulietti 4994, fl. ô (RB, SP); idem, km 124 (atual 115), 08.VI.1980, A. Furlan \& J.R. Pirani CFSC 6212, fr. (CTES, SP); idem: km 119 (atual 
117), 01.Ill.1981, J.R. Pirani et al. CFSC 7091, bot., fl. o (SPF, SPFR); idem, 19016'37.6"S-4332'56.5"W, 1156m, 20.Il.2010, K.F. Silva \& T.P. Martins 165, fl. +, ô (CTES, RB, SPF, SPFR); 19016'38.8"S-4332'56.9'"W, 1164m, 16.VI.2007, K.F. Silva et al. 28, fr. (CTES, SPFR); Serra do Cipó: ca. 5 km após a bifurcação para Morro do Pilar, 05.VII.1996, V.C. Souza et al. 11740, fr. jov. (BHCB, CTES, ESA); Serra do Cipó: 17.Il.1972, W.R. Anderson et al. s/nº, bot. (RB); Córrego Três Pontinhas, 05.VII.1989, M.G.L. Wanderley et al. CFSC 11547, fr. (SPF, CTES); ca. 30km N of Serro on Road to Diamantina, 26.II.1968, H.S. Irwin et al. 20907, bot. (RB); km 130, estrada MG-010 ca. 400m antes da bifurcação entre o Morro do Pilar e Conceição do Mato Dentro, $1^{\circ}$ capão de mata à W da rodovia, 21.IX.1993, M.T.V.A. Campos \& E.D.P. de Souza CFSC 13383, fr. (SPF); idem 29.V.2010, K.F. Silva et al. 194, fr. (CTES, SPF, SPFR); idem, $2^{\circ}$ capão de mata à $W$ da rodovia, 04.III.1994, M.T.V.A. Campos \& J.M. Arcanjo CFSC 13653, bot., fl. ô (SP); idem, 27.I.1994, M.T.V.A. Campos CFSC \& J.P.M. Garcia 13619, bot., frutificando (SPF); idem, 19¹2"S-4330'W, 1349m, 14.VI.2007, K.F. Silva et al. 17 (SPFR); idem, K.F. Silva et al. 18 (SPFR); idem, K.F. Silva et al. 19 (SPFR); Conceição do Mato Dentro: Rio Santo Antonio, 1977, Paula s.n., fr. (RB); idem, próximo ao km 170, 800m, 16.VII.1977, G. Martinelli \& A. Távora 2590, fr. (RB); idem, há uns $15 \mathrm{~km}$ do município, 1903'26.5"S-43²5'38.2"W, 885m, 15.VIII.2009, K.F.Silva \& R.F. Oliani 128, fr. (SPF, SPFR); Morro do Pilar, trilha para o Rio Preto de Cima, 19015'05.6"S-4323'34.7"W, 767m, 13.VIII.2009, K.F. Silva \& R.F. Oliani 120, fr. (CTES, SPF, SPFR); idem, borda da estrada de terra MG 232 há uns $5 \mathrm{~km}$ de

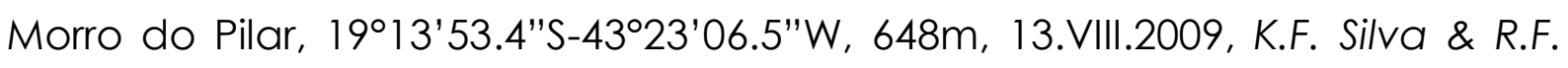
Oliani 126, fr. (SPFR); Itambé do Mato Dentro, Distrito de Santana do Rio Preto (Cabeça de Boi), 19²5'55.7"S-4326'05.6"W, 1033m, 28.V.2010, K.F. Silva 185 et al. (SPFR); idem, 19²3'51.6"S-4324'06.9"W, 701m, 28.V.2010, K.F. Silva et al. 175, bot. (SPF, SPFR).

Espécie endêmica do Brasil (Somner et al. 2010), ocorre nos estados da Bahia, Distrito Federal, Minas Gerais, Espírito Santo, Rio de Janeiro, Paraná, Santa Catarina e São Paulo: cerrado e mata atlântica (Somner 2009, Somner et al. 2010). Na Serra do Cipó esta espécie possui uma ampla distribuição, geralmente encontrada nas matas ciliares ou de galeria, capões de mata e 
também na APA Morro da Pedreira em Mata Seca; coletada com flores de janeiro a maio e com frutos em janeiro, abril a agosto e novembro.

Paullinia carpopoda foi facilmente identificada principalmente pelas folhas 3-4 jugas com folíolos basais 3-foliolados, presença de látex e fruto cápsula com carena; é muito semelhante a $P$. marginata diferindo nas nervuras secundárias que são mais retilíneas e numerosas e pelo pecíolo sempre marginado-alado; também P. marginata é endêmica do Rio de Janeiro (Somner et al. 2010).

8.2. Paullinia meliifolia Juss., Ann. Mus. Natl. Hist. Nat. 4: 347. 1804.

Prancha 3, fig. C-D.

Trepadeiras lactescentes, caule simples, ramos 5-costados, levemente sulcados, hirsutos ou pubescentes, lenticelas lineares e verrucosas. Folhas 3-4jugas, folíolos basais 3-foliolulados, pecíolo 2-9,5 cm compr., sulcado, estriado, 5-costado, raque alada, estípula 0,5-2 cm compr., foliácea ou cuneiforme; folíolos (2)3-11,5 × 1,2-5 cm, elípticos, oblongos, folíolo terminal ovado-rômbico, cartáceos, ápice acuminado, cuspidado ou obtuso, retuso, margem serreado-denteada do $2 / 3$ distal, base atenuada, aguda ou obtusa, oblíqua, face adaxial com poucos tricomas híspidos, adpressos, nervuras híspido-tomentosas, face abaxial glabra, com poucos tricomas hirsutos, adpressos, nervura média hirsuta ou tomentosa, venação craspedódroma ou semicraspedódroma, terciárias reticuladas; domácias barbadas, raro em bolsas. Tirso racemiforme, $8-16 \mathrm{~cm}$ compr., cincinos 3-5-floros, brácteas e bractéolas 2-4 mm compr. Flores 3-4 mm, sépalas 5, 2-3 mm, verdes e avermelhadas no centro, ovadas ou oblongas, cartácea-coriáceas, glabras ou hirsutas; pétalas 3-4 mm, brancas, obovadas, apêndice das pétalas com crista emarginada, lobos nectaríferos ovoides; flor 3 : estames 3-4 mm, filetes glabros, pistilódio piloso; flor +: estaminódios 2-3mm, ovário ovoide, glabro, estilete com ramos glandulosos. Cápsula 1,4 × 1,5 cm, vermelha, obovoide, orbicular, 3-alada, alas ocupam todo o comprimento do fruto, estípite $3 \mathrm{~mm}$ 
compr., epicarpo glabro ou piloso, endocarpo viloso. Sementes $1,1 \times 0,8 \mathrm{~mm}$, trígono-obovoides, negras, arilo cobrindo até $1 / 2$ da semente.

Material examinado: Minas Gerais, Santana do Riacho: Serra do Cipó,

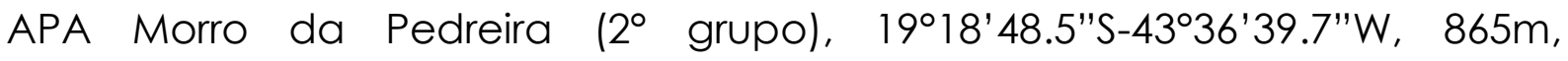

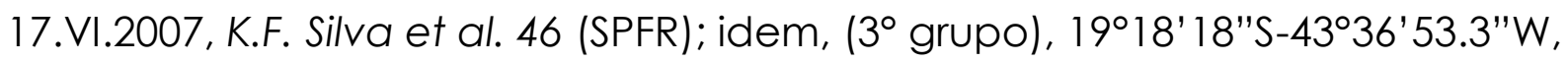
$877 \mathrm{~m}, 31 . V I I I .2008$, K.F. Silva \& R.F. Oliani 90 (SPFR); idem, 19018'36.7"S4336'44.1W, 976m, 31.V.2010, K.F. Silva et al. 205 (SPFR); Cardeal Mota, APA

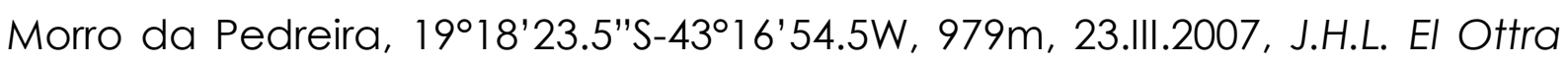
et al. 01, fr. (SPF, SPFR).

Material adicional examinado: Brasil, Rio de Janeiro, s.d., Commerson s.n., fr. (G, sintipo, foto F, negativo 23653); São Paulo: Pariquera-Açu, Estação Experimental do Instituto Agronômico, 2436'30"S-47052'37"W, 15.IX.1995, N.M. Ivanauskas 369, fl. ô (ESA, HRCB, IAC, MBM, PEL, RB, SPSF); Brotas, Fazenda Limoeiro, 30.V.2005, J.D. Urdampilleta \& J.I. Valio 277, fr. (SPFR, UEC); idem, Botucatu, Fazenda Edgardia, Unesp, $22^{\circ} 49^{\prime} S-48^{\circ} 23^{\prime}$ W, 4.XI.1995, R.C.B. Fonseca 11, fl. \& (ESA, SPFR).

Na América do Sul ocorre no nordeste da Argentina e na região leste do Paraguai (Somner 2009). No Brasil ocorre nos estados da Bahia, Distrito Federal, Minas Gerais, Espírito Santo, São Paulo, Rio de Janeiro, Paraná e Santa Catarina: mata de restinga e mata atlântica de encosta (Somner 2009, Somner et al. 2010). Na Serra do Cipó esta espécie foi principalmente encontrada na APA Morro da Pedreira, em afloramento rochoso e na Mata Seca; coletada com frutos em março.

P. meliifolia foi facilmente identificada mesmo vegetativamente por apresentar como principais características os folíolos hirsuto-pubescentes, membranáceos-cartácos, estípula foliácea e raque alada. 
8.3. Paullinia racemosa Wawra, Oesterr. Bot. Z. 29: 215. 1879.

Prancha 3, fig. F.

Trepadeira, caule simples, ramos cilíndricos, descamantes, glabros, lenticelas lineares e verrucosas. Folhas 5 -folioladas, folíolos basais com 2 foliólulos laterais reduzidos, pecíolo 0,9-1,4 cm compr. e raque subcilíndricos, levemente estriados, bicanaliculados, estípula 1,5 mm compr., oval; folíolos 2,1-9,0 x 0,5-4 cm, laterais basais reduzidos 2-6 mm compr., elípticos ou obovais, discolores, subcoriáceos, ápice caudado ou cuspidado, com glândula, margem inteira, revoluta, base atenuada, face adaxial e abaxial glabros, venação broquidódroma, terciárias reticuladas; domácias barbadas. Tirso racemiforme, 3-14 cm compr., cincinos 5-6-floros, brácteas e bractéolas $1 \mathrm{~mm}$ compr., triangular-subuladas, pilosas ou pubescentes. Flores brancas, 3-4 mm, sépalas 4, 1-2 mm, ovadas ou obovadas, coriáceas, pilosas ou pubescentes; pétalas $2 \mathrm{~mm}$, obovadas, glandular, apêndice petaloide com crista emarginada, lobos nectaríferos orbiculares; flor $\widehat{0}$ : estames 2-3mm, filetes pilosos, pistilódio glabro; flor q: estaminódios 1,5-2 mm, ovário trígonoobovoide, piloso. Cápsula 1-1,6 × 1-1,4 cm, vermelha, obovoide, 3-alada, alas ocupam todo o comprimento do fruto, ala ca. 0,8-1 cm larg., margem ondulada, estípite $1 \mathrm{~mm}$ compr., epicarpo estriado, glabro, endocarpo glabro, viloso na região das valvas. Sementes (1-2)-3, 0,3-1 cm compr., elípticas, arilo cobrindo até $2 / 3$ da semente.

Material examinado: Minas Gerais, Santana do Riacho, UCAT, 14.IV.1985, M.A. Lopes \& P.M. Andrade s.n., fr. (BHCB).

Material adicional examinado: Rio de Janeiro, Restinga em frente a Praia de Grumari, 2302'36.9"S-4331'56.3"W, 13m, 20.VII.2005, I.R. Costa et al. 593, fr. (UEC, SPFR); idem, Búzios, estrada para a Barra de São João, 9.I.1985, J.R. Pirani \& D.C. Zappi 1024, fl. ô (SPF, SPFR); Bahia, Ilhéus, II.1822, L. Riedel 616, fl. ㅇ (SPF).

Espécie endêmica do Brasil, presente nos estados do Pará, Maranhão, Ceará, Pernambuco, Alagoas, Bahia, Minas Gerais, Espírito Santo, Rio de 
Janeiro e São Paulo: mata atlântica de encosta (Somner 2009, Somner et al. 2010), na mata de restinga, na mata Atlântica e no carrasco (Somner 2001). Na Serra do Cipó parece ser rara com apenas uma coleta em área de UCAT; coletada com fruto em abril.

Paullinia racemosa foi facilmente identificada mesmo vegetativamente por apresentar como principais características as folhas 5folioladas, folíolos com margem inteira, laterais basais reduzidos, frutos alados e glabros.

8.4. Paullinia spicata Benth., J. Bot. (Hooker) 3: 193. 1851.

Prancha 3, fig. G-H.

Trepadeira, caule com 1 cilindro central e 2 periféricos, ramos estriados, 5-costados, levemente descamante, glabros, poucas lenticelas lineares. Folhas 5-foliolodas, pecíolo 5-9,3 cm compr. e raque marginados, estípula 1 mm compr., ovada, decídua, cicatriz semilunar; peciólulo 4-6 mm compr.; folíolos 7,5-13,7 x 4,0-5,5 cm, ovado-romboidais, cartáceos, ápice agudo ou acuminado, glândula submarginal, margem serreado-denteada no $2 / 3$ superior, base cuneada, face adaxial e abaxial glabros, venação craspedódroma, terciárias percorrentes; domácias barbadas. Tirso espiciforme, ca. $30 \mathrm{~cm}$ compr., cincinos 3-4-floros, brácteas e bractéolas 1-3 $\mathrm{mm}$ compr, subuladas, pubescentes. Flores branco-amareladas, 4-5 mm, sépalas 5, 3-4 mm, ovadas ou obovadas, coriáceas, pilosas ou pubescentes; pétalas $5 \mathrm{~mm}$, oblongo-estreitas, apêndice petaloide com crista erosa, lobos nectaríferos ovoides; flor 0 : estames $3-4 \mathrm{~mm}$, filetes pubescentes, pistilódio piloso; flor o: estaminódios 2-3mm, ovário ovoide, glabro, glanduloso, ramos do estigma glandulosos. Cápsula 2-3 x 1-1,7 cm, vermelha, turbinada, estípite $3 \mathrm{~mm}$ compr., epicarpo glabro e estriado, endocarpo glabro. Sementes (12)3, 1,3 cm compr., elípticas, arilo cobrindo quase toda a semente. 
Material examinado: Minas Gerais, São José da Cachoeira (Inhame), Santana de Pirapama, 18 59'21.7"S-4346'31.0"W, 650m, 05.III.2009, K.F. Silva et al. 109, fr. (CTES, SPF, SPFR).

Material adicional examinado: São Paulo, Álvares Florence, $20^{\circ} 19^{\prime} S$, 4954'W, 300-400m, 2.XI.1994, M.R. da Silva 1376, fl. ô, o (SPF).

Ocorre no Equador, Colômbia, Suriname, Guiana Francesa, nordeste do Paraguai e no Brasil, nos estados do Pará, Amazonas, Rondônia, Ceará, Mato Grosso, Mato Grosso do Sul, Minas Gerais, Rio de Janeiro, São Paulo e Paraná: mata ciliar (Somner 2009, Somner et al. 2010). Na Serra do Cipó parece ser rara com apenas uma coleta na porção oeste em Santana do Pirapama, em mata ciliar; coletada com fruto em março.

Paullinia spicata foi identificada principalmente pelo caule composto com 1 cilindro central e 2-3 periféricos, folhas 5 -folioladas e cápsula turbinada com epicarpo estriado. É morfologicamente afim a P. elegans Cambess. Segundo (Polo 2006), P. elegans possui tirsos solitários e racemiformes enquanto $P$. spicata possui tirsos espiciformes densifloros (sensu Radlkofer 1892) e está presente nos estados do Pará, Amazonas, Rondônia, Ceará, Mato Grosso, Mato Grosso do Sul, Minas Gerais, São Paulo, Rio de Janeiro e Paraná (Somner et al. 2010).

8.5. Paullinia trigonia Vell., Fl. Flumin.: 159. 1825; Icon. 30. 1829.

Prancha 3, fig. E.

Trepadeira não lactescente, caule simples, cilíndrico, ramos castanhoavermelhado, glabros ou pubérulos, indumento alvo, lenticelas lineares. Folhas 3-4-jugas, folíolos basais 3-foliolulados, pecíolo 1-3 cm compr., bicanaliculado, raque alada, estípula ovada, $1 \mathrm{~mm}$ compr.; folíolos 2-6,7 x 0,8-3,2 cm, elípticos ou obovais, folíolo terminal rômbico, discolores, cartáceos ou coriáceos, ápice agudo, com glândula, margem serreadodenteada do $1 / 2$ ou $2 / 3$ distal, pouco revoluta, base atenuada, face adaxial glabra, nervuras pilosas, face abaxial pilosa, venação craspedódroma mista, 
terciárias reticuladas; domácias barbadas e foveoladas. Tirso racemiforme, 3$9 \mathrm{~cm}$ compr., cincinos 4-5-floros, brácteas e bractéolas 0,5-1 mm compr, triangulares, pubescentes. Flores cremes, 4-5 mm, sépalas 4, 1-2 mm, ovadas, obovadas, coriáceas, pilosas ou pubescentes; pétalas 2-3 mm, obovadas, glabras, apêndice petaloide com crista erosa, lobos nectaríferos ovoides; flor ๙̃: estames 2-3 mm, filetes pubescentes, pistilódio glanduloso; flor p: estaminódios 1-2 mm, ovário trígono-ovoide, piloso, ramos do estigma glandulosos. Cápsula 1,5 × 0,8 cm, obovoide, avermelhada, 3-alada, alas 0,4$0,5 \mathrm{~mm}$ larg. ocupam todo o comprimento do fruto e são mais larga na porção mediana, estípite 1-3 mm compr., epicarpo rugoso, estriado, glabro, endocarpo tomentoso nas valvas. Sementes (2)-3, 0,7 x 0,6 mm, obovoides, arilo cobrindo até $1 / 2$ da semente.

Material examinado: Minas Gerais, Itambé do Mato Dentro, Distrito de Santana do Rio Preto (Cabeça de Boi), Serra do Cipó, 19²3'51.3"S4324'06.2"W, 708m, 28.V.2010, K.F. Silva et al. 177, fr. (SPF, SPFR); idem, Mata

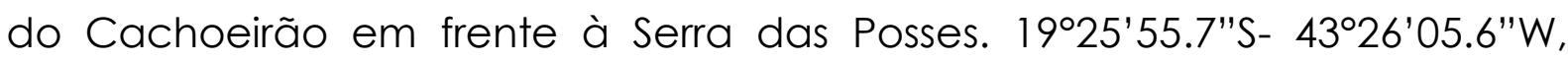
1033m alt., 28.V.2010, K.F. Silva et al. 181 (SPFR).

Material adicional examinado: Brasil, São Paulo, llha Anchieta, Trilha da Prainha, 07.ll.1996, H.F. Leitão Filho et al. 34483, fl. + (SPF); Minas Gerais, Parque Estadual do Rio Doce, trilha pisa de pouso/lagoa da Carioca, 19045'09"S- 42³7'59"'W, 263m, 26.I.1997, J.A. Lombardi 1567, fl. ô (BHCB, SPF).

Espécie endêmica do Brasil, ocorre no Pará, Pernambuco, Alagoas, Bahia, Minas Gerais, Espírito Santo, Rio de Janeiro, São Paulo, Paraná, Santa Catarina e Rio Grande do Sul, nos Domínios da Amazônia, Caatinga e Mata Atlântica (Somner et al. 2010). Na Serra do Cipó parece ser rara, encontrada na porção leste em Mata Estacional Semidecídua; coletada com fruto em maio.

Paullinia trigonia foi identificada principalmente pelas folhas 3-4-jugas com folíolos basais 3-foliolados, margem serreado-denteado, cápsula alada mais larga na porção mediana, domácias barbadas e foveoladas. Segundo Somner (2001) sensu Radlkofer (1892), P. trigonia é morfologicamente afim a P. micrantha e P. dasygonia diferindo na coloração do caule, filotaxia das 
folhas, margem foliar e distribuição geográfica, Somner (2001 ined.) designa ainda $P$. trigonia como sinonímia de P. micrantha, por ter constatado que os caracteres empregados para a separação dos táxons não sejam variáveis e não exclusivos.

\section{Serjania Mill.}

Trepadeiras lenhosas, escandentes ou raro subarbusto ereto, monoicas, glabras ou com indumento; caule simples ou composto, lactescentes ou não. Folhas imparipinadas, alternas, biternadas, 5-folioladas, 3-4-jugas ou triternadas; estípulas presentes; folíolos sésseis ou peciolulados, inteiros, denteados ou serreados; domácias presentes ou ausentes. Tirso racemiforme ou espiciforme, simples ou duplo, axilar ou terminal, cincinos, gavinhas na base da raque da inflorescência, brácteas e bractéolas presentes. Flores zigomorfas, brancas, cálice 4-5-mero, dialissépalo, persistente no fruto; corola 4-mera, pétalas ungüiculadas, geralmente glandulosas, apêndice petaloide com escama basal ciliada, vilosa, ápice com crista carnosa, amarelada; 4 lobos nectaríferos, 2 posteriores e 2 anteriores menores, glabros; androceu: estames de tamanho desiguais, filetes geralmente achatados, glabros ou com indumento, anteras elipsoides, glabras, pistilódio reduzido; gineceu 3carpelar, 3-locular, 1 óvulo por carpelo, estilete filiforme, estigma 3-fido. Fruto esquizocárpico, 3 mericarpos samaroides, porção seminífera na parte distal do mericarpo, lóculos dilatados ou achatados, pericarpo glabro ou com indumento, endocarpo glabro ou com indumento; sementes achatadas ou não.

Serjania é um gênero americano com aproximadamente 233 espécies distribuídas do sul dos Estados Unidos até o centro da Argentina e Uruguai (Ferrucci et al. 2009). No Brasil ocorrem 117 espécies, sendo 64 endêmicas, encontradas nos Domínios da Amazônia, Caatinga, Cerrado, Mata Atlântica e Pantanal (Somner et al. 2010). 
Na Serra do Cipó ocorrem 18 espécies, a maioria das espécies foi encontrada em regiões mais secas, no cerrado e em afloramento rochoso no Morro da Pedreira, corroborando com dados de Acevedo-Rodríguez (1993).

\section{Chave para as espécies de Serjania}

1.Caule simples.

2.Ramos 5-6 alados; estípula ovada; término das nervuras entre os dentes da margem dos folíolos ciliada.......................................................18. S. tristis

2'.Ramos não alados; estípula não ovada; término das nervuras entre os dentes da margem dos folíolos não ciliada

3.Ramos jovens geniculados, lactescentes, folíolos com face adaxial glabra e face abaxial glabra a pubescente, domácias ausentes, apêndice petaloide com crista bífida, fruto glabro, lóculos no ápice dilatados, crista dorsal não revoluta

9.16. S. reticulata 3'.Ramos não geniculados, não lactescentes, folíolos com face adaxial hirto ou pubescente, face abaxial velutina ou tomentosa, domácias barbadas ou foveoladas, apêndice petaloide com crista erosa, fruto pubescente ou híspido, lóculos no ápice lateralmente achatados, crista dorsal revoluta

9.1. S. acoma

1 '.Caule composto.

4.Caule com 5 cilindros radialmente dispostos

5.Ramos hirto-pubescentes ou setoso-hirsutos, caule costado, folíolos setoso-hirtelos; fruto 3-4 cm compr., oblongo, lóculos no ápice lateralmente achatados, setosos, crista dorsal revoluta, alas pilosas

9.4. S. deflexa

5'.Ramos não hirto-pubescentes ou setoso-hirsutos, caule cilíndrico ou estriado, folíolos não setoso-hirtelos; fruto 1-2,5 cm compr., ovado- 
cordado, lóculos no ápice dilatados, glandulares, crista dorsal não revoluta, alas glabras 9.12. S. paradoxa

4'.Caule com 1 cilindro central e 1-10 cilindros periféricos

6.Caule com 1 cilindro central e 1-5 periféricos menores que o central 7.Folhas biternadas

8.Caule com cilindros periféricos não equidistantes, pecíolo com mais de $2 \mathrm{~cm}$ compr., apêndice petaloide com crista bipartida

9.Caule com (1)2(3) cilindros periféricos, caule descamante; fruto com os lóculos glabros ou escassos tricomas glandulares dispersos, constrição leve abaixo do lóculo, crista dorsal 1,5-2 mm larg., endocarpo glabro................................9.7. S. marginata 9'.Caule com 3-5 cilindros periféricos, quando mais de 3 disposto aos pares, caule pruinoso; fruto com os lóculos velutinos, forte constrição abaixo do lóculo, crista dorsal 0-1 mm larg., endocarpo piloso........................................6. S. lethalis 8'.Caule com 3 cilindros periféricos eqüidistantes, pecíolo com menos de $2 \mathrm{~cm}$ compr., apêndice petaloide com crista erosa ou bífida

10.Folhas com raque não alada, folíolos com venação craspedódroma mista; tirso com cincinos 3-4-floros, flores $4 \mathrm{~mm}$ compr. 9.2. S. acutidentata

10'.Folhas com raque alada, folíolos com venação semicraspedódroma; tirso com cincinos 5-6-floros, flores 5-6 $\mathrm{mm}$ compr. 9.10. S. obtusidentata

7'.Folhas 5-folioladas ou 3-jugas

11.Ramos pubescentes, pecíolo até $1 \mathrm{~cm}$ compr., fruto cordado, viloso. 9.11. S. paludosa

11 '.Ramos glabros, pecíolo com mais $1 \mathrm{~cm}$ compr., fruto ovado, ovado-cordado ou largo elíptico, não viloso 12. Cilindros periféricos do caule 2 ou 3 complanados; fruto com alas pubescentes 9.13. S. perulacea 
12'. Cilindros periféricos do caule não complanados; fruto com alas glabras

13.Folíolos coriáceos, pecíolo e raque alados, domácias ausentes, apêndice petaloide com crista bífida. 9.5. S. erecta 13.Folíolos cartáceos, pecíolo e raque não alados, domácias barbadas, apêndice petaloide com crista erosa 9.17. S. tripleuria

6'.Caule com 1 cilindro central e 7-10 cilindros periféricos

14.Caule com 10 cilindros periféricos, folíolos com margem denteada no $2 / 3$ inferior 9.9. S. noxia 14'.Caule com 7-8 cilindros periféricos, folíolos com margem denteada no $2 / 3$ superior

15. Cilindros periféricos de tamanho iguais ao central, folhas 5folioladas, folíolos com face abaxial pubescente, fruto com lóculos viloso. 9.14. S. pinnatifolia 15'. Cilindros periféricos de tamanho não iguais ao central, folhas biternadas, folíolos com face abaxial não pubescente, frutos com lóculos não vilosos

16.Folhas com venação semicraspedódroma, domácias ausentes, não lactescente; lobos nectaríferos menores triangulares 9.8. S. multiflora 16'.Folhas com venação craspedódroma mista, domácias barbadas, lactescente; lobos nectaríferos menores orbiculares

17.Ramos glabros, folíolos com face adaxial não brilhante, face abaxial não púrpuro-castanha e sem utrículos laticíferos; flores $8 \mathrm{~mm}$ compr., apêndice petaloide com crista bífida; fruto retangular, constrição acentuada abaixo do lóculo, crista dorsal ausente. 9.3. S. caracasana 
17'.Ramos pubescentes, folíolos com face adaxial brilhante, face abaxial púrpuro-castanha e com utrículos laticíferos; flores $3 \mathrm{~mm}$ compr., apêndice petaloide com crista erosa ou inteira; fruto ovalcordado, constrição ausente abaixo do lóculo, crista dorsal $0,5 \mathrm{~mm}$ larg

9.15. S. purpurascens

9.1. Serjania acoma Radlk. Consp. Sect. Sp. Serjan. 5. 1874.

Prancha 3, fig. I.

Trepadeira, caule simples, ramos 5-6 costados, velutinos, lenticelas ausentes ou presentes e verrucosas. Folhas biternadas, pecíolo $0,8-3 \mathrm{~cm}$ compr., canaliculado e raque marginada ou bicanaliculada, tomentosohirsutos, estípula 1-4 mm compr., subulada, pilosa; folíolos 0,5-8 x 0,5-4,7 cm, os laterais bem menores que o terminal, ovados, elípticos ou obovados, discolores, cartáceos, ápice agudo, acuminado ou obtuso, mucronado, geralmente com glândula apical, margem inteira ou denteado-serreada no $1 / 2$ ou $2 / 3$ superior, alguns com glândula apical, base decurrente no folíolo terminal, cuneada nos folíolos laterais, face adaxial hirto ou pubescente, às vezes avermelhada, face abaxial tomentosa ou velutina, venação semicraspedódroma; domácias em bolsas e foveoladas. Tirso racemiforme, 6-15 cm compr., cincinos 4-floros, hirsutos, tomentosos, brácteas e bractéolas 1-4 mm compr., lineares, pubescentes. Flores 4-5 mm compr., sépalas 5, ovadas ou obovadas, híspidas ou tomentosas; pétalas obovadas, glabras, apêndice petaloide com crista erosa; lobos nectaríferos ovoides, laterais elípticos; flor 3 : estames 3-4 mm compr., filetes achatados, pilosos, pistilódio piloso; flor o: estaminódios $2 \mathrm{~mm}$, ovário trígono-obovado, pubescente, ramos do estigma glandulosos. Fruto $2 \times 1,5-2 \mathrm{~cm}$, róseo, oval-retangular, lóculos no ápice lateralmente achatados, pubescentes ou híspidos, sem constrição abaixo dos lóculos, crista dorsal 2-4 mm larg., revoluta, alas pubescentes, 
endocarpo glabro; sementes 2-4 × 1-4 mm, elipsoides, achatadas lateralmente, inseridas na base dos lóculos.

Material examinado: Minas Gerais, Santana do Riacho, Serra do Cipó: estrada de terra sentido Santana do Riacho, Morro da Pedreira ( $2^{\circ}$ grupo), 19०18'48.5"S-4336'39.7"W, 865m, 17.VI.2007, K.F. Silva et al. 44, fl. o, fr. (CTES, RB, SPF, SPFR); idem, 19०18' 18.4"S-4336'47.9"'W, 935m, 17.VI.2007, K.F. Silva et al. 47, fr. (CTES, SPF, SPFR); idem, Morro da Pedreira (2० grupo), 19०18'38.7"S4337'17.7"W, 1318m, 24.IX.2007, K.F. Silva et al. 62 (SPFR); idem, Morro da

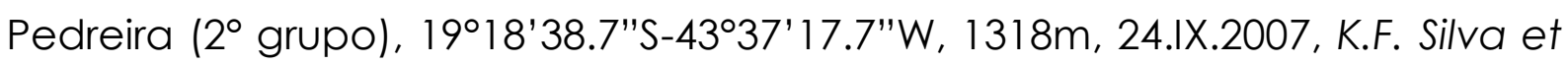
al. 65, fr. (CTES, SPF, SPFR); idem 19017'08.5"S-4337'59.6"W, 770m, 20.ll.2010, K.F. Silva \& T.P. Martins 156, fl. ô (CTES, SPF, SPFR); idem, Morro da Pedreira $\left(2^{\circ}\right.$

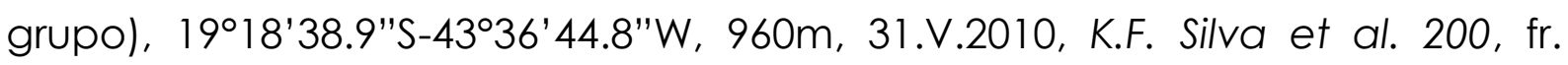
(BHCB, CTES, MBM, RB, SPF, SPFR); idem Morro da Pedreira (3० grupo), 19018'18.0"S-4336'53.3"W, 877m, 31.VIII.2008, K.F. Silva \& R.F. Oliani 89, fl. ô, fr. (CTES, SPFR).

Material adicional examinado: Brasil, São Paulo, VII.1898, Sello 5380, fl., fr. (B, sintipo, foto $F$, negativo 5532).

Na América do Sul ocorre no Paraguai e no Brasil nos estados de Minas Gerais, São Paulo, Paraná e Santa Catarina (Ferrucci 1993, Ferrucci et al. 2009, Somner et al. 2010), também nos estados do Nordeste e Mato Grosso do Sul, nos Domínios do Cerrado e Mata Atlântica (Somner et al. 2010). Na Serra do Cipó foi encontrada em afloramento rochoso, na região da APA Morro da Pedreira; coletada com flor em fevereiro, junho e agosto e frutos em maio, junho, agosto e setembro.

Serjania acoma foi identificada principalmente pelo caule simples, indumento velutino por toda a planta, fruto com lóculos no ápice lateralmente achatados, pubescentes ou híspidos, sem constrição abaixo dos lóculos e crista dorsal revoluta. É morfologicamente afim a S. comata diferindo apenas pelos tricomas hirsutos no caule e setoso-comosos nos lóculos presentes em S. comata. Embora ocorra em Minas Gerais S. comata não foi encontrada na Serra do Cipó. 
9.2. Serjania acutidentata Radlk., Consp. Sect. Sp. Serjan.: 11 1. 1874.

Prancha 3, fig. J-K.

Trepadeira, caule composto, 1 cilindro central e 3 cilindros periféricos eqüidistantes, ramos 6 costados, 3 costas angulares e 3 obtusos, triangulares, glabros. Folhas biternadas, pecíolo $0,7-2(4) \mathrm{cm}$ compr. e raque bicanaliculados ou marginados, pruinosos, estípula $1 \mathrm{~mm}$ compr., obovada

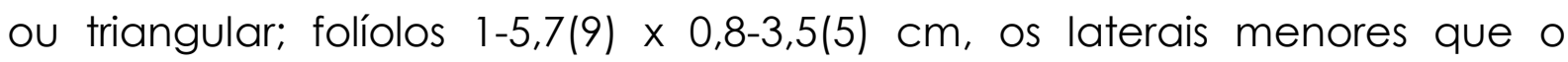
terminal, elípticos, lanceolados ou obovados, discolores, cartáceos a coriáceos, ápice obtuso em 1 dos folíolos laterais e com glândula, agudo ou acuminado, margem denteada, 2-5(8) dentes no 1/2 superior, dentes com glândula subapical, base aguda ou obtusa, raro assimétrica, face adaxial glabra, face abaxial incano ou glabra, venação craspedódroma mista; domácias ausentes. Tirso racemiforme, $5-21 \mathrm{~cm}$ compr., cincinos 3-4-floros, pubescentes, brácteas e bractéolas 1-2 mm, subuladas. Flores 4 mm compr., sépalas 5, ovadas, pubescentes ou tomentosas, glandulares; pétalas espatuladas, glabras, ciliadas, apêndice petaloide com crista erosa; lobos nectaríferos orbiculares; flor ${ }^{*}$ : estames $3-5 \mathrm{~mm}$ compr., filetes cilíndricos, pilosos, pistilódio glabro; flor q: estaminódios 2-3 mm compr., pilosos, ovário obovoide, glandular. Fruto avermelhado, 1,3-2,7 x 1-1,5 cm, ovado-cordado, lóculos no ápice dilatados, pubescentes ou hirsutos, sem constrição abaixo dos lóculos, crista dorsal $1 \mathrm{~mm}$ larg., alas pilosas, endocarpo glabro; sementes 3-4 × 2-3 mm, esféricas, inseridas na base dos lóculos.

Material examinado: Minas Gerais, Distrito de Três Barras, Serra do Cipó: estrada de terra sentido cachoeira três barras, borda da trilha, 1905'53.7"S-

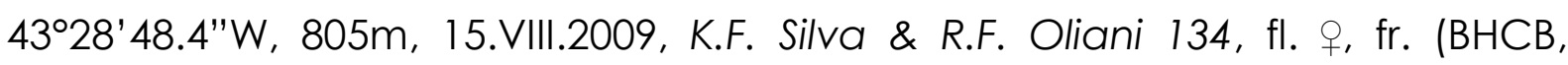
CTES, RB, SPF, SPFR); idem, Santana do Riacho: as margens do Córrego Véu da Noiva, 01.VII.1981, A.M. Giulietti et al. CFSC 7421, fl. +, fr. (CTES, SPF); Km 107 caminho para Usina Dr. Pacifico Mascarenhas, 07.IX.1980, E. Forero et al. 7979, fr. (SP, SPF); idem, 20.VIII.1985, D.C. Zappi CFSC 9344, fl. $\hat{o}$,, , fr. (SPF); na 
orla da rodovia MG-010, $72 \mathrm{~km}$ desde Conceição, 21.VIII.1986, P. AcevedoRodríguez et al. 1506 (RB); idem, km 104 da rodovia MG-010 (Belo HorizonteConceição do Mato Dentro), 19¹8'56.4"S-43³6'19.1"'W, 798m, 01.IX.2008, K.F. Silva \& R.F. Oliani 93, fl. ㅇ, fr. (SPFR); idem, trilha dos escravos, 19¹8'52"S43036'24.3"W, 875m, 30.VIII.2008, K.F. Silva \& R.F. Oliani 86, fr. (BHCB, CTES, RB, SPF, SPFR); Jaboticatubas, PARNA Serra do Cipó: base da cachoeira da

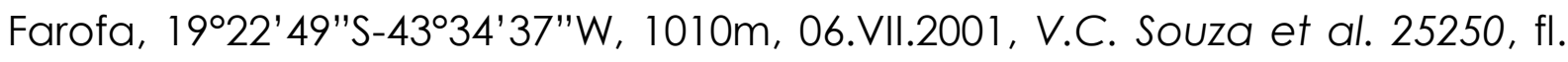
+. fr. (ESA); idem, ca. $300 \mathrm{~m}$ da cachoeira da Farofa, 19²2'47.9"S4334'38.1 "W, 804m, 22.IX.2007, K.F. Silva et al. 52, fl. ㅇ, fr. (CTES, SPF, SPFR); ca. $1 \mathrm{~km}$ da cachoeira da Farofa, 19²2'47.9"S-43³4'38.1"W, 804m, 22.IX.2007, K.F. Silva et al. 51 (SPFR); Distrito de São José da Cachoeira (Inhame), Santana de Pirapama, Trilha da Senhorinha, 1857'48.7"S-4346'46.6"W, 706m, 06.III.2009, K.F. Silva et al. 117 (SPFR); idem, trilha sentido base da Serra (paredão rochoso), com início na estrada de terra próximo a Fazenda Toucan Cipó (do Inglês), 1859' 48.6"S-4346'02.0"W, 724m, 06.III.2009, K.F. Silva et al. 104 (SPFR); Conceição, na orla da rodovia MG-010, de Conceição do Mato Dentro até Lagoa Santa; $7 \mathrm{~km}$ desde Conceição, 700-800m, 21.VIII.1986, P. Acevedo-Rodríguez et al. 1503, fl. o, fr. (RB); Itambé do Mato Dentro. Distrito de Santana do Rio Preto (Cabeça de Boi), Terras do Zé

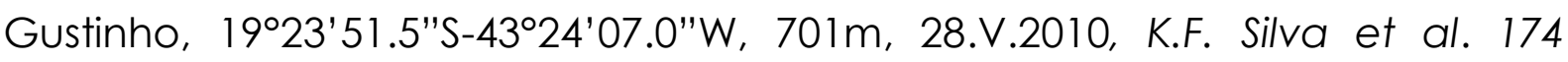
(SPFR).

Espécie endêmica do Brasil, ocorre nos estados da Bahia, Minas Gerais e São Paulo, nos Domínios da Caatinga e Cerrado (Somner et al. 2010); na Serra do Cipó foi encontrada em cerrado e em mata ciliar; coletada com flor e fruto em julho, agosto e setembro.

Serjania acutidentata foi identificada principalmente pelo caule composto, 1 cilindro central e 3 cilindros periféricos eqüidistantes, ramos 6 costados, 3 costas angulares e 3 obtusos, triangulares; folíolos elípticos, lanceolados ou obovados, ápice obtuso em 1 dos folíolos laterais e com glândula, agudo ou acuminado, margem denteada, 2-5(8) dentes no 1/2 superior. É morfologicamente afim a Serjania obtusidentata diferindo no pecíolo marginado ou alado e raque alada presentes em $S$. obtusidentata. 
9.3. Serjania caracasana (Jacq.) Willd., Sp. Pl. Editio quarta 2(1): 465. 1799.

Prancha 3, fig. L-M.

Trepadeira, caule composto, 1 cilindro central e 7-8 cilindros periféricos menores que o central, ramos cilíndricos, estriados, glabros ou pruinosos, lactescentes, lenticelas lineares, verrucosas ou ausentes. Folhas biternadas, pecíolo 3,5-5,3 cm compr., canaliculado e raque bicanaliculada, glabros ou pruinosos, estípula $1 \mathrm{~mm}$ compr., triangular; folíolos 2,5-12 x 2,2-4,1 cm, os laterais menores, elípticos, oblongos ou ovados, discolores, cartáceos, ápice acuminado, obtuso ou retuso em alguns folíolos laterais, glândula apical, margem repando-denteada, dentes no 1/2 superior, geralmente com glândula subapical, base decurrente no folíolo terminal, atenuada, cuneada ou aguda nos folíolos laterais, face adaxial glabra ou pruinosa, face abaxial glabra, venação craspedódroma mista; domácias barbadas. Tirso racemiforme, (8) 15-40 cm compr., cincinos 4-5-floros, pilosos a pubescentes, brácteas e bractéolas 0,5-1 mm, subuladas. Flores $8 \mathrm{~mm}$ compr., sépalas 5 , ovadas, pubescentes ou glabras, ciliadas; pétalas espatuladas, obovadas, pilosas, apêndice petaloide com crista bífida; lobos nectaríferos ovoides, menores orbiculares; flor $\hat{\jmath}$ : estames $5-7 \mathrm{~mm}$ compr., filetes achatados, pilosos, pistilódio glabro; flor o: estaminódios 3-4 mm compr., ovário obovoide, glanduloso, ramos do estigma glandulosos. Fruto avermelhado, 2,9 x 2,4 cm, retangular, lóculos dilatados, glabros, quando secos mais escuros que a ala, constrição acentuada abaixo do lóculo, crista dorsal ausente, alas glabras, nervuras proeminentes, endocarpo glabro; sementes $5 \times 6 \mathrm{~mm}$, arredondadas, inseridas na base dos lóculos.

Material examinado: Minas Gerais, Santana do Riacho, Serra do Cipó:

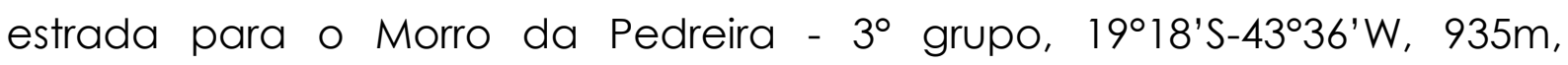
17.VI.2007, K.F. Silva et al. 36, fl. q (CTES, RB, SPF, SPFR); 19018'18.4"S4336'47.9"W, 935m, 17.VI.2007, K.F. Silva et al. 39, bot. (CTES, RB, SPF, SPFR); idem, km 104 da rodovia MG-010 (Lagoa Santa-Conceição do Mato Dentro), 
APA Morro da Pedreira - $2^{\circ}$ grupo, 22.VII.1993, N. Roque et al. CFSC 13270, fl.

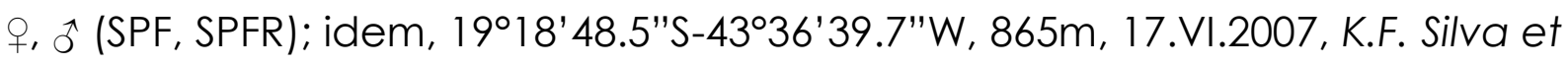
al. 42, fl. ㅇ (BHCB, CEPEC, CTES, MBM, SPF, SPFR); 19¹8'36.7"S-4336' 44.1"W, 976m, 31.V.2010, K.F. Silva et al. 206, fl. q (BHCB, CTES, RB, SPF, SPFR); Conceição do Mato Dentro, Rio Santo Antonio, 800m, 1977, Paula s.n., fr. (RB).

Ocorre no México, Guatemala, Costa Rica, Cuba, Venezuela, Colômbia, Peru, Bolívia, Uruguai, Paraguai e Argentina (Ferrucci 1993, Ferrucci et al. 2009). No Brasil ocorre nos estados de Roraima, Amapá, Pará, Amazonas, Acre, Rondônia, Piauí, Paraíba, Pernambuco, Bahia, Mato Grosso, Goiás, Distrito Federal, Mato Grosso do Sul, Minas Gerais, Espírito Santo, São Paulo, Rio de Janeiro e Paraná, nos Domínios da Amazônia, Caatinga, Cerrado, Mata Atlântica e Pantanal (Somner et al. 2010). Na Serra do Cipó foi encontrada principalmente em área de afloramento rochoso, na região da APA Morro da Pedreira e em mata ciliar; coletada com flor em maio, junho e julho.

Serjania caracasana foi identificada principalmente pelo caule composto, 1 cilindro central e 7-8 cilindros periféricos menores que o central, ramos lactescentes, estípulas marrom em contraste com o caule verde, domácias barbadas nos folíolos; flores $8 \mathrm{~mm}$ compr., fruto retangular, lóculos dilatados, quando secos mais escuros que a ala e constrição acentuada abaixo do lóculo. É uma espécie polimórfica (Acevedo-Rodríguez 1987). É morfologicamente afim a Serjania tripleuria diferindo no caule composto, 1 cilindro central e 3-4 cilindros periféricos, quando 3 equidistantes e quando 4, 2 cilindros estão pareados, 3-angulares, não lactescente; folhas 5-folioladas e margem dos folíolos denteada, 4-5 dentes no 1/2 superior, presentes e característicos em S. tripleuria. 


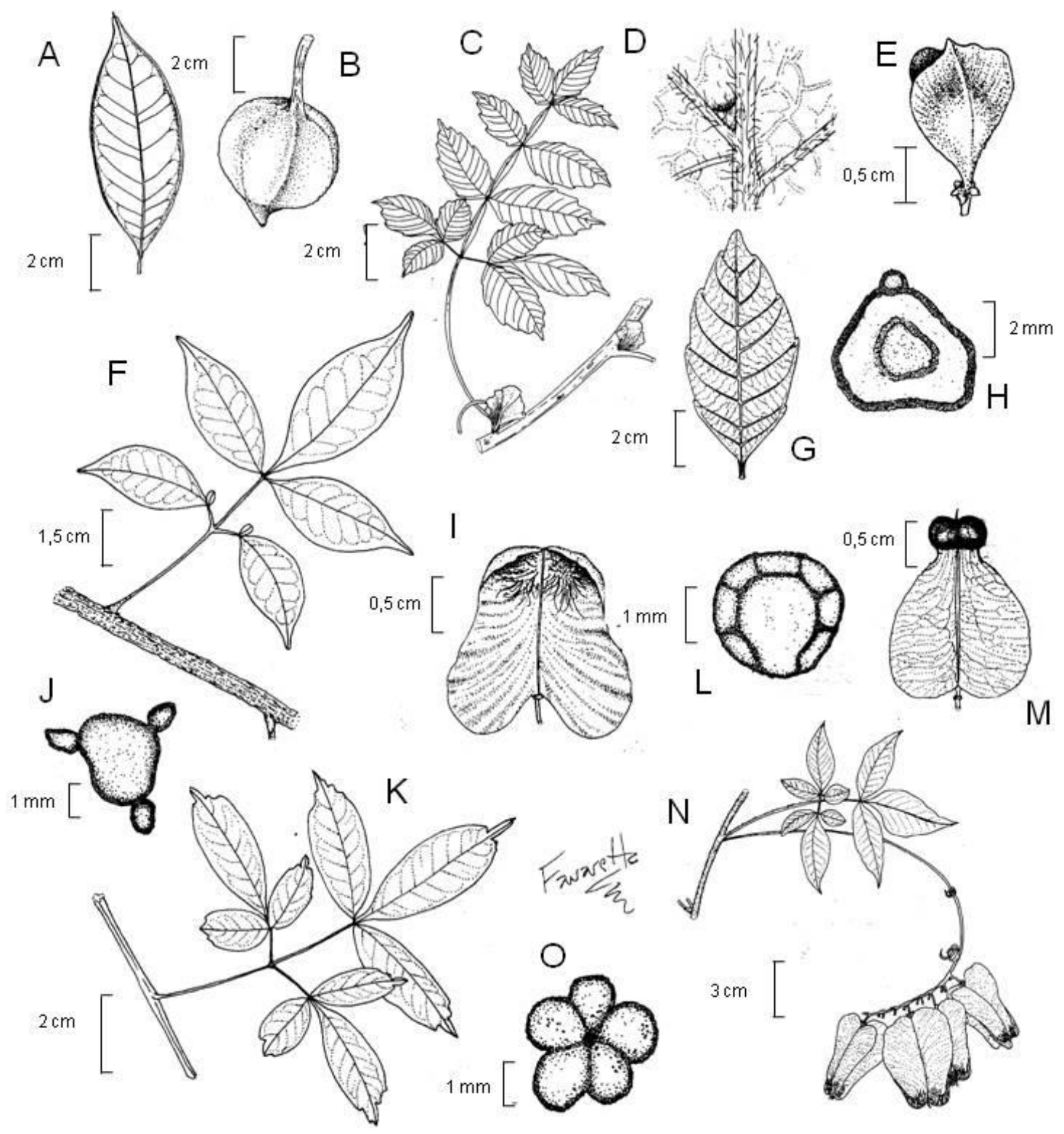

Prancha 3. A-B. Paulinia carpopoda, A. folíolo; B. fruto. C-D. Paulinia melifolia, C. ramo, mostrando a estípula foliácea ou cuneiforme; D. detalhe da face abaxial do folíolo mostrando a domácia urceolada. E. Paulinia trigonia, fruto. F. Paulinia racemosa, folha. G-H. Paulinia spicata, G. folíolo; H. caule, corte transversal. I. Serjania acoma, fruto. J-K. Serjania acutidentata, J caule, corte transversal; K. folha. L-M. Serjania caracasana, L. caule,corte transversal, M. fruto. N-O Serjania defiexa, N. ramo frutífero; $O$. caule, corte transversal. (A-B, Silva \& Oliani 84; C-D, Silva et al. 205; E, Silva et al. 177, F, Lopes \& Andrade s.n.; G-H. Silva et al. 109; I. Silva et al. 44; J-K Silva ef al. 52; L-M. Paula s.n.; N-O, Silva \& Oliani 147.) llustraçốes: Favaretto. 
9.4. Serjania deflexa Gardner, London J. Bot. 2: 337. 1843.

Prancha 3, fig. N-O.

Trepadeira, caule composto, 5 cilindros radialmente dispostos, ramos 5 costados, geniculados, hirto-pubescentes ou setoso-hirsutos, glandulosas. Folhas biternadas, pecíolo 2-4,5 cm compr. e raque bicanaliculados, hirtelos; estípula $2 \mathrm{~mm}$ compr., subulada, hirtela; folíolos 1,5-7,5 x 0,5-3,5 cm, elípticos, folíolo terminal subrômbico, discolores, cartáceos, ápice agudo, acuminado ou mucronado, arredondado em 1 dos folíolos laterais, geralmente com glândula apical, margem inteira, raro 1-2 dentes, ciliada, base atenuada no folíolo terminal, obtuso nos folíolos laterais, face adaxial setosa, glandular, face abaxial hirtela e glandular, venação broquidódroma, craspedódroma mista; domácias ausentes ou em bolsa ou barbadas. Tirso racemiforme, pubescentes, 18-23 cm compr., cincinos 5-6-floros, brácteas e bractéolas 1-2 $\mathrm{mm}$, lineares ou subuladas. Flores $5-7 \mathrm{~mm}$ compr., sépalas 5, cuculadas, ovadas, hirtas e glandulosas, pétalas obovadas, glabras, apêndice petaloide com crista erosa ou inteira; lobos nectaríferos ovoides, menores orbiculares; flor 3: estames 3-5 mm compr., filetes achatados, pilosos, pistilódio glanduloso; flor + : estaminódios $3 \mathrm{~mm}$, ovário trígono-ovoide, glanduloso, ramos do estigma glandulosos. Fruto róseo, 3-3,7 × $2 \mathrm{~cm}$, oblongo, lóculos no ápice lateralmente achatados, setosos, constrição ausente abaixo do lóculo, crista dorsal $0,5 \mathrm{~mm}-1 \mathrm{~cm}$ larg., revoluta, alas pilosas, glandulares, endocarpo glabro ou viloso, glandular; sementes $3-4 \mathrm{~mm}$, lenticulares, inseridas na base dos lóculos.

Material examinado: Minas Gerais, Conceição do Mato Dentro, Serra do Cipó: borda da MG 010 após bifurcação Conceição do Mato Dentro Morro do Pilar, ca. 10km, 19¹0'44.1"S-4330'46.5"W, 1342m, 17.VIII.2009, K.F. Silva \& R.F. Oliani 147, fr. (CTES, SPF, SPFR); idem, ca. 20km, 1909'44.0"S4330'17.7"W, 610m, 17.VIII.2009, K.F. Silva \& R.F. Oliani 145, fr. (CTES, RB, SPF, SPFR). 
Material adicional examinado: Minas Gerais, Rio Preto, estrada do Vilarejo do Funil, 21.V.2004, K. Antunes et al. 133, fl. ㅅ․ + (CESJ, SPFR); Brasil, 1832, Lhotsky, fl., fr. (G, sintipo, foto $F$, negativo 23664).

Espécie endêmica do Brasil, ocorre nos estados de Minas Gerais, Espírito Santo, São Paulo e Rio de Janeiro, no Domínio da Mata Atlântica (Somner et al. 2010). Vegeta mata de encosta (Ferrucci et al. 2009). Na Serra do Cipó foi encontrada em área de bosque e mata secundária com plantação de Eucalyptus sp.; coletada com fruto no mês de agosto.

Serjania deflexa foi identificada principalmente pelo caule composto com 5 cilindros radialmente dispostos, ramos 5 costados, hirto-pubescentes ou setoso-hirsutos, glandulares; folíolos com ápice agudo ou acuminado, mucronado, arredondado em 1 dos folíolos laterais, margem inteira, raro 1-2 dentes, ciliada; fruto oblongo, lóculos no ápice lateralmente achatados, setosos, crista dorsal $0,5 \mathrm{~mm}-1 \mathrm{~cm}$ larg., revoluta. É morfologicamente afim a S. paleata, diferindo principalmente por causa dos tricomas paleáceos (achatados e brilhantes) nos lóculos dos frutos de S. paleata, e embora $S$. paleata ocorra em Minas Gerais não foi encontrada na Serra do Cipó.

\subsection{Serjania erecta Radlk., Monogr. Serjania 8. 1874.}

Prancha 4, fig. A-B.

Subarbusto 0,40 - $2 m$ alt., caule composto, 1 cilindro central e 1-3 cilindros periféricos menores que o central, ramos descamantes, cilíndricos, glabros ou pruinosos, as vezes fistulosos, lactescentes, lenticelas lineares, verrucosas. Folhas 5-folioladas ou raro 3-jugas, pecíolo $4-15 \mathrm{~cm}$ compr. e raque alados, glabros, estípula $1 \mathrm{~mm}$ compr., triangular; folíolos 3,3-10 × 2-5,5 cm, elípticos ou ovados, terminal rômbico, discolores, coriáceos, ápice acuminado ou mucronado, glândula apical, margem serreado-denteada no 1/2 superior, dentes com glândula subapical, base decurrente no folíolo terminal, atenuada, cuneada ou aguda nos demais, face adaxial glabra, face abaxial glabra, glandular, venação craspedódroma; domácias 
ausentes. Tirso racemiforme, $10-26 \mathrm{~cm}$ compr., cincinos 2-4-floros, pubescentes, brácteas e bractéolas 0,5 - $1 \mathrm{~mm}$, triangulares ou subuladas. Flores 4-6 mm compr., sépalas 5, ovadas, pubescentes; pétalas espatuladas, glandulosas, apêndice petaloide com crista bífida; lobos nectaríferos ovoides, menores triangulares; flor $\widehat{0}$ : estames $5-6 \mathrm{~mm}$ compr., filetes achatados, glabros, pistilódio glabro; flor q: estaminódios 3-4 mm compr., ovário obovoide, glabro, estilete maior que os ramos do estigma, ramos glandulosos. Fruto amarelado, 2,5-3,5 cm, ovado, largo-elíptico, lóculos no ápice dilatados, glabros, denso glandulosos, constrição ausente abaixo do lóculo, crista dorsal 1-2 mm larg., alas glabras, lustrosas, endocarpo glabro; sementes 2-8 mm, esféricas, inseridas na base dos lóculos.

Material examinado: Minas Gerais, Distrito de São José da Cachoeira (Inhame), Santana de Pirapama, Serra do Cipó: 1859'43.7"'S-4346'36.3"W, 686m, 05.III.2009, K.F. Silva et al. 106, fl. ․, fr. (SPFR); Santana do Riacho, estrada Santana do Riacho-Lapinha, 1904'S-4342'W, 1090m, 05.III.1998, J.R. Pirani et al. 4244, fl. q (CTES, SPF); Jaboticatubas, PARNA Serra do Cipó: caminho da base do lbama do Rio Cipó para o Capão dos Palmitos, 950m, 25.III.1991, J.R. Pirani et al. CFSC 12029, bot. (CTES, SPF); idem, trilha Capão dos Palmitos, 19²1'54.3"S-4337'14.6"W, 941m, 27.VIII.2008, K.F. Silva \& R.F. Oliani 77 (SPFR); idem, 500m da portaria principal do parque, 19०21'01.9"S4336'39.5"W, 805m, 30.V.2010, K.F. Silva et al. 198, fr. (CTES, SPF, SPFR); Jaboticatubas, São José de Almeida, 16.ll.2001, A.F. Silva 38, fl. q (BHCB); Congonhas do Campo, 18.V.1892, F.Magalhães 440, fl. ․, fr. (BHCB).

Material adicional examinado: Minas Gerais, Joaquim Felício, estrada para Rio da Onça, 1110m, 20.ll.2003, F.F. Mazine et al. 813, fl. §ૈ (BHCB, CTES, ESA).

Na América do Sul é encontrada na Bolívia, Paraguai e Brasil (Ferrucci 1993, Ferrucci et al. 2010), nos estados do Acre, Rondônia, Ceará, Mato Grosso, Goiás, Distrito Federal, Mato Grosso do Sul, Minas Gerais, São Paulo e Paraná, nos Domínio da Amazônia e Cerrado (Somner et al. 2010). Na Serra 
do Cipó foi encontrada no cerrado, em solo pedregoso, arenoso; coletada com flor em fevereiro, março e maio e fruto em março e maio.

Serjania erecta foi identificada principalmente pelo caule composto com cilindro central e 1-3 cilindros periféricos menores que o central, ramos geralmente fistulosos, lactescentes; folhas 5 -folioladas ou raro 3 -jugas, pecíolo e raque alados; folíolos coriáceos; fruto ovado, largo-elíptico, lóculos no ápice dilatados, constrição ausente abaixo do lóculo. É morfologicamente afim a S. dibotrya, espécie encontrada na Bolívia e Perv e que não ocorre no Brasil.

9.6. Serjania lethalis A. St-Hil., Hist. PI. Remarq. Bresil 1: 206. 1824.

N.V.: Timbó

Prancha 4, fig. C.

Trepadeira escandente, caule composto, 1 cilindro central e 3-4 cilindros periféricos, menores que o central, quando 3 eqüidistantes, quando 4-(5), dispostos em pares, ramos cilíndricos, estriados, quando mais velho triangular, pruinosos, lactescentes, lenticelas lineares ou verrucosas. Folhas biternadas, pecíolo 3-8 cm compr., canaliculado, raque bicanaliculada, alada ou marginada, glabros ou pubérulos, estípula $1 \mathrm{~mm}$ compr., triangular; folíolos 2,3-13 x 1-5,5 cm, laterais menores, elípticos, obovados, discolores, cartáceos, ápice agudo, obtuso, acuminado, com glândula apical, margem inteira ou repando-denteada, $2-5$ dentes, no 1/2 superior, com glândula apical, base atenuada folíolos terminal, base aguda nos demais folíolos, face adaxial brilhante, glabra, face abaxial glabra, venação broquidódroma, craspedódroma mista ou semicraspedódroma; domácias ausentes. Tirso duplo, racemiforme, 7,5-35 cm compr., cincinos 3-5-floros, pubescentes, brácteas e bractéolas 1-2 mm, lineares. Flores odoríferas, 4-5 mm compr., sépalas 5, cuculadas, ovadas, oblongas ou obovadas, pubescentes ou tomentosas; pétalas espatuladas, obovadas, glandulosas, apêndice petaloide com crista bipartida; lobos nectaríferos, ovados, menores 
orbiculares; flor t: estames $3-5 \mathrm{~mm}$ compr., filetes achatados, pilosos, pistilódio glabro; flor p: estaminódios 2-4 mm compr., ovário oblanceolado, glabro ou viloso. Fruto vermelho ou castanho-esverdeado, 1-2,9 x 0,8-1,9 cm, ovado-cordado, cordado-retangular, lóculos no ápice dilatados, velutinos, forte constrição abaixo do lóculo, crista dorsal 0-1mm larg., alas glabras, pilosas ou pubescentes, endocarpo piloso; sementes 2-3 x 1-2 mm, arredondadas ou elípticas, inseridas na base dos lóculos.

Material examinado: Minas Gerais, Jaboticatubas, PARNA Serra do Cipó: trilha do poço azul, 19¹7'15"S-4335'20"W, 1198m, 15.VI.2007, K.F. Silva et al. 21, bot. ( SPFR); idem, ca. 1,5km da cachoeira da Farofa na trilha

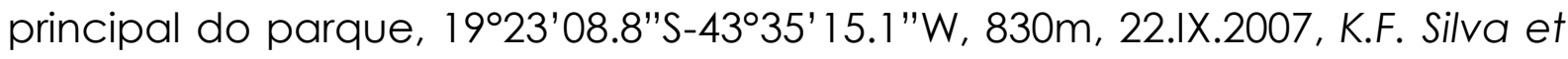
al. 50, fr. (BHCB, CEPEC, CTES, RB, SPF, SPFR); idem, atrás do alojamento e laboratório para pesquisadores na sede do Ibama, 19²0'57.7"S4337'07.4"W, 809m, 22.IX.2007, K.F. Silva 60, fl. ㅇ, fr. jov. (BHCB, CEPEC, CTES, MBM, RB, SPF, SPFR); idem, lado direito da trilha principal do parque com início na sede do Ibama, há uns 200m, 19¹7'15"S-4335'20"W, 809m, 15.VI.2007, K.F. Silva et al. 20, bot. (CTES, RB, SPF, SPFR); idem, trilha principal

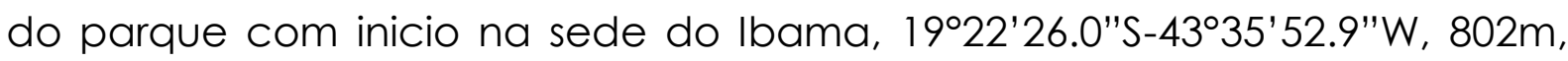
22.IX.2007, K.F. Silva et al. 54, fl. ô, fr. jov. (BHCB, CEPEC, CTES, MBM, RB, SPF,

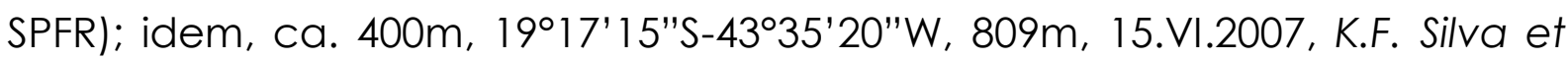

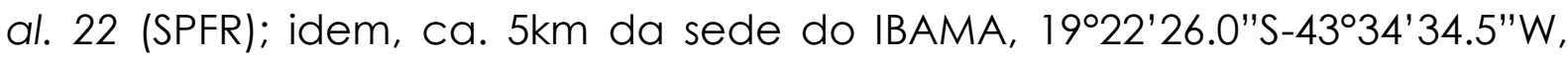
802m, 22.IX.2007, K.F. Silva et al. 55, fl. ô, fr. (SPF, SPFR); idem: ca. $4 \mathrm{~km}$ da sede

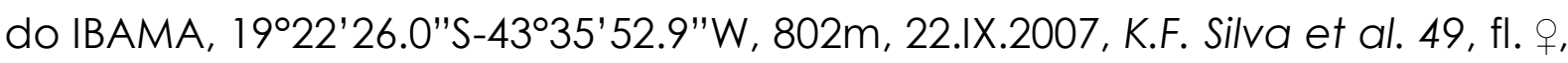
fr. (CTES, RB, SPF, SPFR); idem, na orla da rodovia MG-010, de Conceição do Mato Dentro para Lagoa Santa, $13 \mathrm{~km}$ antes de Lagoa Santa, 600m, 21.VIII.1986, P. Acevedo-Rodríguez et al. 1508, fl. o (RB); idem, $16 \mathrm{~km}$ antes de Lagoa Santa, 700-800m, 21.VIII.1986, P. Acevedo-Rodríguez et al. 1505, fl. \$. o + (RB); Santana do Riacho: Morro da Pedreira (2' grupo), 19018'48.5"S4336'39.7"W, 865m, 17.VI.2007, K.F. Silva et al. 45 (SPFR); idem, 19¹8'38.7"S433' 17.7"W, 1318m, 24.IX.2007, K.F. Silva et al. 63, fl. ㅇ (BHCB, MBM, SPF, SPFR); idem, K.F. Silva et al. 61, fr. (CTES, SPF, SPFR); idem, K.F. Silva et al. 66, fr. 


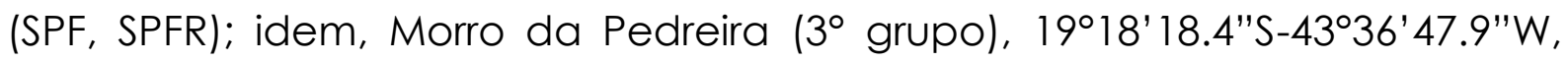
935m, 17.VI.2007, K.F. Silva et al. 38, bot. (BHCB, CTES, SPF, SPFR); estrada para a cachoeira da Caverna, 19¹5'09.9"S-4335'07.1"'W, 1062m, 23.IX.2007, K.F. Silva et al. 57, fr. (CEPEC, CTES, MBM, RB, SPF, SPFR); km 104 da rodovia MG010 (Lagoa Santa-Conceição do Mato Dentro), 15.X.1982, G.L. Esteves \& M.L. Kawasaki CFSC 9043, fr. (CTES, SPF); idem, km 93 estrada de terra ao lado do Córrego João Congo, 19²2' 51.3"S-43³9'24.9"W, 850m, 02.IX.2008, K.F. Silva \& R.F. Oliani 96 (SPFR); idem, km 95 da rodovia MG-010 (Lagoa SantaConceição do Mato Dentro) trilha para o mirante da Fazenda e Pousada Monjolos, 19²0'33.0"S-4338'33.8"W, 789m, 01.IX.2008, K.F. Silva \& R.F. Oliani 92, fl. $\hat{\alpha}$, o , fr. jov. (SPF, SPFR); idem, sede da Fazenda Monjolos, 24-27.IX.2002, L.S. Kinoshita et al. 02/129, fr. (UEC); idem, Lagoa Comprida, caminho para a cachoeira da Farofa, 07.IX.1987, M.G.L. Wanderley et al. CFSC 10606, fl. ô, o (CTES, SP, SPF); Vale do Rio Cipó, arredores da cachoeira Grande, 29.VII.1991, A.M. Giulietti et al. CFSC 12681, bot., fl. o( SPF, SPFR); idem, entre a sede do Ibama e o Canyon das Bandeirinhas, 19²3'S-4335' W, 985m, 06.VII.2001, V.C. Souza et al. 25273, bot. (ESA); Serra do Cipó, IX.1897, J.P. Oliveira 4066, fl. ô (BHCB); idem, 23.XI.1987, G. Schmeda 1061 et al. (BHCB); Conceição do Mato Dentro, Serra do Cipó: ca. 10km de Conceição do Mato Dentro, 1905'23.9"S-4327'06.4"W, 790m, 15.VIII.2009, K.F. Silva \& R.F. Oliani 133, bot. (CTES, MBM, SPF, SPFR); idem, estrada de terra para o Distrito Tabuleiro, 19001'10.5"S-4330'51.1"W, 802m, 16.VIII.2009, K.F. Silva \& R.F. Oliani 138, fl. ô, 우 frutificando (CTES, SPF, SPFR); idem, 1901'35.1"S-4331'32.6"W, 774m, 16.VIII.2009, K.F. Silva \& R.F. Oliani 140, fl. ô, क (CTES, SPF, SPFR); idem, $19^{\circ} 01^{\prime} 25.2^{\prime \prime S}-43^{\circ} 29^{\prime} 18.3^{\prime \prime} \mathrm{W}, 762 \mathrm{~m}, 16 . \mathrm{VIII} .2009$, K.F. Silva \& R.F. Oliani 141, fl. ô, o, fr. jov. (CTES, SPF, SPFR); Cardeal Mota, estrada em frente à Pousada Monjolo, trilha do Paredão, próximo à cachoeira, 24.IX.2002, L.S. Kinoshita et al. C-033, fr. (UEC).

Material adicional examinado: Brasil, 1829, St. Hilaire, fl. (B, sintipo, foto $F$, negativo 5560).

Na América do Sul ocorre na Bolívia, Peru e Brasil (Ferrucci et al. 2009), nos estados do Amapá, Amazonas, Acre, Piauí, Ceará, Pernambuco, Bahia, 
Mato Grosso, Goiás, Distrito Federal, Mato Grosso do Sul, Minas Gerias, São Paulo, Rio de Janeiro, Paraná e Santa Catarina, nos Domínios da Amazônia, Caatinga, Cerrado, Mata Atlântica e Pantanal (Somner et al. 2010); vegeta mata seca semidecídua, mata de planalto, cerradão e mata atlântica de encosta (Ferrucci et al. 2009). Na Serra do Cipó foi encontrada em quase toda a região, cerrados, matas ciliares, matas secundárias e afloramento rochoso, na área do PARNA possui um crescimento desenfreado, se tornando invasora principalmente nas regiões perturbadas ou com influência antrópica e nos campos graminosos por não possuir outras espécies para apoiar possui um comportamento de moita; coletada com flor em junho, julho, agosto e setembro e fruto em setembro e outubro.

Serjania lethalis foi identificada principalmente pelo caule composto com 1 cilindro central e 3-4 cilindros periféricos, menores que o central, quando 3 eqüidistantes, quando 4-(5), dispostos em pares, ramos pruinosos, lactescentes; tirso 7,5-35 cm compr., flores articuladas, fruto ovado-cordado ou cordado-retangular, lóculos no ápice dilatados, velutinos, forte constrição abaixo do lóculo. É uma espécie polimórfica (Ferrucci com. pess.). Morfologicamente afim a S. perulacea e S. scopulifera, diferindo principalmente nas folhas que são triternadas ou depauperadas e 5foliolada, respectivamente. E S. scopulifera não ocorre em Minas Gerais.

9.7. Serjania marginata Casar., Nov. Stirp. Bras. Decades 5: 44. 1843.

Prancha 4, fig. D.

Trepadeira, caule composto, 1 cilindro central e 2(3) cilindros periféricos, menores que o central, ramos cilíndricos, descamantes, glabra. Folhas biternadas, pecíolo 2,5-6,5 cm compr., alado, raque alada, glabros, estípula 1-2 mm compr., triangular; peciólulo alado; folíolos 2-9,5 x 1,5-4 cm, ovados, obovados ou elípticos, discolores, cartáceos, ápice agudo ou acuminado, mucronado, com glândula apical, margem inteira ou denteada, 1-3 dentes no 1/3 superior, glândula subapical, base decurrente no 
folíolo terminal, aguda ou cuneada nos demais, face adaxial glabra, opaca, face abaxial glabra, opaca, venação craspedódroma mista ou broquidódroma; domácias ausentes. Tirso racemiforme, 10 - 15 cm compr., 35 -floros, tomentoso-velutinos ou incano-pubescentes, brácteas e bractéolas 1-2 mm, lineares ou subuladas. Flores 3-5 mm compr., sépalas 5, ovadas, cuculadas, pubérulas, tomentosa-velutinas ou incano-pubescentes; pétalas espatuladas, pilosas, glandulares, apêndice petaloide com crista bipartida; lobos nectaríferos ovoides, menores orbiculares; flor 3 : estames 2-4 mm compr., filetes achatados, pilosos, pistilódio glabro; flor o: estaminódios 2$3 \mathrm{~mm}$, ovário obovoide, glabro. Fruto 1-5 - 1,8 x 1,8 cm, ovado-cordado ou ovado-retangular, lóculos no ápice dilatados, glabros ou escassos tricomas glandulares dispersos, constrição leve abaixo do lóculo, crista dorsal 1,5-2mm larg., alas glabras, lustrosas, endocarpo glabro; sementes 2-4 × $4 \mathrm{~mm}$, elipsoides, inseridas na base dos lóculos.

Material examinado: Minas Gerais, Santana do Riacho, Serra do Cipó: Km 104 da rodovia MG-010 (Lagoa Santa-Conceição do Mato Dentro). APA Morro da Pedreira ( $2^{\circ}$ grupo), subida pela Pousada Grande Pedreira, 19¹8'38.7"S- 4336'45.2"W, 958m, 31.V.2010, K.F. Silva et al. 223 (SPFR).

Material adicional examinado: Minas Gerais, Uberlândia, Reserva Ecológica do Panga, 08.V.1987, G.M. Araújo 190, fl. \& (CTES, HUFU); Bahia, Barauninha, Santana do Riacho, 19.IV.1996, G. Hatschbach et al. 65057, fl. ㅇ, fr. (CTES, MBM).

Na América do Sul ocorre na Bolívia, Argentina, Paraguai (Ferrucci 1993, Ferrucci et al. 2009) e Brasil, nos estados de Tocantins, Rondônia, Pernambuco, Bahia, Mato Grosso, Goiás, Distrito Federal, Minas Gerais, São Paulo, Rio de Janeiro e Paraná, nos Domínios da Amazônia, Caatinga, Cerrado, Mata Atlântica e Pantanal (Somner et al. 2010). Na Serra do Cipó parece restrita a APA Morro da Pedreira; coletada apenas em estado vegetativo.

Serjania marginata foi identificada principalmente pelo caule composto com 1 cilindro central e 2(3) cilindros periféricos, menores que o 
central, folíolos com raque marginada ou alada, peciólulo alado e fruto ovado-cordado ou ovado-retangular. É morfologicamente afim a S. lethalis diferindo principalmente no número e disposição dos cilindros periféricos e superfície do caule e ramos, já citados anteriormente.

9.8. Serjania multiflora Cambess., Fl. Bras. Merid. (quarto ed.) 1:365. 1828.

Prancha 4, fig. E.

Trepadeira, caule composto, 1 cilindro central e 8 cilindros periféricos, menores que o central, ramos cilíndricos, estriados, pruinosos ou pubescentes, lenticelas verrucosas. Folhas biternadas, pecíolo $3-5,7 \mathrm{~cm}$ compr., canaliculado, raque bicanaliculada, glabros ou pubescentes, estípula $1 \mathrm{~mm}$ compr., subulada; folíolos 4-7,8 $\times$ 2,3-3,5 cm, ovados ou elípticos, discolores, cartáceos, ápice agudo ou acuminado, mucronado, obtuso nos folíolos laterais e basais, com glândula apical, margem serreadodenteado no 1/2 superior, dentes com glândula, base atenuada, cuneada, face adaxial brilhante, glabra, face abaxial glabra ou hirta, escassos pontos translúcidos, venação semicraspedódroma; domácias ausentes. Tirso espiciforme, 6 - $15 \mathrm{~cm}$ compr., cincinos 3-5-floros, incanos ou pubescentes, brácteas e bractéolas $1 \mathrm{~mm}$, triangulares. Flores 3-4 3 mm compr., sépalas 4 , ovadas ou obovadas, cuculadas, pubérulas, pubescentes ou tomentosavelutinas; pétalas espatuladas, pilosas, glandulares, apêndice petaloide com crista bífida ou emarginada; lobos nectaríferos triangulares, menores ovoides, resinosos; flor $\sigma^{*}$ : estames $3 \mathrm{~mm}$ compr., filetes achatados, pilosos, pistilódio glabro; flor p: estaminódios 2-3 mm, ovário obovoide, pubescente. Fruto $3 \mathrm{x}$ $1,5 \mathrm{~cm}$, ovado-cordado, lóculos no ápice dilatados, pubescentes, constrição acentuada abaixo do lóculo, crista dorsal 0-1 mm larg., alas glabras ou pubérulas, endocarpo glabro; sementes $5 \times 4 \mathrm{~mm}$, elipsoides, inseridas na base dos lóculos. 
Material examinado: Minas Gerais, Santana do Riacho, Serra do Cipó, rodovia MG-010, Belo Horizonte-Conceição do Mato Dentro, km 87,5, ao longo do rio Cipó, 1.VII.1981, A.M. Giulietti et al. CFSC 7384, fl. ơ (SPF, SPFR).

Material adicional examinado: Minas Gerais, Poços de Caldas, $21^{\circ} 50^{\prime 2} 20^{\prime \prime S}-46^{\circ} 3353^{\prime \prime}$ W, 17.VI.1982, H.F. Leitão Filho et al. 1670-A, fl. ô, q (UEC); São Paulo, Parque Estadual, 29.VIII.1951, W. Hoehne s/n., fr. (SPF).

No Brasil ocorre nos estados do Pará, Distrito Federal, Minas Gerais, São Paulo, Rio de Janeiro, Paraná e Santa Catarina, nos Domínios da Amazônia, Cerrado e Mata Atlântica (Somner et al. 2010). Vegeta em mata semidecídua, cerradão e mata ciliar (Ferrucci et al. 2009). Na Serra do Cipó foi encontrada principalmente em áreas de mata ciliar; coletada com flor em julho.

Serjania multiflora foi identificada principalmente caule composto com 1 cilindro central e 8 cilindros periféricos, menores que o central, ramos cilíndricos, estriados, pruinosos ou pubescentes, folíolos com face adaxial brilhante; fruto ovado-cordado, lóculos no ápice dilatados, constrição acentuada abaixo do lóculo. É morfologicamente afim a S. perulacea, S. lethalis e S. scopulifera, diferindo vegetativamente pelo número de cilindros periféricos no caule que para essas 3 espécies chega a 5.

9.9. Serjania noxia Cambess, Fl. Bras. Merid. (quarto ed.) 1: 363. 1828.

Prancha 4, fig. F.

Trepadeira, caule composto, 1 cilindro central e 10 cilindros periféricos menores que o central, ramos estriados, glabros ou tomentosos, lactescentes, poucas lenticelas lineares. Folhas biternadas, pecíolo 1 - 5,5 cm compr., canaliculado, raque marginada ou bicanaliculada, glabros ou tomentosos, estípula $1 \mathrm{~mm}$ compr., triangular; folíolos $1-8 \times 0,6-5 \mathrm{~cm}$, laterais menores e desiguais entre si, elípticos, alguns laterais obovados, discolores, cartáceos, ápice obtuso em 1 folíolo lateral, acuminado ou mucronado, alguns laterais 
com glândula apical, margem inteira, geralmente 1-2 (6) dentes no $1 / 3^{-2} / 3$ inferior dos folíolos, ciliada, base atenuada no folíolo terminal, cuneada no folíolo lateral, face adaxial glabra, glandular, nervuras pilosas, face abaxial glabra, pilosa, venação broquidódroma; domácias ausentes. Tirso subracemiforme, 10-15 cm compr., cincinos 2-3-floros, pubescentes, brácteas e bractéolas 1-2 mm, subuladas. Flores 3-5 mm compr., sépalas 5, ovadas, coriáceas, tomentosas; pétalas espatuladas, apêndice petaloide com crista erosa; lobos nectaríferos ovoides, menores orbiculares; flor s: estames 3-5 mm compr., filetes achatados, pilosos, anteras elipsoides, pistilódio glabro; flor + : estaminódios 2-3 mm compr., ovário obovoide, glabro. Fruto vermelho, 1,42,5 x 1,7 cm, ovado-cordado, lóculos no ápice dilatados, pilosos, pruinosos, constrição ausente abaixo do lóculo, crista dorsal ausente, alas glabras, endocarpo viloso; sementes 1,5-5 × 1-3 mm, elípticas, achatadas lateralmente, inseridas na base dos lóculos.

Material examinado: Minas Gerais, Santana do Riacho, Serra do Cipó: estrada para Conceição do Mato Dentro, km 124, 30.IV.1989, L.C. Giordano 681, fl. $\hat{\jmath}$, + , fr. (RB, SPFR); ca. $15 \mathrm{~km}$ de Conceição do Mato Dentro, 1903'26.4"S-4325'38.2"W, 887m, 15.VIII.2009, K.F. Silva \& R.F. Oliani 129, fr. (CTES, RB, SPF, SPFR); Conceição do Mato Dentro, na orla da rodovia MG-010, (de Conceição do Mato Dentro para Lagoa Santa); 7 km desde Conceição, 700-800m, 22.VIII.1986, P. Acevedo-Rodríguez et al. 1504, fr. (RB), idem, Distrito de Tabuleiro, Serra do Cipó, borda da estrada de terra sentido Tabuleiro,

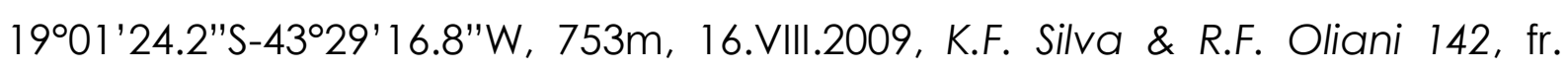
(CTES, SPF, SPFR); Itambé do Mato Dentro, Distrito de Santana do Rio Preto (Cabeça de Boi), 19²3'51.7"S-4324'06.2"W, 701m, 28.V.2010, K.F. Silva et al. 171 (SPFR); idem Mata do Cachoeirão em frente a Serra das Posses, 19²5'55.7"S-4326'05.6"W, 1034m, 28.V.2010, K.F. Silva et al. 182 (SPFR).

Material adicional examinado: Brasil, Minas Gerais, St. Hilaire, fl. (P, sintipo, foto F, negativo 36047); Brasil, Rio de Janeiro, Pohl 690, fl. (B, sintipo, foto $F$, negativo 5565). 
No Brasil ocorre nos estados do Pará, Amazonas, Rondônia, Maranhão, Mato Grosso do Sul, Minas Gerais, São Paulo e Rio de Janeiro, nos Domínios da Amazônia, Cerrado e Mata Atlântica (Somner et al. 2010). Na Serra do Cipó foi encontrada em Floresta Estacional Semidecídua e em capão de mata; coletada com flor no mês de abril e fruto em abril e agosto.

Serjania noxia foi identificada principalmente caule composto com 1 cilindro central e 10 cilindros periféricos menores que o central, ramos lactescentes; folíolos com margem inteira ou geralmente 1-2 (6) dentes no 1/3 inferior dos folíolos, ciliada, venação broquidódroma; fruto ovado-cordado, lóculos no ápice dilatados, pilosos, pruinosos, constrição ausente abaixo do lóculo, crista dorsal ausente. É morfologicamente afim a S. fluminensis, diferindo nas folhas 5 -folioladas, folíolos coriáceos e distrivição geográfica já que S. fluminensis não ocorre em Minas Gerais.

9.10. Serjania obtusidentata Radlk., Consp. Sect. Sp. Serjan.: 11. 1874.

Prancha 4, fig. G.

Trepadeira, caule composto, 1 cilindro central e 3 cilindros periféricos equidistantes, ramos 6-costados, 3 costas obtusas e 3 agudas, estriados, glabros ou pubérulos. Folhas biternadas, pecíolo $0,8-2 \mathrm{~cm}$ compr., marginado ou alado, raque alada, glabros, pilosos, estípula $1 \mathrm{~mm}$ compr., triangular; folíolos 2,2-9,5 x 1,5-4,2 cm, laterais menores, elípticos ou ovados, discolores, coriáceos, ápice agudo, obtuso nos folíolos laterais, com glândula apical, margem denteada $1 / 2$ superior, base cuneada, face adaxial e abaxial glabras, glandulares, venação semicraspedódroma; domácias ausentes. Tirso racemiforme, cincinos 4-6-floros, tomentosos, 10-21 cm compr., brácteas e bractéolas $1 \mathrm{~mm}$, subuladas. Flores odoríferas, 5-6 mm compr., sépalas 5, ovadas, glabras ou tomentosas; pétalas espatuladas, apêndice petaloide com crista bífida; lobos nectaríferos orbiculares; flor 3 : estames 3-5 $\mathrm{mm}$ compr., filetes achatados, pubescentes, pistilódio glabro; flor ;: estaminódios 3-4 mm compr., ovário obovoide, glabro. Fruto róseo, 2 × 1,5 
cm, ovado-cordado, lóculos no ápice dilatados, velutinos, constrição ausente abaixo do lóculo, crista dorsal $1 \mathrm{~mm}$ larg., alas pubérulas, endocarpo pubescente; sementes $2 \times 1 \mathrm{~mm}$, elipsoides, inseridas na base dos lóculos.

Material examinado: Minas Gerais, Santana do Riacho, km 105 ao longo da rodovia Lagoa Santa-Conceição do Mato Dentro, Córrego Chapéu de Sol, 22.VIII.1980, I. Cordeiro 6435 \& J.R. Pirani, fl.o (CTES, SP); vale do Córrego Chapéu de Sol, 12.X.1980, M.C. Henrique Mamede CFSC 6629 et al., fl. ڤે, fr. jov. (CTES, SP).

Espécie endêmica do Brasil, ocorre nos estados de Pernambuco, Mato Grosso, Minas Gerais, São Paulo e Rio de Janeiro, nos Domínios do Cerrado e Mata Atlântica (Somner et al. 2010). Na Serra do Cipó foi encontrada principalmente em área de mata ciliar; coletada com flor em agosto e outubro e fruto em outubro.

Serjania obtusidentata foi identificada principalmente pelo caule composto com 1 cilindro central e 3 cilindros periféricos equidistantes, ramos 6-costados, 3 costas obtusas e 3 agudas, estriados; folhas com pecíolo marginado ou alado, raque alada; folíolos ovados, coriáceos; flores 5-6 mm compr.; fruto ovado-cordado, lóculos no ápice dilatados, velutinos, constrição ausente abaixo do lóculo. É morfologicamente afim a $S$. acutidentata diferindo no pecíolo pouco marginado ou não alado e raque não alada em S. acutidentata.

9.1 1. Serjania paludosa Cambess., Fl. Bras. Merid. (quarto ed.) 1: 368. 1824.

Prancha 4, fig. $\mathrm{H}$.

Trepadeira, caule composto, 1 cilindro central e 3-4 cilindros periféricos, menores que o central, quando 3 equidistantes, ramos trígonos, levemente 3angular, estriados, tomentosos, pubescentes ou vilosos. Folhas 5-folioladas, pecíolo 0,4 - 0,9 cm compr., canaliculado ou marginado, raque bicanaliculada, pubescentes, estípula $4 \mathrm{~mm}$ compr., linear ou subulada; 
folíolos 1,5-4,7 x 1,5-2,9cm, elípticos, terminal rômbico, discolores, cartáceos, ápice obtuso ou acuminado, mucronado no folíolo terminal, com glândula, margem denteada ou inciso serreada, base decurrente no folíolo terminal, obtusa nos folíolos laterais, face adaxial pubescente, face abaxial velutina, venação craspedódroma; domácias ausentes. Tirso espiciforme, cincinos 3floros, pubescentes, $5-10 \mathrm{~cm}$ compr., brácteas e bractéolas $1 \mathrm{~mm}$, ovadas. Flores 3-4 mm compr., sépalas 5, ovadas, pubérulas ou pubescentes; pétalas espatuladas, glandulares, apêndice petaloide com crista bífida; lobos nectaríferos orbiculares; flor 3 : estames $3-5 \mathrm{~mm}$ compr., filetes achatados, glabros, pistilódio glabro; flor p: estaminódios $2 \mathrm{~mm}$ compr., ovário trígonoobcordiforme, pubescente. Frutos jovens 1 x 1,3-2,2 cm, cordados, lóculos no ápice dilatados, vilosos, constrição ausente abaixo do lóculo, crista dorsal $1 \mathrm{~mm}$ larg., alas vilosas, endocarpo viloso, ferrugíneo; sementes $2 \times 1 \mathrm{~mm}$, elipsoides, inseridas na base dos lóculos.

Material examinado: Minas Gerais, Distrito de São José da Cachoeira (Inhame), Santana de Pirapama, borda da estrada de terra após córrego da Fazenda Toucan Cipó, 1859'21.7"S-4346'31.0"W, 650m, 05.III.2009, K.F. Silva et al. 107, fl. + , fr. (CTES, K, SPF, SPFR).

Material adicional examinado: Minas Gerais, Conselheiro Mata, Distrito de Rodeador, estrada Conselheiro Mata-Monjolos, 03.III.1999, F. Feres et al. 99/30, fl. $\hat{o}$, fr. (CTES, SPFR, UEC); Brasil, Minas Gerais, St. Hilaire, fl., fr. (P, sintipo, foto F, negativo 36048).

No Brasil ocorre nos estados da Bahia e Minas Gerais, nos Domínios da Caatinga e Cerrado (Somner et al. 2010). Na Serra do Cipó parece rara sendo encontrada apenas na região de Santana de Pirapama, em área perturbada, como borda de estrada; coletada com flor e fruto no mês de março.

Serjania paludosa foi identificada principalmente pelo caule composto com 1 cilindro central e 3-4 cilindros periféricos, menores que o central, quando 3 equidistantes, ramos levemente 3-angular, estriados, tomentosos, pubescentes ou vilosos. Folhas 5 -folioladas, estípula $4 \mathrm{~mm}$ compr., linear ou 
subulada; folíolos com face adaxial pubescente; frutos cordados, lóculos no ápice dilatados, vilosos, constrição ausente abaixo do lóculo, epicarpo viloso. É morfologicamente afim a S. trichomisca, diferindo nos tricomas pubérulos por toda a planta, folíolos laterais longo peciolulados e a não ocorrência em Minas Gerais para S. trichomisca.

9.12. Serjania paradoxa Radlk., Consp. Sect. Sp. Serjan. 6. 1874.

Prancha 4, fig. I.

Trepadeira, caule composto, 5 cilindros radialmente dispostos, ramos cilíndricos ou estriados, geralmente incano-glandulares ou pubescentes, lenticelas verrucosas. Folhas biternadas, pecíolo 2,6-8 cm compr., canaliculado, raque bicanaliculada ou marginada, incano-glandulares, estípulas 1-2 mm compr., subuladas, ciliadas; folíolos 1,8-7(12) x 1-3,5 cm, ovados ou elípticos, discolores, cartáceos, ápice agudo, mucronado, menos freqüente obtuso, arredondado e retuso sempre em 1 dos folíolos laterais, geralmente com glândula apical, margem inteira ou folíolos laterais geralmente com 1-2 dentes e com glândula apical, ciliada, as vezes com faixa translúcida, base atenuada no folíolo terminal, cuneada nos folíolos laterais, face adaxial pubérula ou glabra, incano nas nervuras, face abaxial hirsuta ou velutina, venação broquidódroma ou craspedódroma mista; domácias em bolsas. Tirso racemiforme, incano-glandular, 15-30 cm compr., cincinos 4-6-floros, brácteas e bractéolas 1-2 mm, subuladas ou lineares. Flores odoríferas, 4-6 mm compr., sépalas 4, oblongas, incano-glandulosas ou glabras; pétalas obovadas, glandulares, apêndice petaloide com crista emarginada ou inteira; lobos nectaríferos ovoides e orbiculares; flor 3 : estames 3-4 mm compr., filetes achatados, pilosos, pistilódio piloso; flor p: estaminódios 2-3 mm, ovário obovoide, glanduloso. Frutos castanhos a avermelhados, 1-2,5 × 2,5-3,2 cm, ovado-cordados, lóculos no ápice dilatados, glandulares, constrição ausente abaixo do lóculo, crista dorsal 2-4 
$\mathrm{mm}$ larg., alas glandulares, endocarpo pubérulo; sementes $5 \times 4 \mathrm{~mm}$, obovoides, inseridas na base dos lóculos.

Material examinado: Minas Gerais, Distrito de São José da Cachoeira, Santana do Pirapama, Serra do Cipó: Fazenda Inhame, Serra Mineira, 1855'S-4354'W, 20.III.1982, J.R. Pirani et al. CFSC 7958, fl. + (CTES, SPF); idem, 1855'S-4354'W, 24.III.1982, I. Cordeiro et al. CFSC 8196, fr. (CTES, SPF); idem, trilha da Senhorinha, 19000'22"S-4345'20"W, 19.Il.2007, V.C. Souza et al. 32227, bot. (ESA, SPFR); idem, V.C. Souza et al. 32853, fl. ô (BHCB, ESA); idem, V.C. Souza et al. 32785, fr. (ESA, SPFR); idem, 1900'22"S-4345'20"W, 19.Il.2007, V.C. Souza et al. 32533, fl. ô, fr. (BHCB, ESA, SPFR); idem, 1959'53.9"'S4346'09.7"W, 736m, 05.III.2009, K.F. Silva et al. 103, fl. , fr. (CTES, K, SPF, SPFR); idem, 1857'51.6"S-4346'53.0"W, 682m, 06.III.2009, K.F. Silva et al. 116, fr. (SPF, SPFR); idem trilha para cachoeira do Quartel, 1858'38.1"S-4346'33.4"W, 665m, 05.III.2009, K.F. Silva et al. 108, fl. +, fr. (CTES, K, SPF, SPFR); 1858'28.3"S-

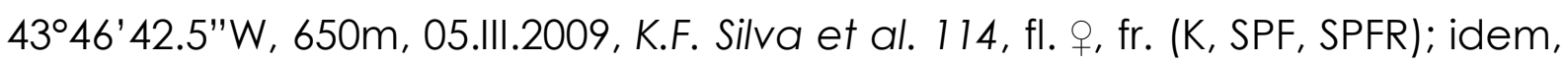
ca. 150m da acomodação para pesquisadores da Fazenda Toucan Cipó, 19000'17.5"S-4346'22.2"W, 685m, 05.Ill.2009, K.F. Silva et al. 100, fl. +, fr. (CTES, K, SPF, SPFR); idem, trilha sentido base da Serra (paredão rochoso), com início na estrada de terra próximo a Fazenda Toucan Cipó, 1859'58.7"S4346'19.2"W, 709m, 05.III.2009, K.F. Silva et al. 101, fr. (K, SPF, SPFR); idem, 1859'53.9"S-4346'09.7"W, 736m, 05.III.2009, K.F. Silva et al. 102, fr. (SPFR); idem, trilha da Captação da Fazenda Toucan Cipó, 1900'22"S-4345'20"W, 680m, 17.III.2007, V.C. Souza et al. 32550, fl. q (ESA); Santana do Riacho, Serra do Cipó, ao longo da rodovia, estrada da Usina, 10.XI.1980, I. Cordeiro et al. CFSC 6774, bot. (CTES, SP); idem, MG-010, trilha da pousada e restaurante Chapéu de Sol, 19¹8'37"S-4336'4.1"W, 1076m, 15.VI.2007, K.F. Silva et al. 26, fl. + (CTES, SPF, SPFR); UCAT, caminho do abrigo, 23.Il.1985, M.A. Lopes \& P.M. Andrade 10065, fr. (BHCB); estrada Santana do Riacho-Lapinha, 1908'17"S4341'41"W, 1090m, 05.III.1998, J.R. Pirani et al. 4213, fl. q (CTES, SPF); Jaboticatubas, PARNA Serra do Cipó, ca. $2 \mathrm{~km}$ da portaria principal, $19^{\circ} 21^{\prime} 31.3^{\prime \prime S}-43^{\circ} 36^{\prime} 14.8^{\prime \prime} \mathrm{W}, 819 \mathrm{~m}, 26 . \mathrm{VIII.2008,} \mathrm{K.F.} \mathrm{Silva} \mathrm{\&} \mathrm{R.F.} \mathrm{Oliani} 76$ (SPFR). 
Material adicional examinado: Brasil, Minas Gerais, II, 1869, Regnell III 449, fl. (B, sintipo, foto F, negativo 5570); Brasil, São Paulo, St. Hilaire, fl. (P, sintipo, foto F, negativo 36049).

Espécie endêmica do Brasil, ocorre nos estados da Bahia, Minas Gerais, São Paulo e Rio de Janeiro, nos Domínios da Caatinga, Cerrado e Mata Atlântica (Somner et al. 2010).Vegeta em mata semidecídua e cerrado (Ferrucci et al. 2009). Na Serra do Cipó foi encontrada no cerrado e em mata secundária; coletada com flor em fevereiro, março, junho e novembro e fruto em fevereiro e março.

Serjania paradoxa foi identificada principalmente pelo caule composto com 5 cilindros radialmente dispostos, ramos cilíndricos ou estriados, incano ou pubescentes, tricomas glandulares estipitados; folíolos com face adaxial pubérula ou glabra, face abaxial hirsuta, lanuginosa; domácias urceoladas; tirso 15-30 cm compr.; frutos ovado-cordados, lóculos no ápice dilatados, tricomas glandulares estipitados, constrição ausente abaixo do lóculo, crista dorsal 2-4 mm larg., epicarpo com tricomas glandulares estipitados. É morfologicamente afim a S. deflexa diferindo por esta possuir tricomas glandulares estipitados principalmente nos botões florais e de S. corrugata por esta possuir caule costado. E embora S. corrugata ocorra em Minas Gerais não foi encontrada na Serra do Cipó.

9.13. Serjania perulacea Radlk., Consp. Sect. Sp. Serjan. 11. 1874.

Trepadeira, caule composto, 1 cilindro central e 4-5(6) cilindros periféricos, menores que o central, sendo 2 complanados, ramos costados, triangular nos ramos mais velhos, glabros ou incanos, lactescentes. Folhas triternadas, pecíolo 3,5 - 8,5 cm compr., canaliculado, raque bicanaliculada, incano-pilosos, estípula $1 \mathrm{~mm}$ compr., triangular; folíolos (2)4-11,5 x (0,9)2-7,5 cm, ovados ou elípticos, rômbicos nos folíolos terminais, discolores, cartáceos, ciliados, ápice agudo, obtuso ou acuminado, mucronado, com glândula, margem denteada no 1/2 superior, glândula subapical, base decurrente no folíolo terminal, obtusa, cuneada ou levemente assimétrica nos folíolos 
laterais, face adaxial glabra, pilosa na região das nervuras, face abaxial glabra, venação craspedódroma mista; domácias barbadas. Tirso racemiforme, $10 \mathrm{~cm}$ compr., cincinos 3-4-floros, pubescentes, brácteas e bractéolas $1 \mathrm{~mm}$, triangulares. Flores $5 \mathrm{~mm}$ compr., sépalas 5, ovadas, coriáceas, glabras ou tomentosas; pétalas espatuladas, glandulares, apêndice petaloide de igual tamanho as pétalas, crista erosa; lobos nectaríferos ovoides, menores orbiculares; flor t3: estames 4-5 mm compr., filetes achatados, pubescentes, pistilódio glabro; flor o: estaminódios 2-3 mm compr., ovário trígono, glabro ou viloso. Fruto $2 \times 1,5 \mathrm{~cm}$, ovado-cordado, lóculos no ápice dilatados, velutinos, constrição ausente abaixo do lóculo, crista dorsal $2 \mathrm{~mm}$ larg., alas pubescentes, endocarpo lanoso; sementes $4 \times 3$ $\mathrm{mm}$, elipsoides, inseridas na base dos lóculos.

Material examinado: Minas Gerais, Distrito de São José da Cachoeira (Inhame), Santana de Pirapama, Rio Cipó, 1858'28.3"S-4346'42.5"W, 650m, 06.III.2009, K.F. Silva et al. 110 (SPFR); Cardeal Mota, PARNA Serra do Cipó, Km 97 da rodovia MG 0-10, portaria do Retiro (IBAMA), início trilha Vale do Ribeirão Bocaína, 19²0'33.6"S-4336'19.2"W, 823m, 19.Il.2010, K.F. Silva \& T.P. Martins 153 (SPFR).

Material adicional examinado: São Paulo, Ribeirão Preto, Campus da USP localizada no interior da mata em frente a entomologia, 13.VII.2010, J.P. Castro 239 (SPFR), Argentina, Misiones, Dep. Candelaria, 22.VIII.1987, A.Schinini 25464, fl. ô (CTES, SPF).

Ocorre na América do Sul, na Bolívia, Argentina, Paraguai e Brasil (Ferrucci 1993, Ferrucci et al. 2009), nos estados do Mato Grosso, Goiás, Mato Grosso do Sul, Minas Gerais e São Paulo, nos Domínios do Cerrado, Mata Atlântica e Pantanal (Somner et al. 2010). Na Serra do Cipó foi encontrada principalmente em área de mata ciliar; coletada apenas em estado vegetativo.

Serjania perulacea foi identificada principalmente pelo caule composto com 1 cilindro central e 4-5(6) cilindros periféricos, menores que o central, ramos costados, triangular nos ramos mais velhos, lactescentes; 
folhas triternadas; tirso $10 \mathrm{~cm}$ compr.; fruto ovado-cordado, lóculos no ápice dilatados, velutinos e constrição ausente abaixo do lóculo. Segundo Ferrucci com. pess. é comum nas espécies do Brasil e da Bolívia a presença de folíolos biternados, embora não encontrado nas espécies da Serra do Cipó. É morfologicamente afim a S. lethalis, diferindo principalmente nos cilindros periféricos não complanados e as folhas biternadas de S. lethalis.

9.14. Serjania pinnatifolia Radlk., Consp. Sect. Sp. Serjan. 10. 1874.

Prancha 4, fig. J.

Trepadeira, caule composto, 1 cilindro central e 8 cilindros periféricos iguais ao central, ramos 8-10 costados, tomentosos ou pubescentes, ferrugíneos, lactescentes, lenticelas lineares e verrucosas. Folhas 5-folioladas, pecíolo 1,4 - 7 cm compr., canaliculado, raque bicanaliculada, pubescentes ou tomentosos, estípula 1-3 mm compr., triangular; folíolos 3-8,5 x 1,9-5,4 cm, ovados, obovados ou oblongos, discolores, cartáceos, ápice agudo e mucronado, com glândula, margem denteada $2 / 3$ superior, dentes com glândula subapical, base decurrente no folíolo terminal, obtusa nos folíolos laterais, face adaxial pilosa ou pubérula, face abaxial pubescente, principalmente na região das nervuras, venação craspedódroma; domácias ausentes. Tirso racemiforme, 10-17 cm compr., cincinos 5-floros, tomentosos, brácteas e bractéolas 1-2 mm, subuladas. Flores 3-6 mm compr., sépalas 5, ovadas, coriáceas, pubescentes ou glabras; pétalas espatuladas, glandulosas, apêndice petaloide com crista retusa; lobos nectaríferos ovoides, menores orbiculares; flor 3 : estames $3-5 \mathrm{~mm}$ compr., filetes achatados, pilosos, pistilódio glabro; flor o: estaminódios 3-4 mm compr., ovário obovoide, glabro. Fruto róseo, 2,7-3,3 x 2,1-2,6 cm, cordadoretangular, lóculos no ápice dilatados, vilosos, constrição ausente abaixo do lóculo, crista dorsal ausente, alas pubérulas, endocarpo viloso; sementes 2-7 x1-7 mm, elipsoides, inseridas na metade dos lóculos. 
Material examinado: Minas Gerais, Santana do Riacho, Cardeal Mota,

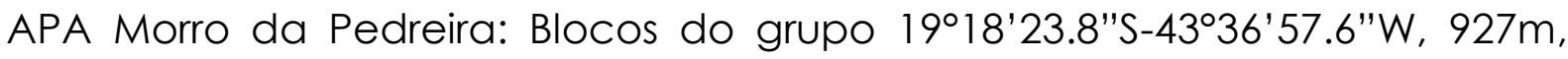
22.V.2007, L.M. Borges et al. 158, fr. (SPF, SPFR), idem, Grupo 3, 19¹8'27"S43036'50"W, 900m, 05.Ill.2002, J.R. Pirani et al. 4992, fl. क (SPF, SPFR); idem, 21.IV.1990, A.M.C. Pimenta et al. s/nº, fr. (BHCB); idem, UCAT, 14.IV.1985, P.M. Andrade \& M.A. Lopes $s / n^{\circ}$, fl. o (BHCB); Jaboticatubas, na orla da rodovia MG-010, de Conceição do Mato Dentro para Lagoa Santa, $13 \mathrm{~km}$ antes de Lagoa Santa, 600m, 21.VIII.1986, P. Acevedo-Rodríguez et al. 1509, fl. \& (RB).

Material adicional examinado: São Paulo, Ribeirão Preto, Estação Ecológica de Ribeirão Preto, $21^{\circ} 13 S-47^{\circ} 50^{\prime}$ W, 518m, 08.VI.2006, K.F. Silva 212 , fl. ô (SPFR); Brasil, Minas Gerais, Lagoa Santa, Warming (M, sintipo, foto F, negativo 5976).

Espécie endêmica do Brasil, ocorre nos estados da Bahia, Minas Gerais e São Paulo, nos Domínios do Cerrado e Mata Atlântica (Somner et al. 2010).Vegeta mata mesófila semidecídua, cerradão e mata ciliar (Ferrucci et al. 2010). Na Serra do Cipó foi encontrada em afloramento rochoso, na região da APA Morro da Pedreira e em mata degradada em borda de estrada; coletada com flor em março, abril e agosto e fruto em abril e maio.

Serjania pinnatifolia foi identificada principalmente pelo caule composto com 1 cilindro central e 8 cilindros periféricos iguais ao central, ramos 8-10 costados, tomentosos ou pubescentes, lactescentes; folhas 5folioladas; fruto cordado-retangular, lóculos no ápice dilatados, viloso, constrição ausente abaixo do lóculo e crista dorsal ausente. É morfologicamente afim a S. clematidea diferindo principalmente nas folhas biternadas e na não ocorrência de S. clematidea em Minas Gerais.

9.15. Serjania purpurascens Radlk., Consp. Sect. Sp. Serjan.: 16. 1874.

Prancha 4, fig. K-M.

Trepadeira, caule composto, 1 cilindro central e 8 cilindros periféricos, menores que o central, ramos cilíndricos ou levemente sulcados, 
pubescentes, lactescentes, lenticelas verrucosas. Folhas biternadas; pecíolo 2-4(8) cm compr., e raque canaliculados ou bicanaliculados, incanos ou pubescentes, estípula $1 \mathrm{~mm}$ compr., triangular; folíolos (1,5)3-11(13) x 1,2-6 $\mathrm{cm}$, laterais menores e desiguais, 1 lateral sempre menor, elípticos, discolores, cartáceos, ápice agudo ou obtuso, mucronado, com glândula, margem denteada no $2 / 3$ superior, ciliada, glândula apical ou subapical, base decurrente no folíolo terminal, cuneada nos folíolos laterais, face adaxial brilhante, glabra, pilosa ou pubescente na região das nervuras, pontos translúcidos, face abaxial púrpuro-castanha, glabra ou pilosa, utrículos laticíferos, venação craspedódroma mista; domácias barbadas. Tirso racemiforme, 3,5-22 cm compr., cincinos 4-8-floros, pubescentes, brácteas e bractéolas $1 \mathrm{~mm}$, lineares. Flores $3 \mathrm{~mm}$ compr., sépalas 5, ovadas, cuculadas, tomentosas ou glabras; pétalas espatuladas, glandulares, apêndice petaloide com crista erosa ou inteira; lobos nectaríferos ovoides, menores orbiculares; flor 3 : estames 3-4 mm compr., filetes achatados, pubescentes, pistilódio pubérulo; flor +: estaminódios $3 \mathrm{~mm}$ compr., ovário elipsoide, glabro. Fruto marrom a levemente avermelhado, 2-2,7 × 2,5 cm, ovado-cordado, lóculos no ápice dilatados, glabros, constrição ausente abaixo do lóculo, crista dorsal 0,5 mm larg., alas glabras, endocarpo glabro; sementes $3 \times 1 \mathrm{~mm}$, elipsoides, inseridas na base dos lóculos.

Material examinado: Minas Gerais, Santana do Riacho, Serra do Cipó: Km 120 da rodovia MG 0-10, córrego Três Pontinhas, 19¹6'05.2"S4332'48.8"W, 1229m, 16.VI.2007, K.F. Silva et al. 35 (SPFR); idem, Km 119 da rodovia MG 0-10, entre a estátua do Juquinha e a trilha para a cachoeira da

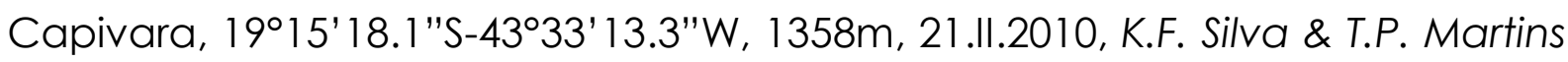
163, fl. ô, o (CTES, SPF, SPFR); idem, km 131 (atual 119), 30.III.1980, l. Cordeiro et al. CFSC 6064, fl. +, fr. (CTES, RB, SP, SPF); idem, km 116 (atual 115), 19.IV.1981, A. Furlan et al. CFSC 7227, fr. (SPF, SPFR); idem, Córrego Três Pontinhas, 25.IV.1994, J.R. Pirani et al. CFSC 12944, fl. o, fr. (CTES, NY, SPF); Distrito de Três Barras, Serra do Cipó, cachoeira Três Barras, $1^{\circ} 05^{\prime} \mathrm{S}-43^{\circ} 29^{\prime} \mathrm{W}, 716 \mathrm{~m}$, 15.VIII.2009, K.F. Silva \& R.F. Oliani 135 (SPFR); idem, K.F. Silva \& R.F. Oliani 136, 
fr. (CTES, SPF, SPFR) Cardeal Mota, PARNA Serra do Cipó, Km 97 da rodovia MG-010 (Lagoa Santa-Conceição do Mato Dentro), trilha do Vale do Ribeirão Bocaína, 19²0'39.8"S-4335'22.7"W, 809m, 19.II.2010, K.F. Silva \& T.P. Martins 151 (SPFR); Itambé do Mato Dentro, Distrito de Santana do Rio Preto (Cabeça de Boi), mata do Cachoeirão em frente a Serra das Posses, 19²5'55.7"S-4326'05.7"W, 1034m, 28.V.2010, K.F. Silva et al. 183 (SPFR); Serra do Cipó, estrada para Diamantina, 1500m, 28.IV.1973, P.I.S. Braga \& M.F. Osnir 2664, fl. ô (RB).

Material adicional examinado: Brasil, Rio de Janeiro, 1832, Sello, fl. (B, sintipo, foto F, negativo 5576).

Espécie endêmica do Brasil, ocorre nos estados de Minas Gerais e Rio de Janeiro, nos Domínios do Cerrado e Mata Atlântica (Somner et al. 2010). Na Serra do Cipó foi encontrada em mata ciliar e em Mata Estacional Semidecídua; coletada com flor em fevereiro a abril e fruto em março, abril e agosto.

Serjania purpurascens foi identificada principalmente pelo caule composto com 1 cilindro central e 8 cilindros periféricos, menores que o central, ramos cilíndricos ou levemente sulcados, lactescentes; folhas biternadas, folíolos com margem denteada no $2 / 3$ superior e face abaxial púrpuro-castanha; fruto ovado-cordado, lóculos no ápice dilatados, constrição ausente abaixo do lóculo. É morfologicamente afim a S. nigricans diferindo na margem crenada ou serreada-denteado do folíolo que essa possui. S. nigricans embora ocorra em Minas Gerais não foi encontrada na Serra do Cipó.

9.16. Serjania reticulata Cambess., Fl. Bras. Merid. (quarto ed.) 1: 359. 1827.

Prancha 4, fig. P-Q.

Trepadeira, caule simples, ramos 5-6 costados, geniculados, às vezes fistulosos, lactescentes, glabros, incanos ou pubescentes, lenticelas lineares ou verrucosas. Folhas biternadas, pecíolo $1-6,5 \mathrm{~cm}$ compr., canaliculado, 
raque bicanaliculada, glabros ou incanos, estípula 1,5 $\mathrm{mm}$ compr., triangular; folíolos 1,5-8,5 x $(0,8) 1,5-4 \mathrm{~cm}$, laterais bem menores que o terminal, ovados ou oblongos, discolores, cartáceos, ápice agudo, arredondado ou acuminado, mucronado, geralmente com glândula apical, margem repando-denteada, 1-9 dentes no 1/3 superior, geralmente com glândula, linha cartilaginosa, base atenuada, geralmente decurrente no folíolo terminal, face adaxial glabra, face abaxial glabra a pubescente, pilosa nas nervuras, com coloração avermelhada ou pálida, venação craspedódroma mista, domácias barbadas geralmente na base ou ausentes. Tirso racemiforme, $5-25 \mathrm{~cm}$ compr., cincinos 6-floros, incanos ou pubérulos, brácteas e bractéolas $1 \mathrm{~mm}$, triangulares, glandulares. Flores $5 \mathrm{~mm}$ compr., sépalas 5, cuculadas, obovadas, pubérulas ou pubescentes; pétalas glabras, glandulosas, apêndice petaloide com crista bífida; lobos nectaríferos ovoides, menores orbiculares; flor 3 : estames $3-4 \mathrm{~mm}$ compr., filetes achatados, pilosos, pistilódio piloso; flor q: estaminódios 2-3 mm, ovário trígono-obovado, glandular. Fruto vermelho, 1,1-1,7 x 0,8-1,7 cm, ovadocordado, lóculos no ápice dilatados, glabros, lustrosos, constrição ausente abaixo do lóculo, crista dorsal 0-2 mm larg., alas glabras, endocarpo viloso; sementes 2-4 x 1-3 mm, obovoides, inseridas na base dos lóculos.

Material examinado: Minas Gerais, Santana do Riacho, Serra do Cipó:ao longo da rodovia MG-010, 19¹6'38.8"S-4332'56.9"W, 1164m, 16.VI.2007, K.F. Silva et al. 31, fr. (BHCB, CTES, MBM, RB, SPF, SPFR); idem, 19018'37"S-4336'4.1"W, 1076m, 16.VI.2007, K.F. Silva et al. 29 (SPFR); estrada para a cachoeira da Caverna, 19015'09.9"S-43³5'07.1"W, 1062m, 23.IX.2007, K.F. Silva et al. 58, fr. (CTES, SPF, SPFR); idem, K.F. Silva et al. 59, fr. (CTES, SPF, SPFR) idem, Km 114 (atual 109) ao longo da rodovia Lagoa Santa-Conceição do Mato Dentro-Diamantina, 21.V.1974, J. Semir \& A.M. Giulietti 5043, fl. §., + , fr. (SP), Jaboticatubas, Km 126 (atual 115) ao longo da rodovia Lagoa SantaConceição do Mato Dentro-Diamantina, 1200m, 17.IV.1972, A.B. Joly et al. 1959, fl. ô (SP); idem, Km 114 (atual 109) ao longo da rodovia Lagoa SantaConceição do Mato Dentro-Diamantina, 21.V.1974, J. Semir \& A.M. Giulietti 
5043, fl. §ิ, 9, fr. (SP); idem, MG-010 Km 93, borda da estrada do Córrego João

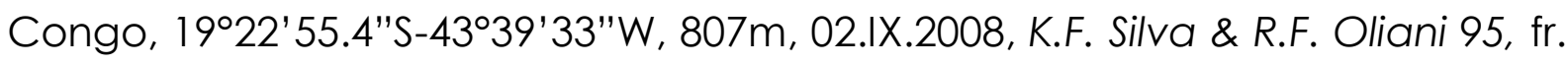
(CTES, SPF, SPFR).

Material adicional examinado: São Paulo, Mogi Guaçu, Fazenda Campininha, 19.IV.1995, A.R. Silva s/nº, fl. ô, +, fr. (UEC); Brasil, Minas Gerais, St. Hilaire, fl. (P, sintipo, foto F, negativo 36050).

Na América do Sul ocorre na Bolívia, Argentina e Brasil (Ferrucci et al. 2009), nos estados do Mato Grosso, Goiás, Minas Gerais, São Paulo, Rio de Janeiro, Paraná e Santa Catarina, nos Domínios do Cerrado, Mata Atlântica e Pantanal (Somner et al. 2010). Vegeta o cerrado, cerradão, campo rupestre, mata mesófila e mata atlântica (Ferrucci et al. 2009). Na Serra do Cipó foi encontrada no cerrado e em mata ciliar; coletada com flor em abril e maio e fruto em maio, junho e setembro.

Serjania reticulata foi identificada principalmente pelo caule simples, ramos 5-6 costados, geralmente geniculados, às vezes fistulosos, lactescentes; folíolos com margem repando-denteada, 1-9 dentes no 1/3 superior e linha cartilaginosa, face abaxial com coloração avermelhada ou pálida; fruto ovado-cordado, lóculos no ápice dilatados, glabros, lustrosos, constrição ausente abaixo do lóculo, alas glabras, geralmente avermelhadas.

9.17. Serjania tripleuria Ferrucci Bonplandia (Corrientes) 5(21-29): 246. 1983.

Trepadeira jovem, caule composto, 1 cilindro central e 3-4 cilindros periféricos, quando 3 equidistantes e quando 4, 2 cilindros estão pareados, ramos 3-angulares, pubérulos ou pubescentes. Folhas 5-folioladas, pecíolo 7,5-8,5 cm compr. canaliculado, raque bicanaliculada, pubescentes, estípula $1 \mathrm{~mm}$ compr., triangular; folíolos 4,5-10 x 3-5,5 cm, laterais menores que o terminal, elípticos ou obovados, terminal rômbico, discolores, margem ciliada, cartáceos, ápice agudo, com glândula, margem denteada, 4-5 dentes no 1/2 superior, dentes com glândula subapical, base cuneada ou 
atenuada, face adaxial pubérula, face abaxial pubescente, venação craspedódroma mista; domácias barbadas. Tirso (não visualizado, retirado de Ferrucci 1983): axilar, densamente coberto de tricomas curtos, amarelos, 61-109 mm compr., costas pouco marcadas, cincinos pedunculados, glabros a pubérulos; brácteas triangulares, $1 \mathrm{~mm}$ compr., glabriúsculas, ciliadas. Flor (não visualizada, retirado de Ferrucci 1983): estaminada $6 \mathrm{~mm}$ compr., sépalas pubescentes, sublanuginosas e lanuginosas; pétalas glandulosas, obovadas, crista da escama das pétalas anteriores ovada com ápice eroso, apêndice deflexo linguiforme, viloso, tanto nas escamas superiores como nas laterais; nectários florais 4, anteriores ovoides, pubérulos, laterais elípticos, glabros. Androginóforo glabro. Estames $6 \mathrm{~mm}$ compr., filetes pubescentes, anteras glabras. Pistilódio glabro. Flor hermafrodita $7 \mathrm{~mm}$ compr. Estaminódios 3,5 mm compr., ovário pubérulo sobre a veia dorsal de cada carpelo, estilete 1,5-2 mm compr., pouco mais comprido que os ramos do estigma. Fruto (não visualizado, retirado de Ferrucci 1983): 25 × 23 mm, porção seminífera globosa, constrição notável abaixo da mesma, epicarpo glabro a exceção de escassos tricomas glandulares curtos sobre os lóculos, endocarpo glabro. Sementes subtranversa-obovoideas, 6,5 ×5,5 mm, inserida abaixo da metade do lóculo.

Material examinado: Minas Gerais, Santana do Riacho, Serra do Cipó: Km 104 da rodovia MG-010 (Lagoa Santa-Conceição do Mato Dentro), APA Morro da Pedreira (2 grupo), 19¹8'38.2"S-4336'45.9"'W, 945m, 31.V.2010, K.F. Silva et al. 203 (CTES, SPFR).

Ocorre no Sul da Bolívia (Santa Cruz), noroeste da Argentina (Salta e Jujuy) e extremo norte do Paraguai oriental (Ferrucci 1991). No Brasil, nos estados do Mato Grosso do Sul e São Paulo, nos Domínios do Pantanal e Mata Atlântica (Somner et al. 2010). Na Serra do Cipó parece restrita a APA Morro da Pedreira; coletada apenas em estado vegetativo.

Serjania tripleuria foi identificada principalmente pelo caule composto, 1 cilindro central e 3-4 cilindros periféricos, quando 3 equidistantes e quando 4, 2 cilindros estão pareados, 3-angulares; folhas 5-folioladas, margem dos 
folíolos denteada, 4-5 dentes no 1/2 superior. É morfologicamente afim a Serjania caracasana, cujas diferenças foram citadas anteriormente.

9.18. Serjania tristis Radlk. Consp. Sect. Sp. Serjan. 14. 1874.

Prancha 4, fig. N-O.

Trepadeira, caule simples, ramos 5-6-alados, fistulosos, hirtopubescentes ou incano-pubérulos, alas suberosas, lenticelas lineares ou verrucosas. Folhas biternadas, pecíolo $2-7 \mathrm{~cm}$ compr., canaliculado ou bicanaliculado, raque marginada ou alada, pubescentes ou hirsutos, estípula $1 \mathrm{~mm}$ compr., ovada; peciólulo alado; folíolos 1-10 x 1-5,5 cm, laterais ovados, terminal oblongo, rômbico, discolores, cartáceos, ápice agudo, obtuso, acuminado, mucronado, margem repando-denteada no 1/2 superior, dentes com glândula apical, base atenuada no folíolo terminal, cuneada nos folíolos laterais, face adaxial pilosa, nervuras pubescentes, pontos translúcidos, face abaxial pilosa, nervuras hirtas, venação craspedódroma mista, término das nervuras entre os dentes ciliadas; domácias foveoladas, barbadas ou ausentes. Tirso racemiforme, $15 \mathrm{~cm}$ compr., cincinos (2)3-4-floros, pubescentes, brácteas e bractéolas 1-1,5 mm, triangulares, ciliadas. Flores 4-5 mm compr., sépalas 5, cuculadas, ovadas, pubescentes, ciliadas; pétalas ungüiculadas, glandulosas, apêndice petaloide com crista erosa; lobos nectaríferos ovoides, menores orbiculares; flor $\hat{o}$ (não visualizada, retirado de Ferrucci 1991): estames 3-3,5 mm compr., filetes pubérulos na base, pistilódio glabro; flor q: estaminódios $3 \mathrm{~mm}$, ovário obovoide, pubescente. Fruto 1,5-1,8 x 1,2-1,4 cm, ovado, lóculos no ápice dilatados, constrição ausente, pubescentes, crista dorsal $1 \mathrm{~mm}$ larg., alas pubérulas, nervuras proeminentes, endocarpo viloso; sementes $3 \mathrm{~mm}$, obovoides, inseridas na base dos lóculos.

Material examinado: Minas Gerais, Santana do Riacho, Serra do Cipó:

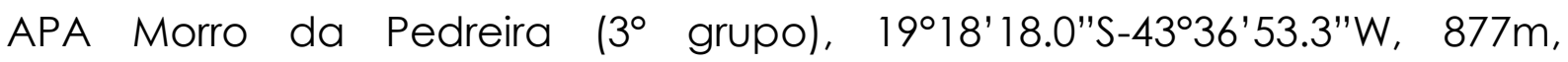


31.VIII.2008, K.F. Silva \& R.F. Oliani 167 (SPFR); idem, (2 grupo), 19¹8'36.7"S4336'44.1 "W, 976m, 31.V.2010, K.F. Silva et al. 204 (CTES, SPFR).

Material adicional examinado: Paraná: Jataizinho, 24.IV.2003, J.D. Urdampilleta 157, fr. (CTES, HUEM); idem, São Pedro do Paraná, Ribeirão São Pedro, 27.III.2004, M.C. de Souza 1676, fl. o (CTES, HUEM).

Espécie endêmica do Brasil, ocorre nos estados de Minas Gerais, São Paulo e Paraná, no Domínio da Mata Atlântica (Somner et al. 2010). Vegeta mata de encosta (Ferrucci et al. 2009). Na Serra do Cipó parece restrita a APA Morro da Pedreira; coletada apenas em estado vegetativo.

Serjania tristis foi identificada principalmente pelo caule simples, ramos 5-6-alados, fistulosos, alas suberosas; folhas com raque marginada ou alada, peciólulo alado; face adaxial com pontos translúcidos, término das nervuras entre os dentes ciliada; fruto ovado, lóculos no ápice dilatados, constrição ausente, alas com nervuras proeminentes. É morfologicamente afim a S. truncata, diferindo pelos folíolos obtuso-denteados; fruto cordado-ovado com ápice truncado e glabro presentes em S. truncata. Segundo (Somner et al. 2010), Serjania truncata não ocorre em Minas Gerais.

\section{Toulicia Aubl.}

Árvores ou arbustos, monoicos; ramos cilíndricos, estriados, glabros ou pubérulos, lenticelados. Folhas paripinadas, alternas; folíolos curtopeciolulados, alternos ou subopostos, cartáceos, concolores, margem geralmente inteira, domácias ausentes. Tirso duplo, axilar ou terminal; brácteas e bractéolas presentes, persistentes. Flores brancas, cálice 5-mero, dialissépalo, não persistentes no fruto; corola 4-mera, dialipétalas, pétalas ungüiculadas, apêndice petaloide com ápice bipartido, disco nectarífero unilateral, pubescente; androceu com 8 estames, filetes pubescentes, anteras glabras, pistilódio presente; gineceu: 3-carpelar, 3-locular, 1 óvulo por carpelo, estilete filiforme, estigma 3 -fido ou com os ramos concrescidos. Fruto 
esquizocárpico, 3-mericarpos samaroides, castanho-claros, com porção seminífera na parte distal do mericarpo; sementes lenticulares, tegumento crustáceo, liso, embrião curvo, cotilédone externo curvo, interno plicado.

Gênero sul-americano com aproximadamente 14 espécies, no Brasil ocorrem 6 espécies endêmicas, encontrada nos Domínios da Amazônia, Cerrado e Mata Atlântica (Somner et al. 2010). Na Serra do Cipó ocorre 1 espécie.

10.1. Toulicia laevigata Radlk., Sitzungsber. Math.-Phys. Cl. Königl. Bayer. Akad. Wiss. München 8: 372. 1878.

Prancha 4, fig. R-S.

Árvores 5-16m alt., ramos muito ramificados; lenticelas verrucosas. Folhas: pecíolo cilíndrico, 3,5-5,5 cm compr., raque cilíndrica, ambos pubérulos, peciólulo 2-3 mm, bicanaliculado; folíolos 7-10 pares, 3-9 x 1-2 cm, elípticos ou lanceolados, assimétricos, cartáceos, ápice acuminado ou mucronado, margem denteada no 1/3 superior, base oblíqua; face adaxial glabra, nervura média impressa, face abaxial com poucos tricomas bem esparsos, pilosa nas nervuras, nervação craspedódroma mista. Tirso $12-15 \mathrm{~cm}$ compr., pubescente, cincinos 2-3-floros; brácteas e bractéolas 1-2 mm compr., subuladas. Flores zigomorfas, $3 \mathrm{~mm}$ compr., odoríferas, curto pediceladas, sépalas 2-3 x 1,5-2 mm, ovadas, coriáceas, ciliadas, corola 5mera, pétalas $3 \times 1 \mathrm{~mm}$, espatuladas, ciliadas, apêndice petaloide viloso, disco nectarífero lobado; flor 3 : estames $3-4 \mathrm{~mm}$ compr., pistilódio pubescente; + (não visualizada, retirado de Radlkofer 1892): ovário trígonopiriforme, pubescente, amarelado, estilete glabro. Fruto $3,5 \times 1,5 \mathrm{~cm}$, elípticoretangular, retuso, subglabro.

Material examinado: Minas Gerais: Serra do Cipó, MG 232, estrada de

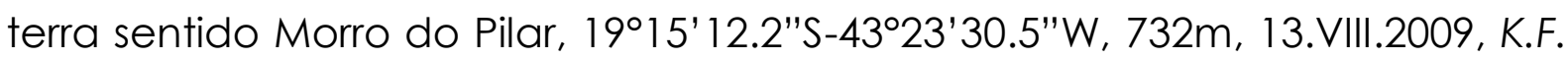
Silva \& R.F. Oliani 121, fl. ô (CTES, SPF, SPFR); Itambé do Mato Dentro, Distrito de Santana do Rio Preto (Cabeça de Boi), APA do Parque Nacional da Serra 
do Cipó, Terras do José Agostinho, 19²3'46.9"S-43²4'07.4"W, 15.XII.2007, M.F. Santos \& L.M. Borges 456 (SPF).

Material adicional examinado: Brasil, Rio de Janeiro, Tijuca/Corcovado, 1878, Glaziou 9370/9371, fl., fr. (B, sintipo, foto F, negativo 5665).

Espécie endêmica do Brasil ocorre nos estados de Minas Gerais, Espírito Santo e Rio de Janeiro. Na Serra do Cipó foi encontrada na Mata Ciliar do Rio Preto de Cima e na porção leste em Floresta Estacional Semidecídua; coletada com flores em agosto.

Toulicia laevigata foi identificada principalmente pelos folíolos 7-10 pares, elípticos ou lanceolados, assimétricos, ápice acuminado ou mucronado, margem denteada no $1 / 3$ superior, base assimétrica; fruto elíptico-retangular e retuso. É morfologicamente afim a Toulicia stans diferindo principalmente pelos caracteres supracitados, pois $T$. stans possui folíolos com margem serreada, nervação notável e inflorescência acima de $15 \mathrm{~cm}$ compr. 


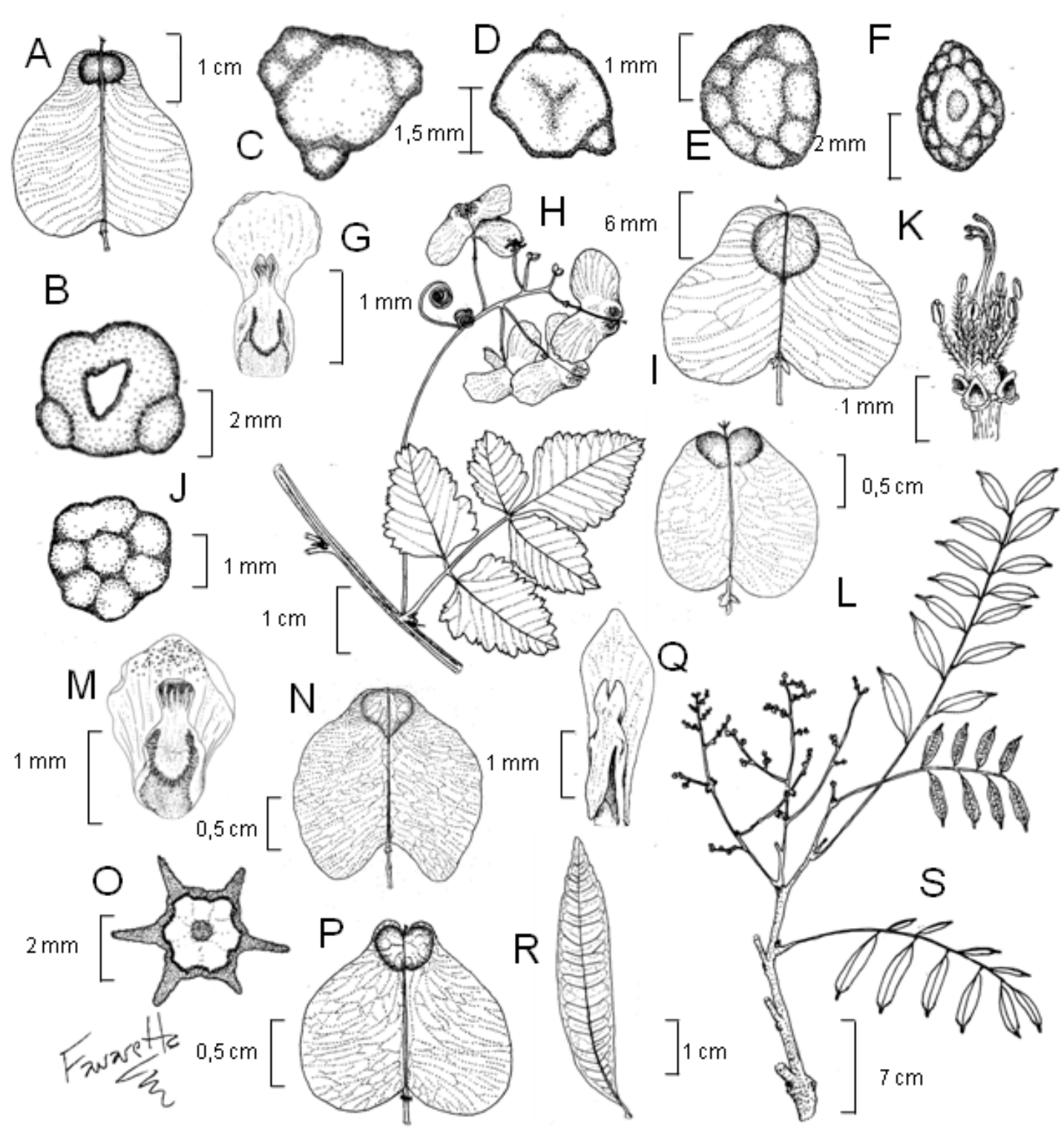

Prancha 4. A-B. Serjania erecta, A. fruto; B. caule, corte transversal. C. Serjania lethalis, caule, corte transversa1. D. Serjania marginata, caule, corte transversal. E. Serjania multiflora, caule, corte transversal. F. Serjania noxia, caule, corte transversal. G. Serjania obtugidentata, apêndice petalóide. H. Serjania paludosa, ram o florífero. I. Serjania paradoxa, fruto. J. Serjania pirmatifolia, caule, corte transversa1. K-M. Serjania pupurascens, K. flor feminina, mostrando os lobos nectaríferos, as sépalas e pétalas foram retiradas. L. fruto, M. apêndice petalóide. N-O. Serjania tristis, N. fruto, O. caule, corte transversal. P-Q. Serjania reticulata, P. fruto, Q. apêndice petalóide. R-S. Toulicia laevigata, R. foliolo, S. ram o florífero. (A.B, Silva et al. 198; C, Silva 60; D, Oliveira 4066; E, Leitão Filho et al. 1670-A; F, Silva et al. 129; G, Hentique et al. CFSC 6629; H, Silva et al. 107; I, Silva et al. 103 ; J. Pirani et al. 4992; K-M, Pirani et al. 12944; N-O, Silva et al. 204 (caule), Urdam pilleta 157 (fr.); P-Q, Silva et al. 31 (fr), Semir \& Giulietti 5043; R-S, Silva \& Oliani 12I). Ilustrações: Favaretto. 


\section{Referências}

ACEVEDO-RODRIGUEZ, P. 1987. Two new species of Serjania (Sapindaceae), from Brazil. Brittonia, 39: 348-353.

ACEVEDO-RODRIGUEZ, P. 1993. Systematics of Serjania (Sapindaceae), part I: a revision of Serjania sect. Platycoccus. Memoirs of the New York Botanical Garden 67: 93p.

ACEVEDO-RODRIGUEZ, P.; Van Welzen, P.C.; Adema, F. \& Van der Ham, R.W.J.M. 2011. Sapindaceae. In: The families and Genera of Vascular Plants - Flowering Plants Eudicots: Sapindales, Cucurbitales, Myrtaceae (K. Kubitzki, Ed.). Springer-Verlag Berlin Heidelberg, v. 10, 356-406p.

APG (ANGIOSPERM PHYLOGENY GROUP) II. 2003. An update of the Angiosperm Phylogeny Group classification for the orders and families of flowering plants: APG II. Bot. J. Linnean Soc. 141: 399-436.

APG (ANGIOSPERM PHYLOGENY GROUP) III. 2009. An update of the Angiosperm Phylogeny Group classification for the orders and families of flowering plants: APG III. Bot. J. Linnean Soc. 161: 105-121.

BARKLEY, F.A. 1957. Sapindaceae of Southern South America. Lilloa. 28: 111 179.

BUERKI, S.; Forest, F.; Acevedo-Rodríguez, P.; Callmander, M.W.; Nylander, J.A.A.; Harrington, M.; Sanmartín, l.; Küpfer, P. \& Alvarez, N. 2009. Plastid and nuclear markers reveal intricate relationships at subfamilial and tribal levels in the soapberry family (Sapindaceae). Mol. Phylogenetics and Evol. 51 (2):238-258.

BUERKI, S.; Lowry II, P.P.; Alvarez, N.; Razafimandimbison, S.G.; Küpfer, P. \& Callmander, M.W. 2010. Phylogeny and circumscription of Sapindaceae revisited: molecular sequence data, morphology and biogeography support recognition of a new family, Xanthoceraceae. Plant Ecology and Evolution: 1-12.

COELHO, R.L.G. 2008. Estudos taxonômicos em Matayba Aubl. Sect. Matayba (Sapindaceae). Dissertação (Mestrado) - Universidade Estadual de Campinas. Instituto de Biologia. 170 p.

CROAT, T.B. 1976. Flora of Panama (Family 108. Sapindaceae). Annais Missouri Botanical Garden, 63(3): 419-540.

FERRUCCl, M.S. 1983. Novedades em Serjania (Sapindaceae). Bonplandia, 27(5): 243-256. 
FERRUCCI, M.S. 1991. Sapindaceae. In: Spichiger \& Ramella (Eds.), Flora del Paraguay. Conservatoire et Jardin Botaniques de la Ville de Genéve \& Luis, Missouri Botanical Garden, 16: 1-144.

FERRUCCI, M.S. 1993. Una nueva especie y una nueva combinacion en Cardiospermum (Sapindaceae). Bonplandia, 6(4): 245-259.

FERRUCCI, M.S. 2000. Revisión taxonómmica de los géneros Cardiospermum y Urvillea para el Neotrópico (Sapindaceae). Ph.D. dissertation, Universidad Nacional de Cordoba. Argentina, 262p.

FERRUCCl, M.S. 2003. Flora de Grão-Mogol, Minas Gerais: Sapindaceae. Bol. Bot. Univ. São Paulo 24: 79-86.

FERRUCCl, M.S.; Somner, G.V. \& Rosa, M.M.T. 2009. Sapindaceae. (Coord. Somner, G.V.) In: Flora Fanerogâmica do Estado de São Paulo (Coords. Wanderley, M.G.L.; Shepherd, G.J.; Melhem, T.S.; Giulietti, A.M. \& Martins, S.E.). Secretaria do Meio Ambiente. Instituto de Botânica. FAPESP. São Paulo. v.6. 196-255p.

FERRUCCl, M.S.; Somner, G.V. \& Coelho, R.L.G. 2009b. Sapindaceae. (Coord. Somner, G.V.) In: Flora Fanerogâmica do Estado de São Paulo (Coords. Wanderley, M.G.L.; Shepherd, G.J.; Melhem, T.S.; Giulietti, A.M. \& Martins, S.E.). Secretaria do Meio Ambiente. Instituto de Botânica. FAPESP. São Paulo. v.6. 196-255p.

GADEK, P.A. ; Fernando, E.S. ; Quinn, C.J. ; Hoot, S.B. ; Terrazas, T. ; Sheahan, M.C. \& Chase, M.W. 1996. Sapindales: molecular delimitation and infraordinal groups. American Journal of Botany 83(6): 802-81 1.

GENTRY, A.H. \& Steyermark, J. 1987. A revision of Dilodendron (Sapindaceae). Annals of the Missouri Botanical Garden 74(3): 533-538.

GIULIETTI, A.M.; Menezes, N.L.; Pirani, J.R.; Meguro, M. \& Wanderley, M.G.L. 1987. Flora da Serra do Cipó, Minas Gerais: caracterização e lista das espécies. Bol. Bot. Univ. São Paulo 9: 1-151.

GUARIM NETO, G. 1985. Estudos taxonômicos em Cupania L. (Sapindaceae): as espécies brasileiras. Tese (Doutorado) apresentada ao INPA/FUA. Manaus (AM). 272p.

GUARIM NETO, G. 1993. Novas espécies de Cupania L. (Sapindaceae) para o Brasil. Eugeniana, 20: 7-15. 
HARRINGTON, M.G.; Edwards, K.J.; Johnson, S.A.; Chase, M.W. \& Gadek, P.A. 2005. Phylogenetic inference in Sapindaceae sensu lato using plastid matK and rbcL DNA sequences. Syst. Bot. 30(2): 366-382.

HARRINGTON, M.G. \& Gadek, P.A. 2009. A species well travelled - the Dodonaea viscosa (Sapindaceae) complex based on phylogenetic analyses of nuclear ribosomal ITS and ETSf sequences. Journal of Biogeography 36: 2313-2323.

HARRINGTON M.G. \& Gadek, P.A. 2010. Phylogenetics of hopbushes and pepperflowers (Dodonaea, Diplopeltis-Sapindaceae), based on nuclear ribosomal ITS and partial ETS sequences incorporating secondarystructure models. Australian Systematic Botany 23: 431-442.

JOLY, C.A. 1979. Fisiologia da germinação e aspectos taxonômicos do gênero Magonia St. Hil. (Sapindaceae). Dissertação (Mestrado) Universidade Estadual de Campinas, Instituto de Biologia. 98p.

JOLY, C.A.; Felippe, G.M. \& Melhem, T.S. 1980. Taxonomic studies in Magonia St.-Hill (Sapindaceae). Brittonia 32(3): 380-386.

MULLER, J. \& Leenhouts, P.W. 1976. A general survey of pollen types in Sapindaceae in relation to taxonomy. In: Ferguson, J.K., Muller, J. (eds.) The evolutionary significance of the exine. Linnean Soc. Symp. Ser. 1, 407-445p. London: Academic Press.

POLO, S.H.O. 2006. Estrutura e desenvolvimento de sementes de Paullinia L. (Sapindaceae). Dissertação (Mestrado) - Universidade Estadual de Campinas, Instituto de Biologia. 107p.

RADLKOFER, L. 1892-1900. Sapindaceae. In: Martius, C.F. - Flora Brasiliensis. 13: 225-679p.

RADLKOFER, L. 1933-1934. Sapindaceae. In: ENGLER, A. (Ed.), Die Naturlichen Pflanzenfamilien 98a-h, (Heft. IV.165): 1-1539p.

REITZ, R. 1980. Sapindaceae. In: Reitz, R. (Org.). Flora llustrada Catarinense. Herbario Barbosa Rodrigues, Itajai. 160p.

SOMMER, G.V. 2001. Paullinia L. (Sapindaceae): Morfologia, Taxonomia e Revisão de Paullinia sect. Phygoptiton. Tese (Doutorado)-Instituto de Biociências da Universidade de São Paulo. Departamento de Botânica. $275 p$.

SOMNER, G.V. \& Ferrucci, M.S. 2004. A new species of Cupania sect. Trigonocarpus (Sapindaceae) from Brazil. Bot. J. Linnean Soc. 146: $217-$ 221. 
SOMNER, G.V. \& Ferrucci, M.S. 2009. Sapindaceae. In: Martins, S.E., Wanderley, M.G.L., Shepherd, G.J., Giulietti, A.M. \& Melhem, T.S. (Eds.). Flora Fanerogâmica do estado de São Paulo. Instituto de Botânica, São Paulo, v. 6. 195-255p.

SOMNER, G.V.; Ferrucci, M.S.; Rosa, M.M.T. \& Coelho, R.G.L. 2009. Sapindaceae. In: Martins, S.E.; Wanderley, M.G.L.; Shepherd, G.J.; Giulietti, A.M. \& Melhem, T.S. (Eds.). Flora Fanerogâmica do estado de São Paulo. Instituto de Botânica, São Paulo, v. 6. 195-255p.

SOMNER, G.V.; Ferrucci, M.S.; Acevedo-Rodríguez, P. 2010. Sapindaceae. In: Forzza, R.C. et al. 2010. Lista de Espécies da Flora do Brasil. Jardim Botânico do Rio de Janeiro. http://floradobrasil.jbrj.gov.br/

SOLís, S. M. \& Ferrucci, M.S. 2006. Comparative leaf morpho-anatomical studies of two South American species of Cardiospermum (Sapindaceae) with special reference to adaxial domatia. Blumea, 51: 153-164.

SOUZA, C.Z. \& Lorenzi, H. 2005. Botânica Sistemática - Guia llustrado para identificação das famílias de Angiospermas da flora brasileira, baseado em APG II. Nova Odessa, SP: Instituto Plantarum. 640p.

WEST, J.G. 1984. A revision of Dodonaea Miller (Sapindaceae) in Australia. Brunonia 7: 1-194. 


\section{Discussão Geral e Conclusões}

O presente trabalho resultou em 39 espécies distribuídas em 10 gêneros. Comparando esses dados com o trabalho de Giulietti et al. (1987), onde 13 espécies em seis gêneros foram amostrados em uma listagem preliminar das plantas da Serra do Cipó, nota-se um aumento de quase $200 \%$ no número de espécies. Tal aumento pode ser atribuído a fatores como o aumento do esforço de coleta específicas para Sapindaceae nas áreas do Parque Nacional da Serra do Cipó e ao longo da rodovia MG 0-10, a ampliação da área amostrada incluindo as regiões de Santana do Pirapama, a rodovia MG 232 sentido Morro do Pilar, trecho da rodovia MG 010 após o bifurcamento Morro do Pilar-Conceição do Mato Dentro e a porção leste da Serra do Cipó (no domínio da Mata Atlântica), como também a consulta aos herbários. Todos esses fatores foram fundamentais para o enriquecimento dos resultados do presente estudo, já evidenciados por outros autores como Martins (2009), Borges (2010) e Rando (2009) nos estudos de outros grupos presentes na serra do Cipó. De forma geral, as Sapindaceae apresentam morfologia e hábito variáveis, relacionados à distribuição, habitats ou plasticidade fenotípica apresentada por alguns espécimes, sendo essencial a consulta a um número considerável de materiais herborizados e no campo, o contato com especialistas da área e materiais tipos também foram importantes para a correta identificação e circunscrição das plantas, já que gêneros como Cupania e Matayba, Cardiospermum, Paullinia e Serjania em estado vegetativo são facilmente confundidos entre si.

Caracteres como hábito, indumento, tipo de folha, número, formato e margem dos folíolos, domácias, tipos de inflorescências, formato do apêndice petalóide e tipos de frutos, mostraram-se essenciais para a distinção das espécies dada a variabiidade e constância entre os táxons. Em 
relação ao hábito, 24 espécies (62\%) são trepadeiras, todas pertencentes à tribo Paullineae, enquanto as arbóreas e arbustivas representaram 15 espécies (38\%). Serjania lethalis coletada nos campos graminosos na área do PARNA Serra do Cipó, por não possuir outras espécies para apoiar apresenta um comportamento de moita, o que Acevedo-Rodriguez (1993), chama de "arching shrubs or trailing vines" (algo como arbustos arqueados ou trepadeiras rasteiras).

Algumas particularidades foram encontradas para alguns gêneros destacando o tipo de folha em Dodonaea, o crescimento anômalo do caule em algumas espécies de Serjania, o arilo carnoso e frutos cápsulas septífragas em Paullinia, fruto cápsula septífraga com lóculos inflados em Cardiospermum, as folhas bipinadas em Dilodendron, as folhas 3-folioladas em Allophylus, as flores zigomorfas e pétalas sem apêndice basal em Magonia, os tipos de folíolos e frutos em Cupania, proeminência e tipos de venação e domácias nos folíolos em Matayba e flor e número e formato dos folíolos em Toulicia laevigata.

Dentre os gêneros com maior diversidade estão Serjania com 18 espécies, seguido de Matayba e Paullinia cada um com cinco espécies e Cupania com quatro espécies. Em compensação Cardiospermum, Dilodendron, Dodonaea, Magonia e Toulicia possuem apenas uma espécie, sendo Magonia um gênero monoespecífico, sul-americano e Dilodendron e Dodonaea possuem uma única espécie ocorrente no Brasil e de ampla distribuição.

Quanto à distribuição geográfica, as espécies foram divididas de acordo com a ocorrência nas regiões relacionadas às porções oeste e leste da Serra do Espinhaço, grosso modo Domínios do Cerrado e Mata Atlântica respectivamente, seguido das preferências ambientais e do gradiente altitudinal (tabela 1). Das 39 espécies de Sapindaceae encontradas na região, $92 \%$ foram encontradas na porção oeste; $28 \%$ na porção leste e $18 \%$ espécies foram comuns em ambas as porções da Serra do Cipó. Estes números podem estar relacionados principalmente ao esforço de coleta, já que o porção oeste concentrou a maioria das expedições de coleta, além 
de ser o trecho escolhido inicialmente por Giullieti et al. (1987) na fase inicial do projeto de levantamento da flora da região.

Das espécies ocorrentes na Serra do Cipó, 19 são endêmicas do Brasil. Cupania moraesiana, Matayba mollis e Matayba stenodictya são endêmicas do estado de Minas Gerais. Allophylus petiolulatus, Matayba intermedia e Serjania tripleuria no presente trabalho, são novos registros de ocorrência para o estado de Minas Gerais. A. petiolulatus e M. intermedia foram encontradas na Mata Estacional Semidecídua na porção leste da Serra do Cipó, anteriormente conhecidas para a região sudeste nos estados de São Paulo e Rio de Janeiro em Domínio de Mata Atlântica (Somner et al., 2010). S. tripleuria foi encontrada em afloramento rochoso em Floresta estacional decídua no Morro da Pedreira, anteriormente conhecida para os estados de Mato Grosso do Sul e São Paulo, nos Domínios do Pantanal e Mata Atlântica (Somner et al., 2010).

Embora a Serra do Cipó abrigue algumas espécies pontualmente endêmicas, nenhuma Sapindaceae é endêmica da região, apesar disso, muitas espécies foram encontradas restritas no local:

- 6 espécies na APA Morro da Pedreira, entre elas Serjania tristis, anteriormente conhecida apenas para regiões mais úmidas;

- 1 espécie, Matayba stenodictya, nos dois capões de mata, situados próximos a bifurcação Morro do Pilar-Conceição do Mato Dentro, e 1 capão próximo a estátua do Juquinha, como novo registro e praticamente redescobrimento dessa espécie, já que o seu último registro de coleta são os materiais sintipos de (Magalhães-Gomes 488, Ouro Preto e Schwacke 8746, Serra de Antonio), citados por Radlkofer (1892-1900);

- 4 espécies no município de Santana de Pirapama;

- 1 espécie nas margens do Rio Santo Antônio e

- 3 espécies na Mata Estacional Semidecídua na porção leste.

O que torna a Serra do Cipó importante para a conservação dessas espécies. Quanto ao gradiente altitudinal, a maioria das espécies (20) foram encontradas abaixo de 1000m.s.m.; (5) acima de 1000m.s.m. e (9) em ambas atitudes. 
Entre as preferências vegetacionais foram encontradas, 18 espécies em áreas de mata ciliar e de galeria e capões; 3 espécies em áreas de transição cerrado-campo rupestre; 9 espécies em cerrado; 9 espécies em Floresta Estacional decidual da APA Morro da Pedreira e 11 espécies em Mata Estacional Semidecídua.

Serjania lethalis além de ser encontrada em quase todos os ambientes, na área do PARNA possui um crescimento desenfreado, se tornando-se invasora principalmente nas regiões perturbadas ou com influência antrópica.

Cupania ludowigii e Toulicia laevigata, embora encontrados nas duas porções (leste e oeste) possuem apenas um indivíduo cada no lado oeste, situados acima de 1000m.s.m., sendo mais representativas na porção leste. De acordo (Somner et al., 2010), ambas espécies pertencem ao domínio da Mata Atlântica e segundo (Somner \& Ferrucci, 2004), C. ludowiguii pode ser também encontrada nas matas de galeria incluídas na vegetação de campos rupestres, em solos hidromórficos pedregosos a uma altitude de 6601100 m.s.m., fato evidenciado para o indivíduo presente na porção oeste.

Dessa maneira, as espécies da família Sapindaceae na Serra do Cipó foram encontradas nas áreas de Mata Atlântica e Cerrado, sendo menos expressivas nos campos rupestres, o que contrasta com a grande maioria das famílias da Serra, onde geralmente a maioria das espécies ocorre em campos rupestres (Giulietti et al., 1987). Do total de espécies, ca. 59\% habitando preferencialmente locais úmidos e sombreados e ca. $54 \%$ habitando áreas secas.

Entre os novos dados apresentados pode-se ainda citar a primeira ocorrência de Cupania moraesiana em Mata Estacional Semidecídua, anteriormente restrita de área de cerrado no estado de Minas Gerais segundo (Guarim Neto, 1993; Somner et al., 2010). U Uma comparação do número de espécies arbóreas ocorrentes na Serra do Cipó da família Sapindaceae com o estudo de Kamino et al. (2008), os quais organizaram uma lista de espécies arbóreas registradas em dezoito outras áreas da Cadeia do Espinhaço, em Minas Gerais e Bahia demonstra que a Serra do 
Cipó e Mariana possuem o maior número de espécies 115 e 8, respectivamente), seguidas da Chapada de São Domingos e Ouro Preto (6), Catolés e Santa Bárbara (5), Grão Mogol, Diamantina, Belo Horizonte e Nova Lima (4), Catas Altas da Norvega (3) e Mucugê, Palmeiras e Jacobina (2) e Morro do Chapéu e Gentio do Ouro (0). Entre as áreas analisadas, a Chapada de São Domingos, Nova Lima, Mariana e Ouro Preto apresentam o maior número de espécies em comum com a Serra do Cipó (8). Oito espécies ocorrentes na Serra do Cipó, não foram registradas nessas outras áreas (tabela 2).

O presente trabalho contribui para o conhecimento da diversidade de espécies da família Sapindaceae na área e para o aumento da coleção Flora da Serra do Cipó, produzindo dados que podem justificar a preservação da área e que ressaltam a importância dos estudos florísticos regionais. 


\section{Resumo}

Este trabalho vem contribuir com o projeto "Flora da Serra do Cipó, Minas Gerais, Brasil", através do levantamento e estudo taxonômico da família Sapindaceae. A família Sapindaceae compreende ca. 1756 espécies e 136 gêneros, sendo predominantemente pantropical. Caracteriza-se pelas folhas compostas pinadas, flores com disco nectarífero extraestaminal, apêndice petalífero, estames 8 ou menos, sementes frequentemente ariladas e embrião curvo com dobra na testa. O levantamento das espécies foi realizado baseando-se nas coleções da Serra do Cipó, visitas aos herbários, expedições de campo e consultas bibliográficas. Na Serra do Cipó foram encontradas 39 espécies, pertencentes a 10 gêneros: Allophylus (2 spp.), Cardiospermum (1 sp.), Cupania (4 spp.), Dilodendron (1 sp.), Dodonaea ( 1sp.), Magonia (1 sp.), Matayba (5 spp.), Paullinia (5 spp.), Serjania (18 spp.) e Toulicia (1 sp.). Este número de espécies é ca. 200\% maior do que o levantamento preliminar da flora realizado. As espécies trepadeiras (24) são a maioria, as arbóreas e arbustivas representaram 15 espécies. Serjania foi o gênero com maior diversidade, seguido de Matayba e Paullinia. Entre os novos dados temos: - a primeira ocorrência de Cupania moraesiana em Mata Estacional Semidecídua; - Allophylus petiolulatus e Matayba intermedia como novos registros de ocorrência para o estado de Minas Gerais e além de novo registro, o redescobrimento de Matayba stenodictya. As espécies de Sapindaceae ocorrentes na Serra do Cipó foram encontradas em áreas de Mata Atlântica e Cerrado, menos expressivas nos campos rupestres. Chaves de identificação, descrição morfológica, comentários sobre distribuição geográfica e fenologia, ilustrações e fotos das espécies estudadas são apresentadas. 


\section{Abstract}

This work contributes to a project "Flora da Serra do Cipó, Minas Gerais, Brazil, being a survey and a taxonomic study of the family Sapindaceae in that area. The family Sapindaceae includes about 1756 species and 136 genera, predominantly pantropical. The family is characterized by its pinnately compound leaves, flowers with a extraestaminal nectar disk, petals with basal appendages, stamens 8 or fewer, seeds often with an aril-like coat and embryo curved and with deep fold in seed coat. The survey of the species was carried out based on collections from Serra do Cipó, visits to herbaria, field work and bibliographical consultations. In that area 39 species were found, belonging to 10 genera: Allophylus (2 spp.), Cardiospermum (1 sp.), Cupania (4 spp.), Dilodendron (1 sp.), Dodonaea ( 1sp.), Magonia (1 sp.), Matayba (5 spp.), Paullinia (5 spp.), Serjania (18 spp.) and Toulicia (1 sp.). This number of species is ca. $200 \%$ bigger than that found in a preliminar list. Climbers species (24) are the larger group, with 15 species of trees or shrubs. Serjania was the genus with the highest diversity, followed by Matayba and Paullinia. Among the results are the first occurrence of Cupania moraesiana in semi-deciduous forest; - Allophylus petiolulatus and Matayba intermedia as new records of occurrence for the state of Minas Gerais and the rediscovery of Matayba stenodictya. The species of Sapindaceae occurring at Serra of Cipó were found in áreas of Atlantic Forest and Cerrado, and less expressive at the rocky fields. Identification keys, morphological descriptions, comments on geographic distribution and phenology, illustrations and pictures about species studied are provided. 
Anexos e Apêndices 
Tabela 1 - Relação das espécies de Sapindaceae registradas nas principais fitofísionomias, porções Leste ou Oeste e gradiente altitudinal na Serra do Cipó. As espécies estão organizadas em ordem alfabética e seguidas do registro de ocorrência $(\bullet)$. As fitofisionomias, as porções leste e oeste e o gradiente altitudinal são identificadas pelos códigos: $\mathrm{Ce}=\mathrm{Cerrado}$; $\mathrm{Ma}=\mathrm{Matas} ; \mathrm{Cr}=\mathrm{Campo}$ rupestre; $\mathrm{Afl} \mathrm{roch}=\mathrm{Afloramento}$ rochoso; $\mathrm{Pç} \mathrm{L}=\mathrm{Porção} \mathrm{leste;}$ $\mathrm{Pç} \mathrm{O}=$ Porção oeste; FED=Floresta estacional decidual; Alt. m.s.m.=Altitude.

\begin{tabular}{|c|c|c|c|c|c|c|c|c|}
\hline Espécies/Fitofisionomias & $\ddot{\theta}$ & $\sum^{\pi}$ & نَ & $=\frac{5}{0}$ & en & $\begin{array}{l}0 \\
\text { un } \\
=\end{array}$ & 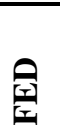 & 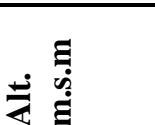 \\
\hline \multicolumn{9}{|l|}{ SAPINDACEAE } \\
\hline Allophylus petiolulatus (A.St.-Hil. et. al.) & & & & & $\bullet$ & & & 1035 \\
\hline Allophylus sericeus Radlk. & & & & - & & - & - & 976 \\
\hline Cardiospermum grandiflorum $\mathrm{Sw}$. & & $\bullet$ & & & & - & & $935-976$ \\
\hline Cupania ludowigii Somner \& Ferrucci & & $\bullet$ & & & $\bullet$ & - & & 708,1358 \\
\hline Cupania moraesiana Guarim & $\bullet$ & & & & $\bullet$ & $\bullet$ & & 749 \\
\hline Cupania paniculata Cambess. & $\bullet$ & & & & & $\bullet$ & & 704 \\
\hline Cupania vernalis Cambess. & & $\bullet$ & & $\bullet$ & $\bullet$ & $\bullet$ & & $745-1318$ \\
\hline Dilodendron bipinnatum Radlk. & & $\bullet$ & & & & $\bullet$ & $\bullet$ & $633-865$ \\
\hline Dodonaea viscosa Jacq. & & $\bullet$ & & & & $\bullet$ & & \\
\hline Magonia pubescens A.St.-Hil. & - & & & & & $\bullet$ & & $673-841$ \\
\hline Matayba guianensis Aubl. & & & & $\bullet$ & & $\bullet$ & & $774-877$ \\
\hline Matayba intermedia Radlk. & - & & & & $\bullet$ & & & 1033 \\
\hline Matayba juglandifolia (Cambess.) Radlk. & & - & & & & - & & \\
\hline Matayba mollis Radlk. & - & & & & & - & & $600-817$ \\
\hline Matayba stenodictya Radlk. & & $\bullet$ & & & & - & & 1320,135 \\
\hline Paullinia carpopoda Cambess. & & - & & $\bullet$ & - & - & $\bullet$ & $700-1355$ \\
\hline Paullinia meliifolia Juss. & & & & $\bullet$ & & - & $\bullet$ & $865-979$ \\
\hline Paullinia racemosa Wawra & & & & & & $\bullet$ & & \\
\hline Paullinia spicata Benth. & & $\bullet$ & & & & - & & 650 \\
\hline Paullinia trigonia Vell. & & & & & - & & & $708-1033$ \\
\hline Serjania acutidentata Radlk. & $\bullet$ & $\bullet$ & & & $\bullet$ & $\bullet$ & & $700-1010$ \\
\hline Serjania caracasana (Jacq.) Willd. & & $\bullet$ & & - & & $\bullet$ & $\bullet$ & $865-976$ \\
\hline Serjania deflexa Gardner & & & & & & - & & 1342 \\
\hline Serjania erecta Radlk. & $\bullet$ & & & & & - & & $686-1090$ \\
\hline Serjania lethalis A.St.-Hil. & $\bullet$ & $\bullet$ & & $\bullet$ & & $\bullet$ & $\bullet$ & $762-1198$ \\
\hline
\end{tabular}


continuação...

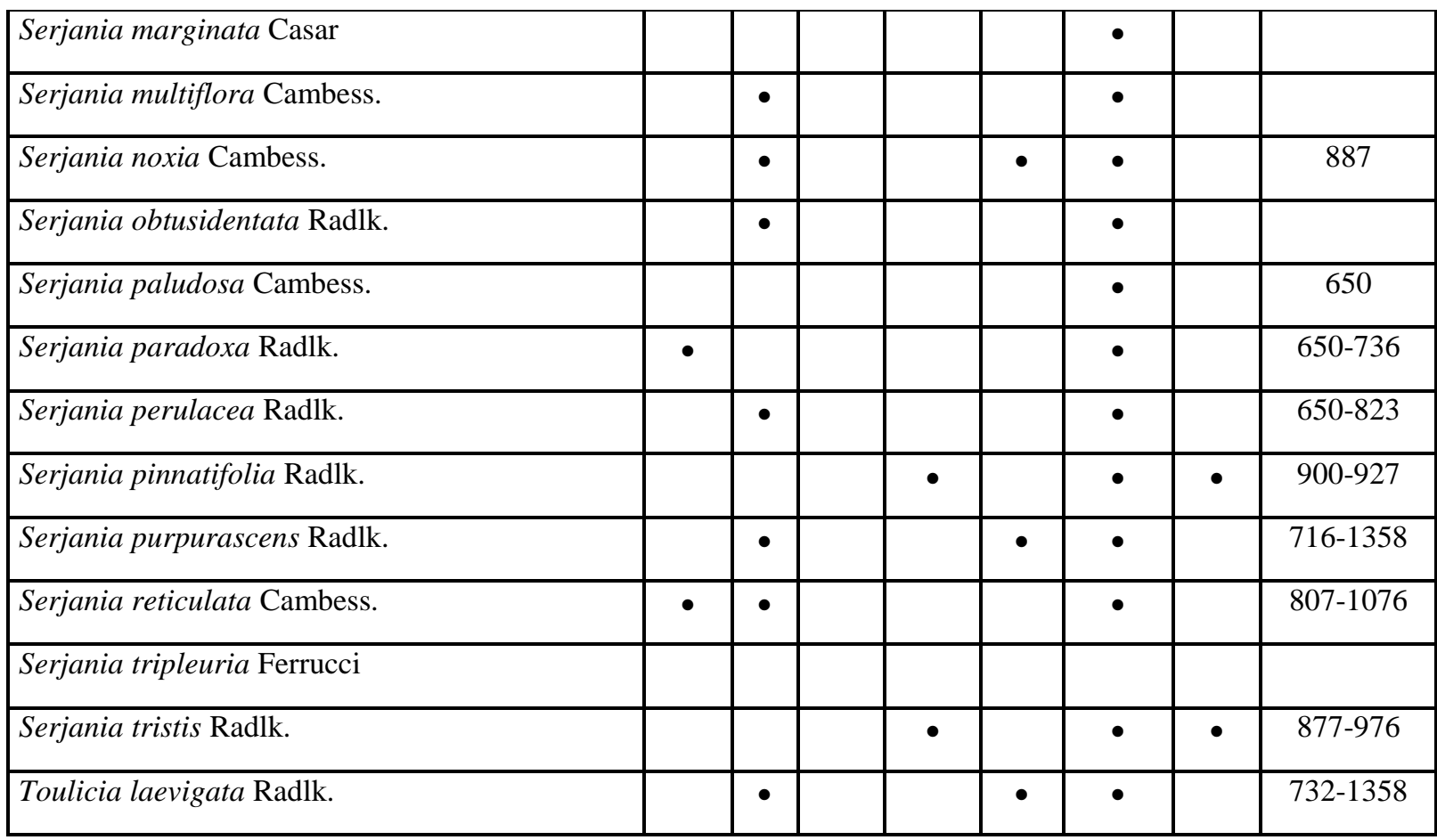


Tabela 2. Relação das espécies arbóreas de Sapindaceae registradas nas 18 áreas de formações florestais inventariadas no Complexo do Espinhaço em Minas Gerais e Bahia. As espécies estão organizadas em ordem alfabética e seguidas do registro de ocorrência (•). As áreas de florestas são identificadas pelos códigos: morr=Morro do Chapéu; gent $=$ Gentio do Ouro; jaco=Jacobina; cato=Catolés; palm=Palmeiras; mucu=Mucugê; grao=Grão Mogol; diam=Diamantina; cipo=Serra do Cipó; leme=Leme do Prado; chap=Chapada de São Domingos; barb=Santa Bárbara; belo=Belo Horizonte; cong=Congonhas do Campo; novl=Nova Lima; mari=Mariana; cata $=$ Catas Altas da Noruega e ouro=Ouro Preto. Modificado de Kamino et al. 2008

\begin{tabular}{|c|c|c|c|c|c|c|c|c|c|c|c|c|c|c|c|c|c|c|}
\hline \multirow[b]{2}{*}{$\begin{array}{l}\text { ESPÉCIES/FORMAÇÕES } \\
\text { FLORESTAIS }\end{array}$} & \multicolumn{6}{|c|}{ BAHIA } & \multicolumn{12}{|c|}{ MINAS GERAIS } \\
\hline & 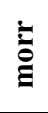 & Ё & $\underset{\mathscr{E}}{\stackrel{\mathscr{E}}{\pi}}$ & 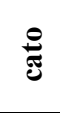 & 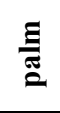 & $\stackrel{\Xi}{\Xi}$ & 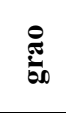 & 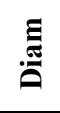 & $\stackrel{2}{\circ}$ & $\stackrel{\Xi}{\Xi}$ & $\frac{2}{\frac{\pi}{\pi}}$ & : & $\stackrel{0}{\square}$ & $\stackrel{\infty}{\bar{\Xi}}$ & $\bar{z}$ & : & Е્ّ & $\stackrel{0}{0}$ \\
\hline \multicolumn{19}{|l|}{ Sapindaceae } \\
\hline $\begin{array}{l}\text { Allophylus edulis (A.St.-Hil. } \\
\text { et al.) Radlk. }\end{array}$ & & & & & & & - & & & & $\bullet$ & & & $\bullet$ & & - & & \\
\hline $\begin{array}{l}\text { Allophylus petiolulatus } \\
\text { Radlk. }\end{array}$ & & & & & & & & & $\bullet$ & & & & & & & $\bullet$ & & \\
\hline Allophylus racemosus $\mathrm{Sw}$. & & & & & & & & & & & & & & & & - & & \\
\hline $\begin{array}{l}\text { Allophylus sericeus } \\
\text { (Cambess.) Radlk. }\end{array}$ & & & & & & & & & $\bullet$ & & & & & & & $\bullet$ & & \\
\hline $\begin{array}{l}\text { Cupania inaequilatera } \\
\text { Guarim }\end{array}$ & & & & & & & & & $\bullet$ & & & & & & $\bullet$ & & & \\
\hline $\begin{array}{l}\text { Cupania ludowigii Somner } \\
\text { \& Ferrucci }\end{array}$ & & & & & & & $\bullet$ & • & $\bullet$ & $\bullet$ & $\bullet$ & $\bullet$ & & $\bullet$ & & & $\bullet$ & $\bullet$ \\
\hline $\begin{array}{l}\text { Cupania moraesiana } \\
\text { Guarim }\end{array}$ & & & & & & & & $\bullet$ & $\bullet$ & & & & & & & & & \\
\hline $\begin{array}{l}\text { Cupania paniculata } \\
\text { Cambess. }\end{array}$ & & & & $\bullet$ & $\bullet$ & - & & & $\bullet$ & & - & & & & & & & \\
\hline $\begin{array}{l}\text { Cupania racemosa (Vell.) } \\
\text { Radlk. }\end{array}$ & & & & & & & & & & & & & & & & & $\bullet$ & \\
\hline $\begin{array}{l}\text { Cupania radlkoferi Acev.- } \\
\text { Rodr. }\end{array}$ & & & & & & & & & & & & $\bullet$ & & & & & & \\
\hline Cupania rigida Radlk. & & & $\bullet$ & $\bullet$ & & & & & $\bullet$ & & & & & & & & & \\
\hline Cupania vernalis Cambess. & & & & & & & & & • & & & - & $\bullet$ & $\bullet$ & - & - & & - \\
\hline $\begin{array}{l}\text { Cupania zanthoxyloides } \\
\text { Cambess. }\end{array}$ & & & & & & & & & & & & & $\bullet$ & $\bullet$ & & & & \\
\hline $\begin{array}{l}\text { Diatenopteryx grazielae Vaz } \\
\text { \& Andreata }\end{array}$ & & & & $\bullet$ & & & & & & & & & & & & & & \\
\hline $\begin{array}{l}\text { Dilodendron bipinnatum } \\
\text { Radlk. }\end{array}$ & & & & & & & & & $\bullet$ & $\bullet$ & & & & & & & & \\
\hline Dodonaea viscosa Jacq. & & & $\bullet$ & $\bullet$ & $\bullet$ & $\bullet$ & & & $\bullet$ & & & & & & & & & \\
\hline $\begin{array}{l}\text { Magonia pubescens A. St.- } \\
\text { Hil. }\end{array}$ & & & & $\bullet$ & & & & & • & & & & & & & & & \\
\hline Matayba guianensis Aubl. & & & & • & & & & & $\bullet$ & & & & & & & & & \\
\hline $\begin{array}{l}\text { Matayba heterophylla } \\
\text { (Mart.) Radlk. }\end{array}$ & & & & & & & $\bullet$ & & & & & & & & & & & \\
\hline Matayba intermedia Radlk. & & & & & & & & & - & & & & & & & & & \\
\hline $\begin{array}{l}\text { Matayba juglandifolia } \\
\text { (Cambess.) Radlk. }\end{array}$ & & & & & & & & & • & & & & $\bullet$ & & $\bullet$ & $\bullet$ & $\bullet$ & $\bullet$ \\
\hline Matayba marginata Radlk. & & & & & & & $\bullet$ & $\bullet$ & & & $\bullet$ & & & & & & & $\bullet$ \\
\hline Matayba mollis Radlk. & & & & & & & & & $\bullet$ & $\bullet$ & $\bullet$ & $\bullet$ & $\bullet$ & & $\bullet$ & $\bullet$ & & $\bullet$ \\
\hline Matayba punctata Radlk. & & & & & & & & $\bullet$ & & & & & & & & & & $\bullet$ \\
\hline Matayba stenodictya Radlk. & & & & & & & & - & $\bullet$ & & & & & & & & & \\
\hline Toulicia laevigata Radlk. & & & & & & & & & - & & - & & & & & & & \\
\hline
\end{tabular}



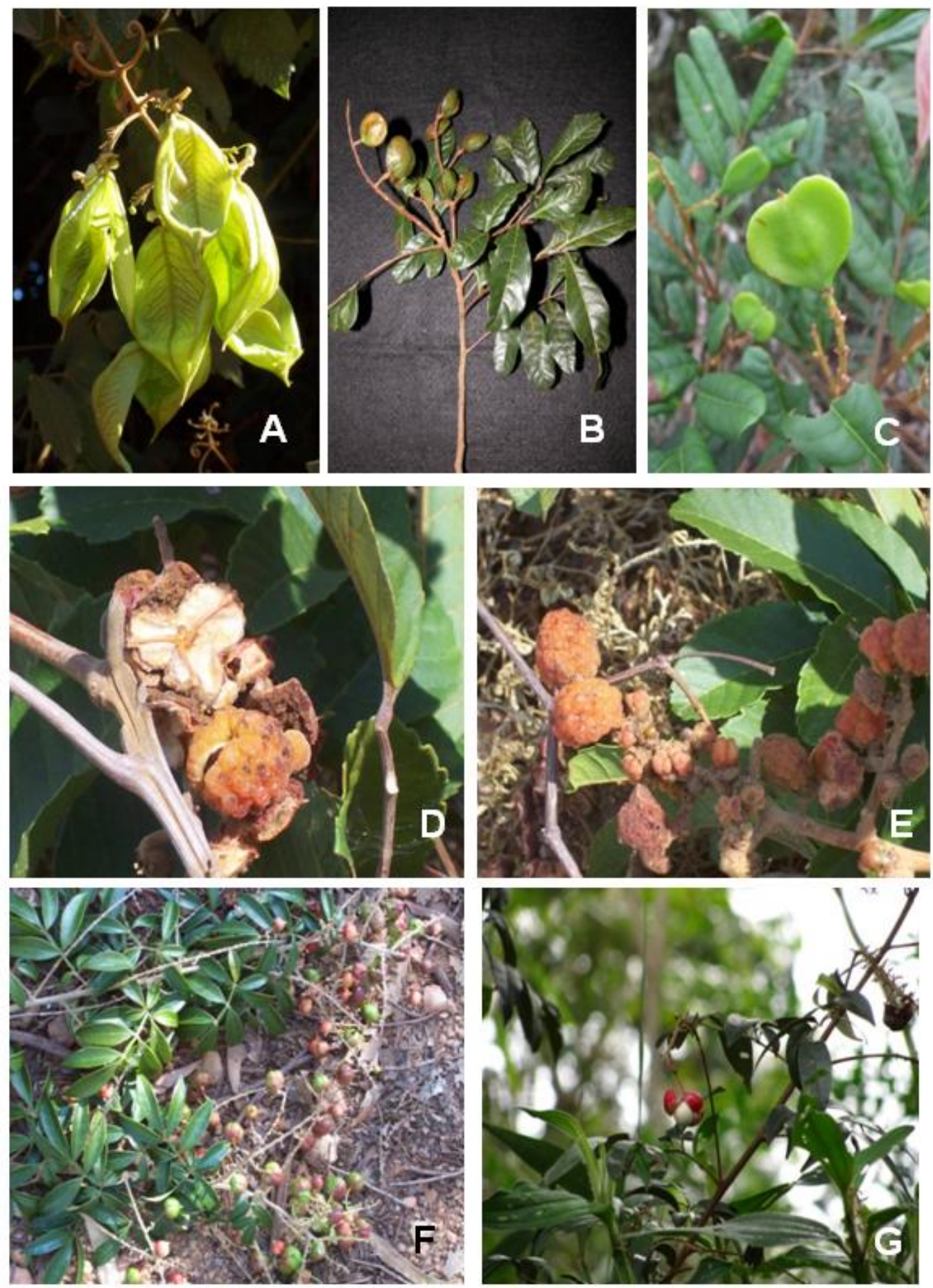

Figura 4- Espécies de Sapindaceae na Serra do Cipó. A. Cardiospermum grandiflorum, fruto. B-C Cupania ludowigii, B. ramo com fruto maduro, C. ramo com fruto jovem. D-E. Cupania vernalis, frutos. F-G. Paulinia carpopoda, F. ram os frutíf eros, G. fruto aberto mostrando o arilo. Fotos: A, C-G; K.F. Silva; B: M. Groppo. 


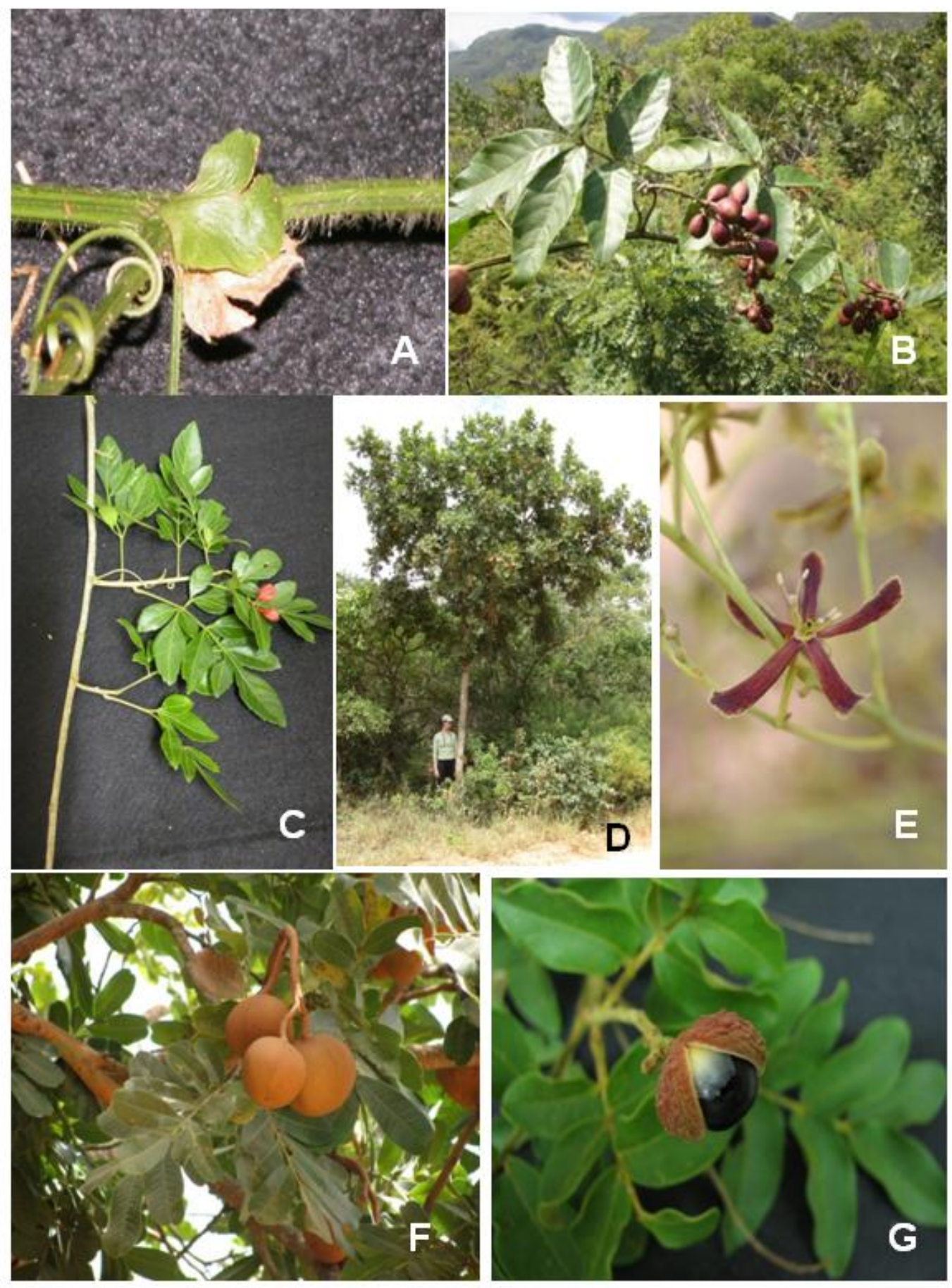

Figura 5- Espécies de Sapindaceae na Serra do Cipó. A. Paullinia melijfolia, estípula foliácea ou cuneiform e. B. Paullinia spicata, ramo frutífero. C. Paulinia trigonia, ram o frutífero. D-F. Magonia pubescens, D. Hábito, E. flor fem oum asc, F. fruto. G. Mataybamollis, fruto. Fotos: A, C: M. Groppo; B: R. Winkworth; D-G: K.F. Silva. 

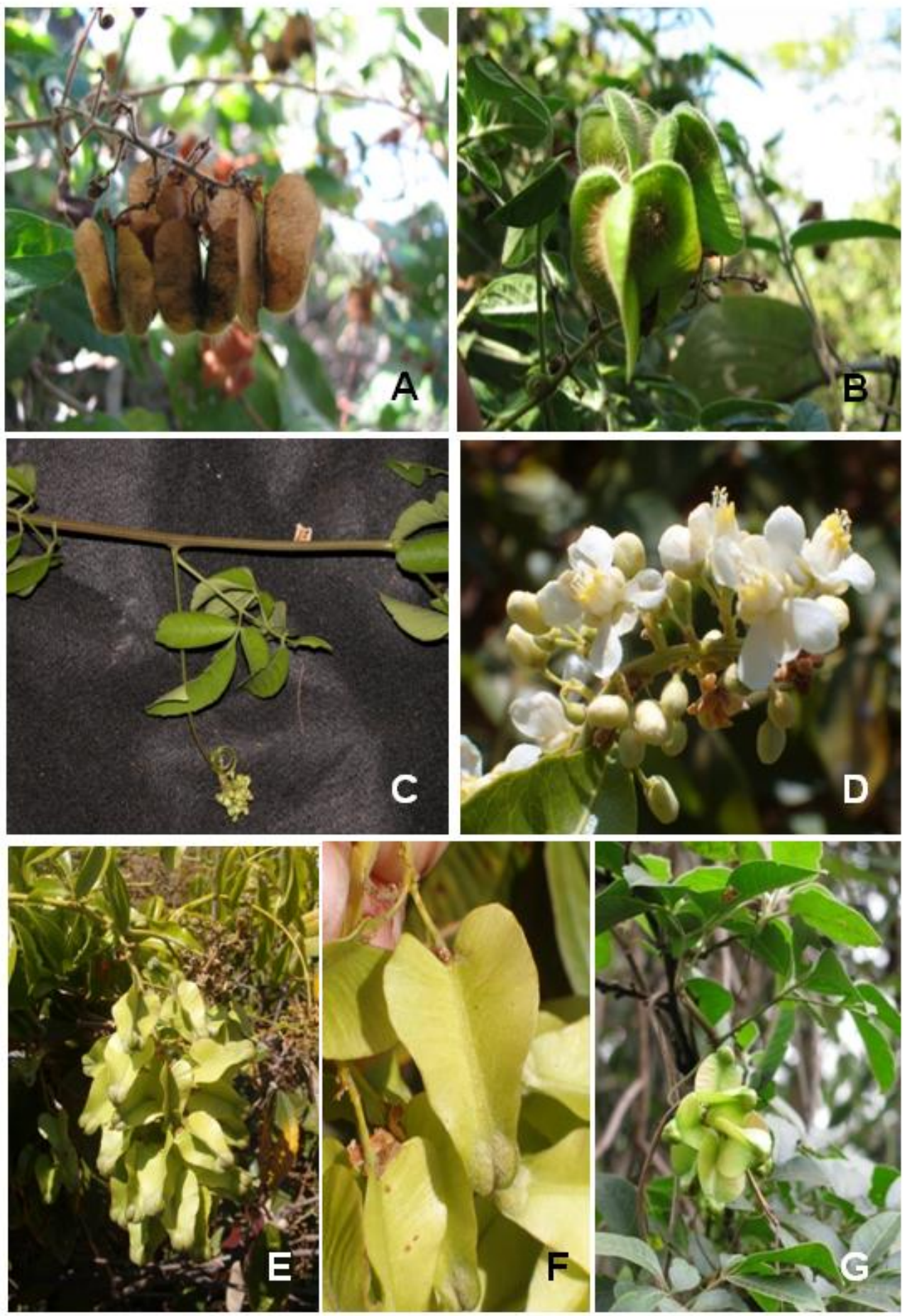

Figura 6- Espécies de Sapindaceae na Serra do Cipó. A-B. Serjania acoma, A. fruto maduro, B fruto jovem. C. Serjania caracasana, ramo e inflorescência em botão. D-F. Serjania lethalis, D flor, E-F. fruto.G. Serjania noxia, ram of futifero.

Fotos: A-C, G: K.F. Silva; D-F: M. Groppo. 

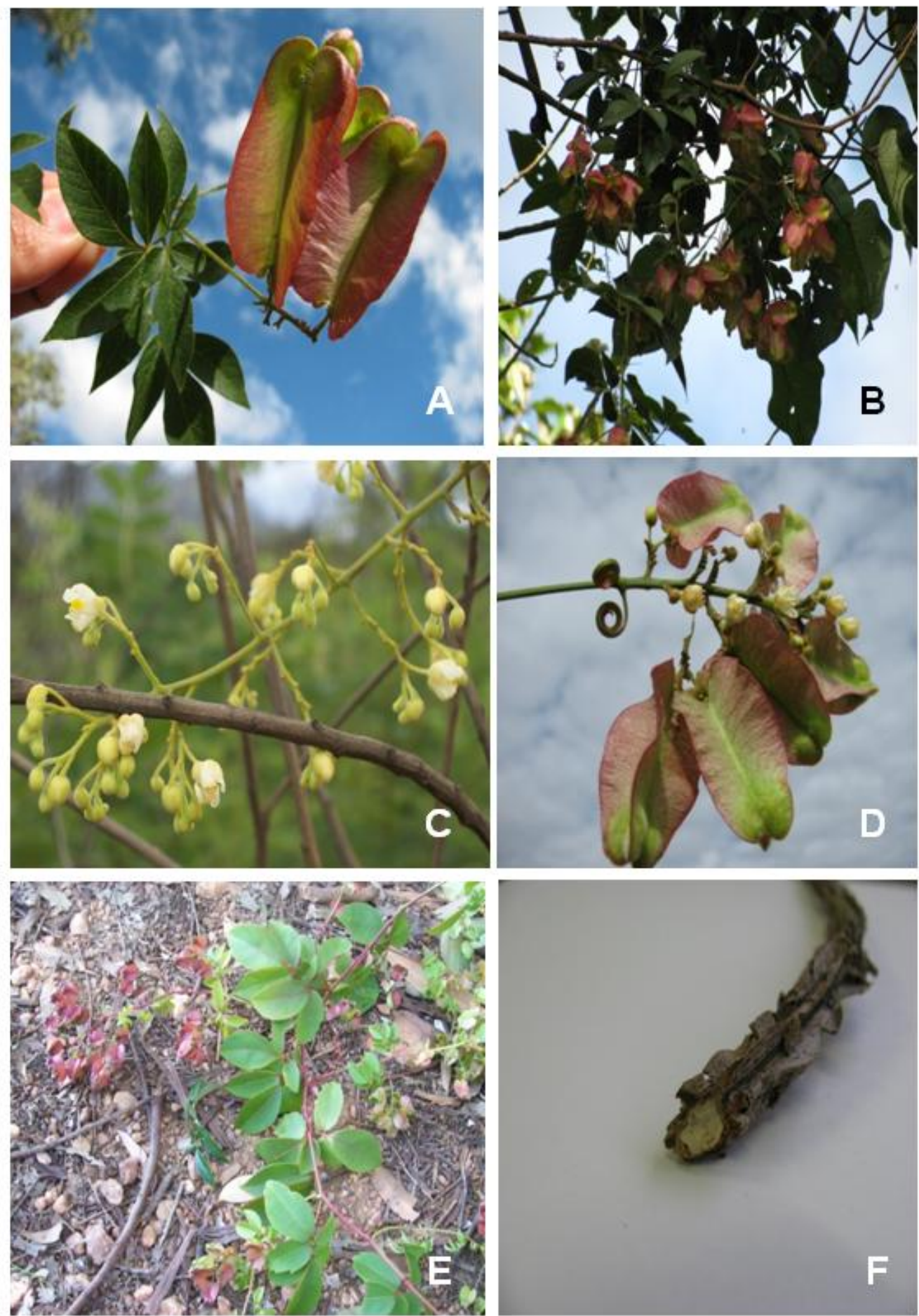

Figura 7- Espécies de Sapindaceae na Serra do Cipó. A-B. Serjania deflexa, ramo frutifero. C-D. Serjaria paradoxa, C. inflorescência, D. frutos. F. Serjania reticulata, ramo frutífero. G. Serjania tristis, caule, corte transversal

Fotos: A-G: K.F. Silva. 

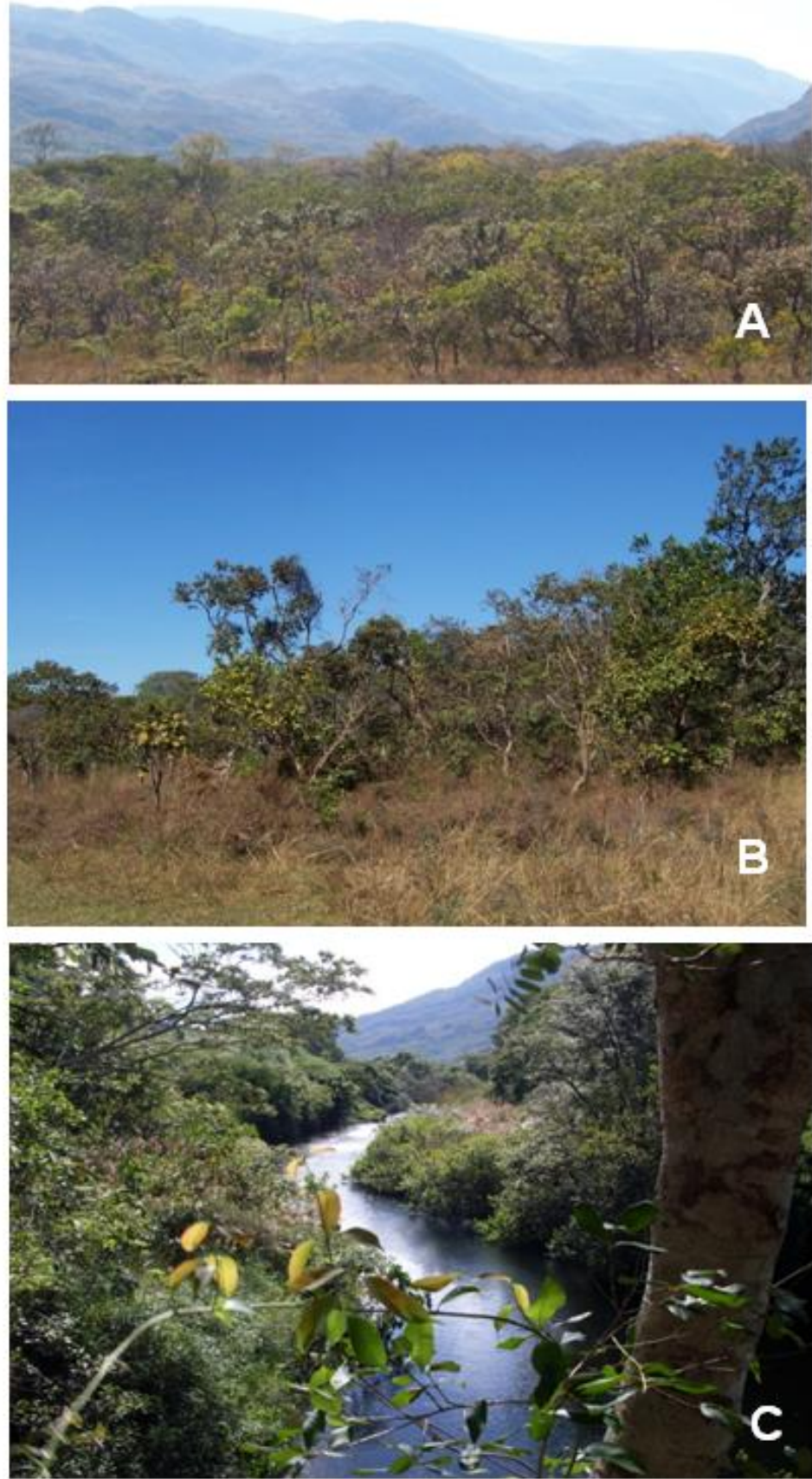

Figura 8- Localidades de coleta. A-B. Parque Nacional da Serra do Cipó, Vale dasBandeirinhas. C. m ata ciliar na margem do Rio Cipó. Fotos: A: K.F. Silva; B: T.P. Martins 

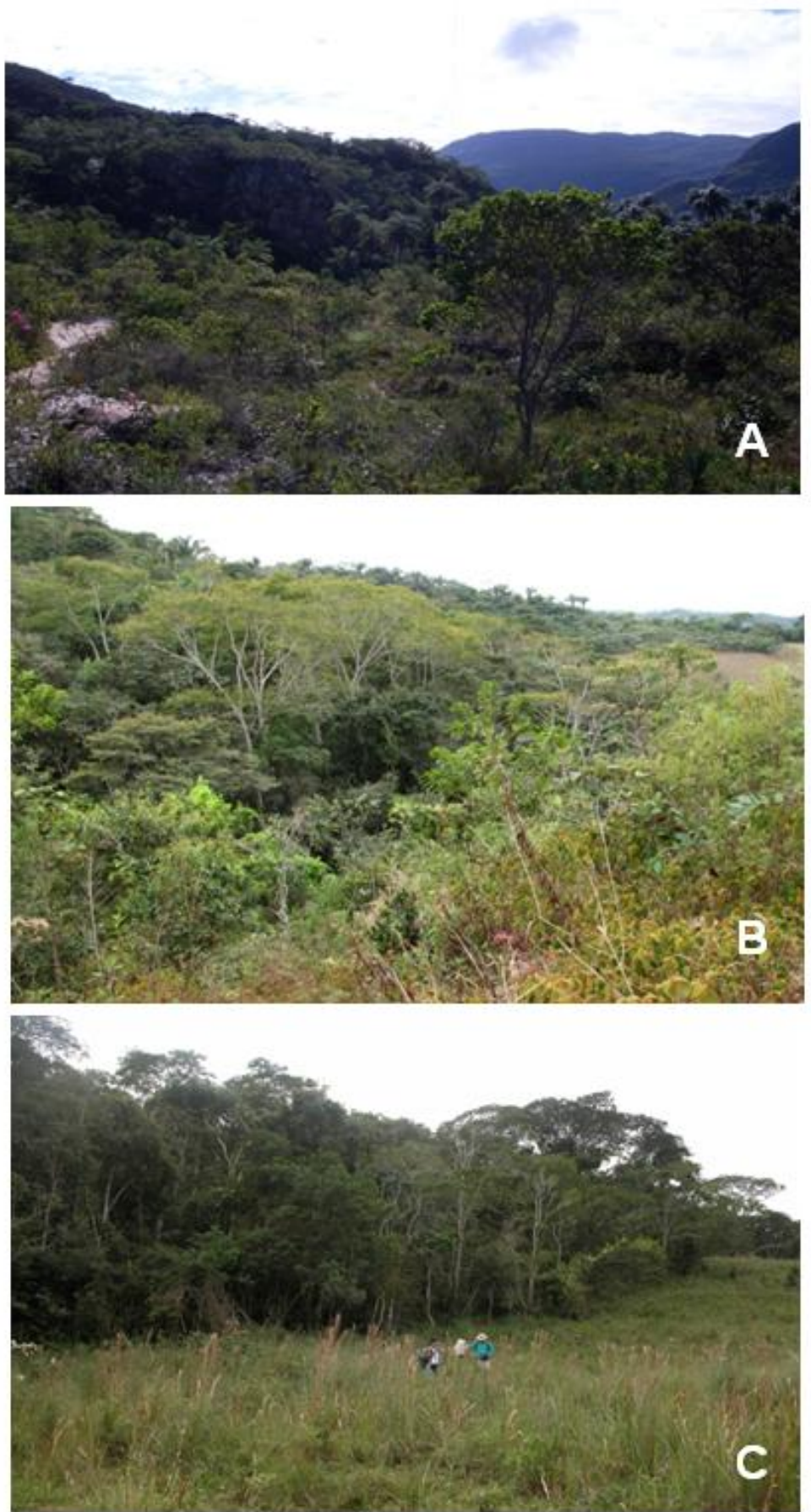

Figura 9- Localidades de coleta. A. Parque Nacional da Serra do Cipó, Vale do Ribeirão Bocaina. B. Mata na trilha para o Rio Preto de Cima. C. Mata Estaciona1Semidecídua em Santana do Rio Preto (Cabeça de B oi). Fotos: A, B: K.F. Silva; C: M. Groppo. 

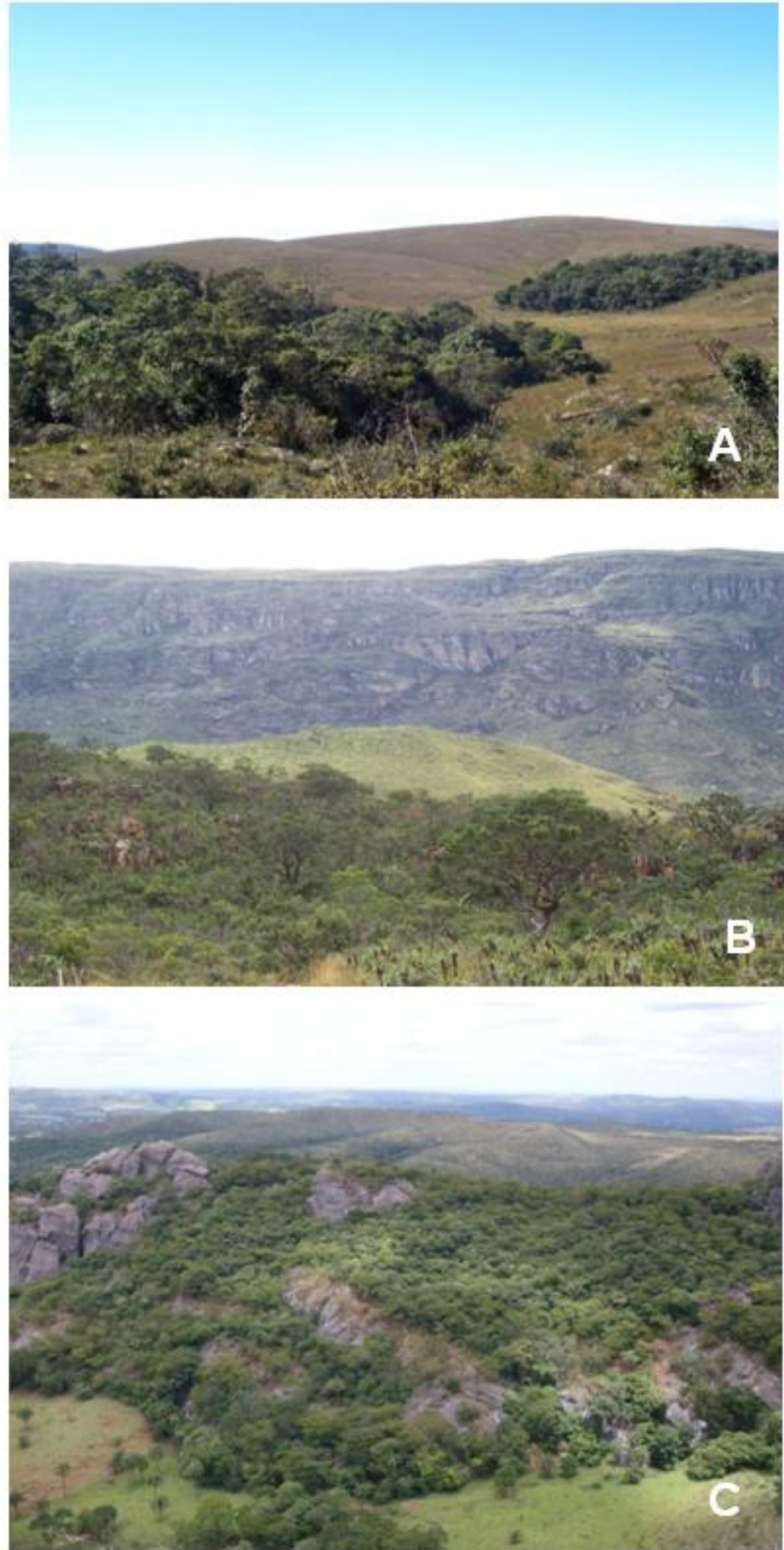

Figura 10- Localidades de coleta. A. Capões de mata no Km 130 da rodovia MG-010. B. Santana de Pirapam a.C. APA Morro da Pedreira.

Fotos: K.F. Silva 